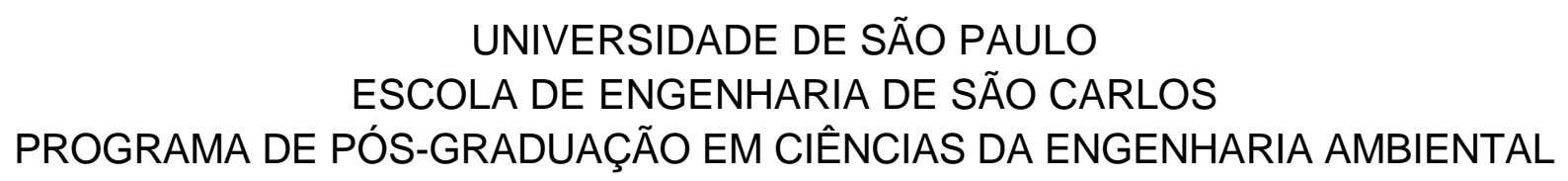

Mayra Rodrigues Silva

\title{
GESTÃO DE EMBALAGENS VAZIAS DE AGROTÓXICOS - LOGÍSTICA REVERSA EM PEQUENOS MUNICÍPIOS BRASILEIROS: O CASO DO MUNICÍPIO DE BOM REPOUSO, MG.
}



Gestão de embalagens vazias de agrotóxicos Logística Reversa em pequenos municípios brasileiros: o caso do município de Bom Repouso, MG.

Dissertação apresentada ao Programa de Pós-graduação em Ciências da Engenharia Ambiental da Universidade de São Paulo para obtenção do título de Mestre em Ciências da Engenharia Ambiental.

Orientadora: Dra. Maria Edna Tenório Nunes 
AUTORIZO A REPRODUÇÃO TOTAL OU PARCIAL DESTE TRABALHO, POR QUALQUER MEIO CONVENCIONAL OU ELETRÔNICO, PARA FINS DE ESTUDO E PESQUISA, DESDE QUE CITADA A FONTE.

Silva, Mayra Rodrigues

Gestão de embalagens vazias de agrotóxicos -

logística reversa em pequenos municípios brasileiros :

- caso do município de Bom Repouso, MG / Mayra

Rodrigues Silva; orientadora Maria Edna Tenório Nunes. São Carlos, 2016.

Dissertação (Mestrado) - Programa de Pós-Graduação em Ciências da Engenharia Ambiental e Área de Concentração em Ciências da Engenharia Ambiental -Escola de Engenharia de São Carlos da Universidade de São Paulo, 2016.

1. Gestão e gerenciamento de resíduos sólidos. 2 . Embalagens vazias de agrotóxicos. 3. Logística reversa. 4. Municípios de pequeno porte. I. Título. 


\section{FOLHA DE JULGAMENTO}

Candidata: Bacharela e Licenciada MAYRA RODRIGUES SILVA.

Título da dissertação: "Gestão de embalagens vazias de agrotóxicos - logística reserva em pequenos municípios brasileiros: o caso do município de Bom Repouso, MG".

Data da defesa: 10/03/2016

\section{Comissão Julgadora:}

Dra. Maria Edna Tenório Nunes

(Orientadora)

(Pós-Doutoranda/CAPES)

Prof. Associado Valdir Schalch

(Escola de Engenharia de São Carlos/EESC)

Prof. Dr. Bernardo Arantes do Nascimento Teixeira (Universidade Federal de São Carlos/UFSCar)
Resultado:
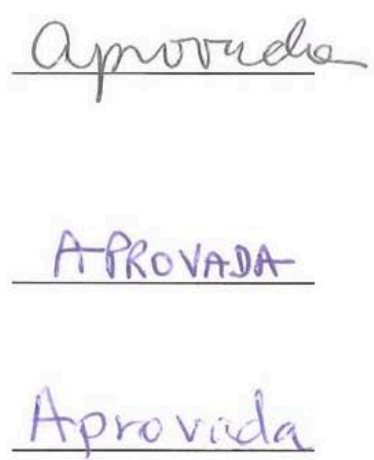

Coordenador do Programa de Pós-Graduação em Ciências da Engenharia Ambiental:

Prof. Associado Frederico Fabio Mauad

Presidente da Comissão de Pós-Graduação:

Prof. Associado Paulo César Lima Segantine 

Dedico este trabalho a Deus, meu guia e amor maior. Aos meus pais e meu irmão, que são as criaturas mais importantes nessa minha passagem. Aos meus amigos maravilhosos, os quais tive a oportunidade de escolher e de ser escolhida. E a todas as notas musicais que me fazem ser quem eu sou. 



\section{AGRADECIMENTOS}

Agradeço primeiramente a Deus, pela força e fé em mim como espírito em constante evolução.

A minha mãe Rosemary, ao meu pai Neymard e ao meu irmão Rafael, pelo apoio, incentivo, preocupação e compreensão.

A minha orientadora Profa. Dra. Maria Edna Tenório Nunes, pela condução e pela condição de amadurecimento dado a mim no desenvolvimento desta pesquisa.

A todos os envolvidos no decorrer dessa pesquisa, pelo apoio, ensinamentos e aprofundamentos dados no desenvolvimento e fechamento da mesma.

Aos professores Evaldo Gaeta Espíndola e Valdir Schalch pelo suporte e incentivo dado a mim desde o início desse novo estudo.

Ao professor Bernardo Teixeira e mais uma vez ao professor Valdir Schalch por todas as contribuições durante e após o processo de defesa.

Aos alunos do Centro de Recursos Hídricos e Ecologia Aplicada da Escola de Engenharia de São Carlos da Universidade de São Paulo, pelas inúmeras conversas e dúvidas debatidas no desenvolvimento e finalização do estudo.

A todos os professores do Programa de Pós-Graduação em Ciências da Engenharia Ambiental da Universidade de São Paulo, aqui representados pelo Coordenador do Programa de Pós Graduação, Prof. Dr. Frederico Mauad, pela dedicação, ensinamentos e pela orientação em dúvidas existentes.

Aos funcionários do Programa de Pós-Graduação em Ciências da Engenharia Ambiental da Escola de Engenharia de São Carlos da Universidade de São Paulo, aqui representados pelos secretários de Pós-Graduação Nelson Emanuel Tessarin e José Luiz Donizete Chiaretto, pelo suporte administrativo e pessoal disponibilizado e sem o qual não seria possível o desenvolvimento do estudo.

Ao CNPq (Conselho Nacional de Desenvolvimento Científico e Tecnológico ), pela concessão de bolsa de mestrado (processo número 130932/2013-2) pelo auxílio financeiro e no desenvolvimento desta pesquisa.

Ao Programa de Pós-Graduação em Ciências da Engenharia Ambiental pela oportunidade disponibilizada para aprimorar os conhecimentos e obtenção do título.

A todos os meus amigos que sempre estiveram em pensamento me apoiando e me dando forças para desenvolver este trabalho. 


\section{RESUMO}

SILVA, M.R. Gestão de embalagens vazias de agrotóxicos - logística reversa em pequenos municípios brasileiros: o caso do município de Bom Repouso, MG. 2016. Dissertação (Mestrado) - Escola de Engenharia de São Carlos, Universidade de São Paulo, São Carlos, 2016.

O Brasil assumiu e mantém desde 2008 o primeiro lugar mundial em consumo de agrotóxicos e, tendo em vista este uso intensivo, é possível estimar a grande quantidade de embalagens vazias de agrotóxicos (EVAs) geradas todos os anos no país. Com a promulgação da Lei 9974 de 2000, a criação do Instituto Nacional de Processamento de Embalagens Vazias (inpEV) em 2001 e a implantação da Política Nacional de Resíduos Sólidos (PNRS) em 2010, a destinação adequada das EVAs por meio da logística reversa passou a ocorrer de maneira mais eficiente, chegando a um percentual de 94\% de devolução em 2014 segundo dados do INPEV. No entanto, este processo foi originalmente concebido para atender grandes áreas rurais, com economias de escala que o favorecem, e portanto não está adequado à realidade de pequenas comunidades rurais, geralmente com infraestrutura precária e mais isoladas. Sendo assim, ainda é comum nos municípios de pequeno porte que essas embalagens sejam queimadas, armazenadas em locais não adequados ou simplesmente abandonadas no campo. Dessa forma, o objetivo deste estudo foi analisar a gestão de EVAs em pequenos municípios agrícolas brasileiros, com foco no processo de logística reversa, a partir de um estudo de caso. Este foi realizado em Bom Repouso, MG, município de 10500 habitantes, caracterizado pela produção de morango e batata, com mão de obra familiar e uso intensivo de agrotóxicos. As seguintes etapas de pesquisa foram desenvolvidas: entrevistas semiestruturadas com os atores da cadeia de logística reversa de EVAs; levantamento documental; análise comparativa entre a quantidade de embalagens vendidas e a quantidade total de embalagens devolvidas entre os anos de 2012-2013 e 2013-2014, bem como um levantamento dos agrotóxicos mais comercializados no município. Verificou-se que, no período 2012-2013, a quantidade de embalagens vendidas foi cerca de 30 vezes maior que a de embalagens devolvidas, e para o período entre 2013-2014 a mesma relação foi da ordem de 26 vezes. Além disso, a massa total de embalagens devolvidas corresponde a apenas 3,3\% da massa de vendidas no período 2012-2013, e 3,8\% para 2013-2014. Ou seja, aproximadamente $96 \%$ das embalagens comercializadas em ambos os períodos não foram devolvidas à central de Pouso Alegre. Além disso, há produtos extremamente tóxicos para a saúde e para o meio ambiente entre os 20 mais vendidos no município. Não estão estabelecidas políticas públicas municipais voltadas à gestão desses resíduos, como pode ser verificado através das entrevistas e do levantamento documental. Dificuldades relacionadas ao armazenamento das EVAs até o momento da devolução e seu transporte até a Central de Recolhimento foram apontadas pelos entrevistados como principais motivos para não cumprir suas responsabilidades e, consequente, descartar inadequadamente esses resíduos.

Palavras-chave: Gestão e Gerenciamento de Resíduos Sólidos. Embalagens Vazias de Agrotóxicos. Logística Reversa. Municípios de Pequeno Porte. 


\section{ABSTRACT}

SILVA, M.R. Empty pesticide containers management - Reverse Logistic in small rural communities: case study of Bom Repouso, MG. 2016. Dissertação (Mestrado) -Escola de Engenharia de São Carlos, Universidade de São Paulo, São Carlos, 2016.

Brazil has taken since 2008 the first place worldwide in pesticide consumption and, in view of this intensive use, it is possible to estimate the large number of empty containers of pesticides (EVAs) generated every year in the country. With the enactment of the 20009974 Law, creating the National Institute of Empty Packaging Processing (inpEV) in 2001 and the implementation of the National Solid Waste Policy (PNRS) in 2010, the proper disposal of EVAs through reverse logistics started to occur in a more organized and effective way, reaching a percentage of $94 \%$ return in 2014. Despite of that, the Brazilian take-back program was originally designed for large rural areas, and may not apply to small rural communities, generally more isolated and with poor infrastructure, that must require large storage and high transport costs. Because of this, it is still very common to burn and bury empty pesticides containers in this areas, store them in inappropriate places or leave them in the fields. Thus, this research aimed to analyze the efficiency of EVAs reverse logistics process in small Brazilian agricultural counties, taking as a case study the municipality of Bom Repouso, MG, Brazil, which is characterized by the production of strawberry and potato on properties with family labor and intensive use of pesticides. Therefore, the research had three steps: interviews were conducted with the chain process participants; a document research was made; as well as a comparative analysis of the amount of packaging sold in the city and the amount returned between the periods of 2012-2014 (considering the requirement of the law that farmers must turn EVAs in a maximum of one year after purchase, there was a comparison between two periods, from the year 2012 to 2013 and 2013 to 2014) and a research on the 20 most traded pesticides in the municipality. It was verified that in the period between 2012-2013, the amount of packaging used was about 30 times higher than the returned packaging, and for the period between 2013-2014 it was about the order of 26 times. Furthermore, the total mass of returned empty containers corresponds to only 3,3\% of the mass sold 2012-2013, and 2013-2014 to $3,8 \%$. In the other words, approximately $96 \%$ of the units sold in both periods were not returned to the center of Pouso Alegre. In addition, there are extremely toxic pesticides both for health and the environment among the top 20 in the county. It is not established municipal public policies for the management of such waste as it could be seen through the interviews and the document research. Proper storage for empty pesticide containers and transportation costs were the main points highlighted by dealers as reasons given by producers for not returning and, consequently, improperly dispose of such waste.

Key-words: Solid Waste Management. Empty Pesticide Containers. Reverse Logistics. Small Rural Communities. 


\section{LISTA DE FIGURAS}

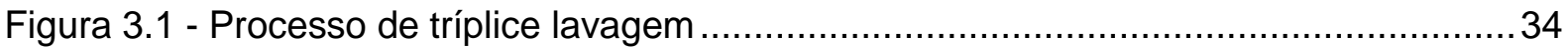

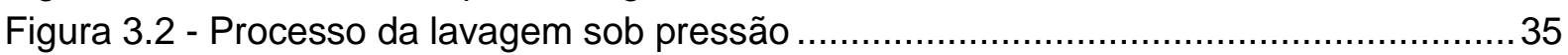

Figura 3.3 - Classificação dos resíduos sólidos quanto a origem ...........................................40

Figura 3.4 - Porcentagem de EVAs destinadas corretamente por país ................................42

Figura 3.5 - Destinação de embalagens vazias de agrotóxicos (EVAs) no Brasil, por região,

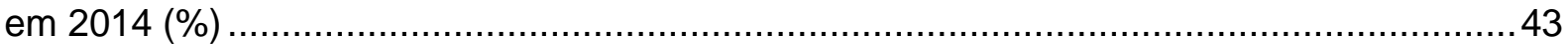

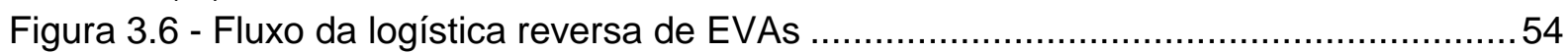

Figura 3.7 - Responsabilidades de cada ator no processo de logística reversa ...................55

Figura 3.8 - Mapa das unidades de recebimento de EVas nas diferentes regiões do país... 56

Figura 4.1 - Localização da bacia hidrográfica de montante do Rio Mogi-Guaçu e do

município de Bom Repouso.

62

Figura 5.1 - Comparativo entre total de embalagens de agrotóxicos vendidas em 2012 e 2013, no município de Bom Repouso, MG, e total de embalagens devolvidas por produtores de municípios à Central de Recolhimento de Pouso Alegre, em 2013 e

2014. .78

Figura 5.2 - Variação das quantidades de EVAs vendidas e devolvidas em função do tempo.

Figura 5.3 - Comparativo entre a massa total de embalagens dos 7 produtos mais comercializados em Bom Repouso, MG, em 2012 e a massa total de EVAs devolvidos à Central de Recolhimento de Pouso Alegre,

2013

Figura 5.4 - Comparativo entre a massa total de embalagens dos 7 produtos mais comercializados em Bom Repouso, MG, em 2012 e a massa total de EVAs devolvidos à Central de Recolhimento de Pouso Alegre, 2014. 


\section{LISTA DE TABELAS}

Tabela 3.1 - Quantidade de embalagens vazias de agrotóxicos (EVAs) devolvidas por ano no Brasil.

Tabela 5.1 - Resultados do processo de equacionamento para obtenção da quantidade total de massa de embalagens vendidas em

2012

76

Tabela 5.2 - Resultados do processo de equacionamento para obtenção da quantidade total de massa de embalagens vendidas em

2013.

Tabela 5.3 - Resultados do processo de equacionamento para obtenção da quantidade total de massa de embalagens devolvidas em 2013 e 2014 


\section{LISTA DE QUADROS}

Quadro 3.1 - Classificação das principais categorias de agrotóxicos quanto ao grupo químico e especificação da ação tóxica

Quadro 3.2 - Classificação toxicológica dos agrotóxicos..............................................28

Quadro 3.3 - Tipos de embalagens de agrotóxicos e suas classificações........................... 32

Quadro 3.4 - Tipos de embalagens de agrotóxicos versus vantagens e desvantagens ........33

Quadro 3.5 - Algumas capacidades das embalagens rígidas....................................... 33

Quadro 4.1 - Etapas, objetivos e métodos da

pesquisa.

Quadro 5.1 - Vinte agrotóxicos mais vendidos em Bom Repouso no ano de 2014 e suas principais características e

funções. 


\section{LISTA DE ABREVIATURAS E SIGLAS}

ABNT - Associação Brasileira de Normas Técnicas

ACRC - Ag Container Recycling Council

adEV - Agendamento de Devolução de Embalagens Vazias

AFIPA - National Association of Manufacturers and Importers of Crop Protection

Products

Andef - Associação Nacional de Defesa Vegetal

BNDES - Banco Nacional de Desenvolvimento Econômico e Social

COEX - Polietileno Co-extrudado Multicamada

CONAMA - Conselho Nacional do Meio Ambiente

COMDEMA - Conselho Municipal de Meio Ambiente

COPAM - Conselho Estadual de Política Ambiental

Cwb - Clima Tropical de Altitude (classificação de Köeppen)

DDT - Diclorodifeniltricloroetano

DL50 - Dose Letal 50\%

EPI - Equipamento de Proteção Individual

ETU - Etilenotiouréia

EVA - Embalagem Vazia de Agrotóxico

FEAM - Fundação Estadual do Meio Ambiente

IA - Ingrediente Ativo

Iarc - International Agency for Research on câncer (Agência Internacional de

Pesquisas do Câncer)

IBAMA - Instituto Brasileiro do Meio Ambiente e Recursos Renováveis

IBGE - Instituto Brasileiro de Geografia e Estatística

IMA - Instituto Mineiro de Agropecuária

INCA - Instituto Nacional de Câncer José Alencar Gomes da Silva

inpEV - Instituto Nacional de Processamento de Embalagens Vazias

kg - Quilograma

L - Litro

MMA - Ministério do Meio Ambiente

NBR - Norma Brasileira Registrada

OMS - Organização Mundial da Saúde 
PEAD - Polietileno de Alta Densidade

PEBD - Polietileno de Baixa Densidade

PET - Polietileno Tereftalato

PMGIRS - Plano Municipal de Gestão Integrada de Resíduos Sólidos

PNDA - Programa Nacional de Defensivos Agrícolas

PNRS - Política Nacional de Resíduos Sólidos

PL - Projeto de Lei

PVA - Polivinil álcool

SCL - Sistema Campo Limpo

SINDAG - Sindicato Nacional da Indústria de Produtos para Defesa Agrícola

SINDIVEG - Sindicato Nacional da Indústria de Produtos para Defesa Vegetal

SisLog - Sistema de Logística

$\mathrm{t}$ - Toneladas

TAC - Termo de Ajustamento de Conduta Ambiental 


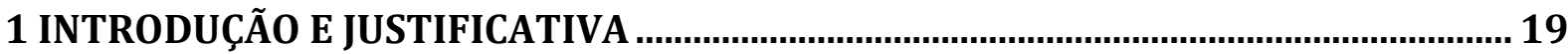

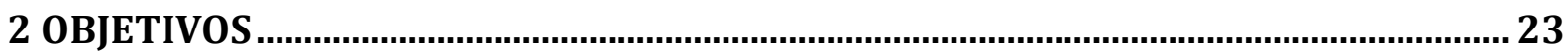

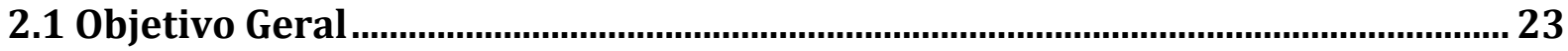

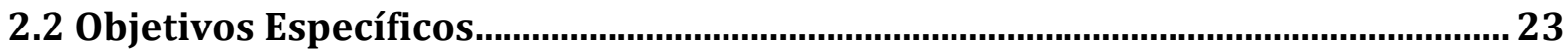

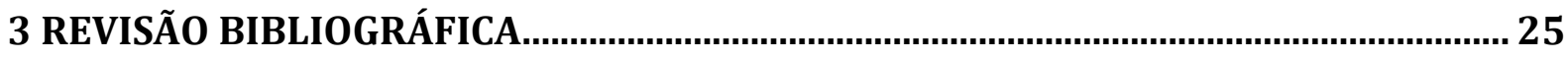

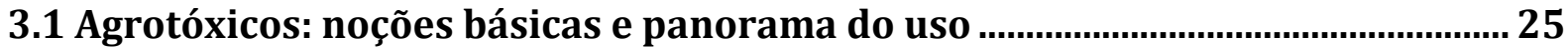

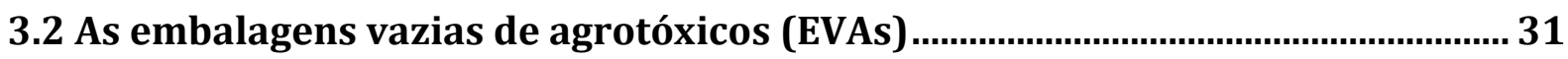

3.3 Considerações básicas sobre Resíduos Sólidos ......................................................... 36

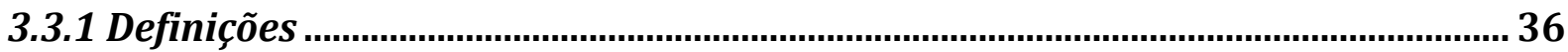

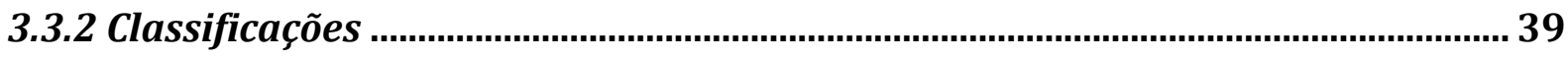

3.4 Panorama da destinação final de EVAs no Brasil e no mundo ............................. 41

3.5 Instrumentos legais relacionados ao uso de agrotóxicos e às EVAs no Brasil.. 43

3.5.1 A política Nacional de Resíduos Sólidos (PNRS) e o Plano Municipal de Gestão

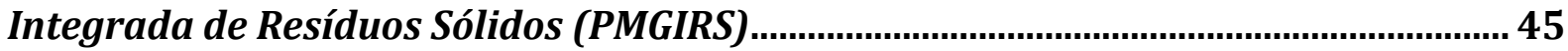

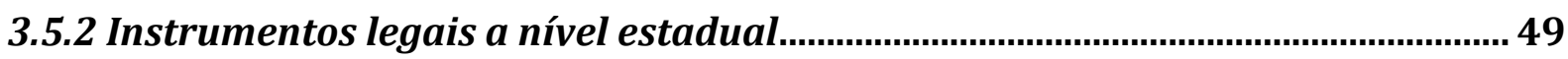

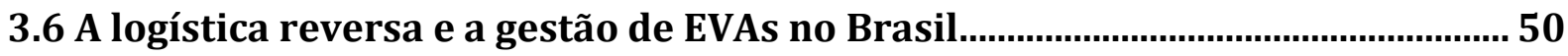

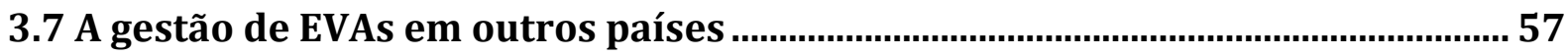

4 METODOLOGIA

4.1 Abordagem metodológica

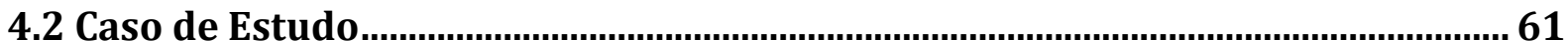

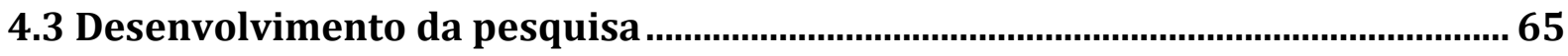

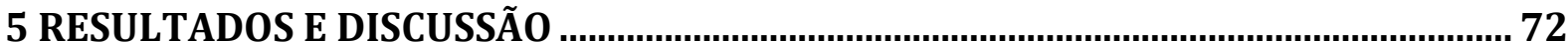

5.1 Análise dos dados de comercialização de agrotóxicos e de recolhimento de

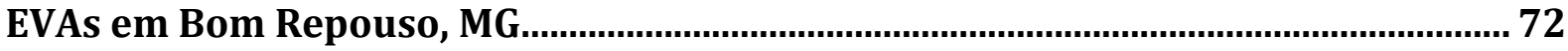

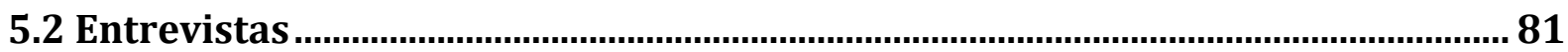

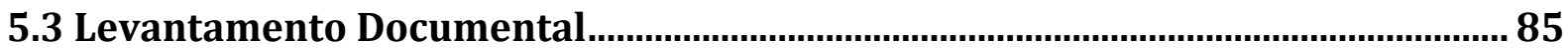

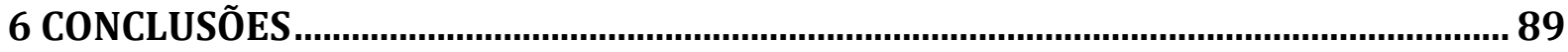

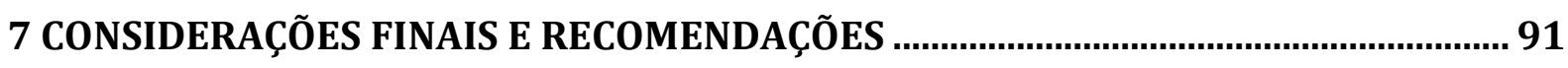

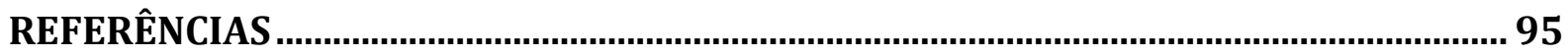





\section{INTRODUÇÃO E JUSTIFICATIVA}

A conservação dos recursos naturais tem sido fortemente prejudicada em razão dos diversos problemas ambientais decorrentes dos efeitos provenientes da produção desenvolvimentista pós - revolução industrial. A geração abundante e diversificada de resíduos sólidos configura-se como um dos mais sérios desses problemas, pois causam impactos negativos não só ao meio ambiente, mas ameaçam diretamente a saúde da própria sociedade.

A questão torna-se ainda mais preocupante porque a gestão e o gerenciamento dos resíduos sólidos não são tarefas fáceis, uma vez que envolvem a articulação entre sociedade, governos e cadeia produtiva (indústrias e comércio). Nem sempre a preocupação interinstitucional é convergente, e no meio rural essas dificuldades são ainda mais visíveis devido à falta de planejamento, execução e recursos, além da ausência de informações a respeito dos resíduos gerados e sua destinação.

O meio rural caracteriza-se ainda pela produção de resíduos específicos denominados agrossilvopastoris, definidos como aqueles gerados nas atividades agropecuárias e silviculturais, incluídos os relacionados a insumos utilizados nessas atividades (BRASIL, 2010). Dentre os resíduos agrossilvopastoris, destacam-se as embalagens vazias de agrotóxicos (EVAs), resultantes do consumo de agrotóxicos.

Essas embalagens podem ser classificadas como resíduos perigosos uma vez que apresentem no mínimo uma das seguintes características: inflamabilidade, corrosividade, reatividade, toxicidade, patogenicidade, carcinogenicidade, teratogenicidade e mutagenicidade, o que está associado a riscos à saúde pública ou à qualidade ambiental, de acordo com lei, regulamento ou norma técnica (BRASIL, 2010). Essa classificação é dada às EVAs que, por não terem sido descontaminadas (por meio de processos de tríplice lavagem ou de lavagem sobpressão), apresentem resíduos do princípio ativo e dos ingredientes inertes da formulação do agrotóxico, que correspondem, em média, a 0,3\% do conteúdo inicial da embalagem (PELISSARI ${ }^{1}, 1999$ apud COMETTI, 2009).

\footnotetext{
1 PELISSARI, A. et al. Tríplice lavagem e destinação das embalagens de defensivos agrícolas: programa terra limpa. Londrina: Seab/Andef, 1999.
} 
Se descartadas sem controle no ambiente, podem levar á contaminação atmosférica, pela evaporação dos resíduos dos agrotóxicos, além de gerar percolados potencialmente tóxicos que, por meio de escoamento superficial ou lixiviação, podem atingir solo, águas superficiais e subterrâneas, contaminando-os (CEMPRE, 2000). Portanto, as EVAs são resíduos com alto potencial poluidor, que podem comprometer os sistemas naturais em diferentes graus e afetar a saúde humana.

Desde a década de 70 o Brasil sempre esteve entre os seis maiores mercados consumidores de agrotóxicos no mundo e, desde 2008, passou a ocupar o primeiro lugar no ranking mundial. Em 2014, alcançou o recorde de 914.220 toneladas de agrotóxicos vendidas (SINDIVEG, 2014). A partir dessas informações, pode-se estimar o alto número de embalagens utilizadas e, por conseguinte, a serem retornadas e destinadas de maneira ambientalmente adequada (CARBONE; SATO; MOORI, 2005).

Com a promulgação da Lei 9974 de 2000, surgiram as primeiras diretrizes legais sobre a destinação adequada de EVAs no Brasil, que pautavam as responsabilidades de cada ator participante do processo de logística reversa dessas embalagens, que posteriormente seria conhecida pela termo "responsabilidade compartilhada". As diretrizes designavam aos consumidores de agrotóxicos a responsabilidade de devolver as EVAs nos estabelecimentos comerciais onde os adquiriram, os quais, por sua vez, teriam de encaminhá-las aos fabricantes para reciclagem ou incineração. Ao Estado ficou designado a fiscalização das devoluções e o licenciamento dos locais de recebimento das EVAs.

Para que esse processo fosse viável, foi criado em 2001 o Instituto Nacional de Processamento de Embalagens Vazias (inpEV), entidade sem fins lucrativos gerida pelas indústrias fabricantes de agrotóxicos e que tem a função de coordenar a logística reversa de EVAs no Brasil. Por meio de um sistema de gestão denominado Sistema Campo Limpo (SCL), o inpEV afirma ter alcançado, desde 2010, um percentual de $94 \%$ de recolhimento de EVAs.

No entanto, algumas falhas neste sistema foram detectadas, principalmente no que tange à situação de pequenas comunidades rurais. Veiga (2009), afirma que a logística reversa coordenada pelo inpEV foi originalmente concebida para atender a grandes áreas rurais, com economias de escala que favorecem o processo, e 
portanto, pode não se adequar à realidade de pequenas comunidades rurais, geralmente com infraestrutura precária e mais isoladas.

Nestas comunidades há um relevante desenvolvimento da agricultura do tipo familiar, desenvolvida por pequenos ou médios produtores. Estes têm papel crucial nas economias municipais, mas por outro lado, são geralmente pouco beneficiados com relação ao acompanhamento técnico para recomendações quanto à adequada utilização de agrotóxicos em suas lavouras e descarte de suas EVAs (SILVA, 2012). A infraestrutura precária desses municípios interfere diretamente no custo de transporte até as centrais e postos de recolhimento e na condição de armazenamento das EVAs nas propriedades dos pequenos agricultores (VEIGA, 2009; VEIGA, 2013), o que favorece ainda mais o descarte inadequado desses resíduos.

Pelo exposto, a presente pesquisa se reveste de importância por expor a realidade dos municípios rurais de pequeno porte e procurar entender como os mesmos têm realizado a gestão das EVAs, considerando principalmente as dificuldades de realizar de forma eficiente a logística reversa desses resíduos. Para tanto, foi realizado um estudo de caso no município de Bom Repouso, localizado na região de montante da bacia hidrográfica do rio Mogi-Guaçu, na porção sul do estado de Minas Gerais.

Trata-se de um município de cerca de 10500 habitantes, onde aproximadamente $50 \%$ de sua população residem na zona rural. O mesmo destacase no cenário regional, estadual e nacional pela produção de batata-inglesa e morango, além de possuir potencial turístico ímpar, principalmente pela beleza de suas cachoeiras e matas. No entanto, caracteriza-se como um município carente de investimentos em saúde e educação e que possui na agricultura familiar a base da renda de sua população (ESPÍNDOLA, 2011).

Apresenta, assim como outros municípios da região, problemas relacionados ao uso intensivo de agrotóxicos e à consequente geração de EVAs que, segundo vários estudos, não recebem destinação ambientalmente adequada (CUNHA, 2009; ESPÍNDOLA, 2011; ESPÍNDOLA; BRIGANTE, 2009; NISHIKAWA, 2012; NUNES, 2010). Estas características de Bom Repouso têm sido relacionadas a problemas ambientais e de saúde pública verificados no município, como casos de intoxicações agudas e crônicas, aumento da incidência de câncer, aumento do número de pessoas com depressão e até mesmo casos de morte decorrentes dessas doenças, 
além da contaminação da fauna e flora do município, o que pode comprometer os ecossistemas como um todo (ESPÍNDOLA; BRIGANTE, 2009; NUNES, 2010; NISHIKAWA, 2012).

Sendo assim, a presente pesquisa se justifica pela necessidade de entender, prevenir e resolver problemas que podem ser gerados a partir da destinação inadequada das EVAs. Para tanto, a mesma pautou-se no levantamento de informações e dados imprescindíveis para uma real compreensão da situação da gestão das EVAS no município, com o intuito de gerar subsídios para um melhor manejo desses resíduos no município.

Visando apresentar os detalhes da pesquisa, esta dissertação foi estruturada em sete capítulos:

- 1: traz a introdução ao tema e justificativa da pesquisa.

- 2: contém os objetivos da pesquisa;

- 3: denominado revisão bibliográfica, contempla o estado da arte referente aos conceitos, classificações e demais informações essenciais para o entendimento da gestão e logística reversa de EVAs.

- 4: descreve a metodologia empregada no levantamento de dados e na pesquisa de campo, bem como os critérios de análise;

- 5: apresenta os resultados do estudo do sistema de gestão e logística reversa de EVAs em Bom Repouso;

- 6: apresenta considerações finais sobre os resultados encontrados na pesquisa e os entraves à logística reversa de EVAs em municípios rurais de pequeno porte, como é o caso de Bom Repouso;

- 7: traz as principais conclusões e recomendações para a gestão e logística reversa de EVAs em Bom Repouso e municípios de mesmo porte e características. 


\section{OBJETIVOS}

\subsection{Objetivo Geral}

O objetivo desta pesquisa foi analisar a eficiência da gestão de embalagens vazias de agrotóxicos em um município agrícola de pequeno porte, com foco no processo de logística reversa, a partir de um estudo de caso no município de Bom Repouso, MG.

\subsection{Objetivos Específicos}

- Obter e analisar informações sobre o consumo de agrotóxicos e a geração de EVAs no município de Bom Repouso, de modo a obter um panorama da realidade de um município de pequeno porte essencialmente agrícola.

- Fazer um diagnóstico do sistema de gestão com foco no processo de logística reversa de EVAs em Bom Repouso, por meio da análise de dados, documentos e entrevistas com atores envolvidos no sistema, visando identificar e compreender possíveis falhas.

- Propor recomendações para melhorias no processo de gestão e gerenciamento das EVAs, de modo que possam se adequar à realidade de Bom Repouso e de outros municípios de pequeno porte essencialmente agrícolas. 


\section{REVISÃO BIBLIOGRÁFICA}

\subsection{Agrotóxicos: noções básicas e panorama do uso}

A busca por maior produtividade agrícola inclui o controle de doenças, pragas e plantas invasoras que acometem as lavouras. Dentre as formas utilizadas para este controle, destaca-se o controle químico, com o uso de agrotóxicos, definidos como quaisquer produtos que têm esta finalidade, incluindo-se pesticidas, fungicidas e herbicidas (CARBONE; SATO; MOORI, 2005).

A Lei $n^{\circ} 7802$, de julho de 1989 , de forma mais abrangente, define os agrotóxicos como

os produtos e os agentes de processos físicos, químicos ou biológicos,
destinados ao uso nos setores de produção, no armazenamento e
beneficiamento de produtos agrícolas, nas pastagens, na proteção de
florestas, nativas ou implantadas, e de outros ecossistemas e também de
ambientes urbanos, hídricos e industriais, cuja finalidade seja alterar a
composição da flora ou da fauna, a fim de preservá-las da ação danosa de
seres vivos considerados nocivos; substâncias e produtos empregados
como desfolhantes, dessecantes, estimuladores e inibidores de crescimento
(BRASIL, 1989, p.1).

Esses produtos também são comumente denominados defensivos agrícolas, mas oficialmente, após grande mobilização da sociedade civil brasileira organizada, o termo agrotóxico ficou definido como o mais correto tecnicamente. Isto porque o mesmo evidencia a toxicidade desses produtos ao meio ambiente e à saúde humana (BOULOMITYS; BRESAOLA JUNIOR, 2013). Como produtos formulados, são obtidos a partir de produtos técnicos ou de pré-misturas. Produtos técnicos, por sua vez, têm nas suas composições teores definidos de ingredientes (ou princípios) ativos e de impurezas, podendo conter ainda estabilizantes e produtos relacionados (SPADOTTO et al., 2004).

Os agrotóxicos podem ser classificados quanto:

a) à sua origem, em:

Orgânicos e Inorgânicos.

b) à especificação de sua ação tóxica (SILVA; FAY, 2004), em:

- Inseticidas: combatem insetos, matando-os por contato e ingestão. 
- Fungicidas: agem sobre os fungos impedindo a germinação, colonização ou erradicando o patógeno dos tecidos das plantas.

- Herbicidas: agem sobre as ervas daninhas, seja em pré - emergência ou pós emergência.

- Acaricidas: eliminam ácaros.

- Nematicidas: eliminam nematóides.

- Moluscicidas: controlam lesmas.

- Raticidas: agem sobre os ratos.

- Bactericidas: controlam bactérias.

c) à formulação (DOMINGUES et al., 2004), em:

- Pó seco: apresenta geralmente cerca de 1 a 10\% dos ingredientes ativo e é aplicado diretamente nas culturas.

- Pó molhável: deve ser diluído previamente em água, formando uma suspensão.

- Pó solúvel: é rara, uma vez que a maioria dos ingredientes ativos não são solúveis em água.

- Granulados: esta formulação é utilizada apenas para inseticidas e alguns herbicidas.

- Concentrado emulsionável: é a formulação líquida mais antiga, sendo composta pelo ingrediente ativo, um solvente e um emulsificante. 
d) ao grupo químico, como apresentado no quadro 3.1 (PERES; MOREIRA; DUBOIS, 2003):

\begin{tabular}{|c|c|c|}
\hline $\begin{array}{c}\text { Classificação quanto à } \\
\text { natureza da praga } \\
\text { controlada }\end{array}$ & $\begin{array}{l}\text { Classificação quanto } \\
\text { ao grupo químico }\end{array}$ & $\begin{array}{c}\text { Exemplos } \\
\text { (produto/substâncias/agentes) }\end{array}$ \\
\hline \multirow{6}{*}{$\begin{array}{l}\text { Inseticidas } \\
\text { (controle de insetos) }\end{array}$} & Inorgânicos & $\begin{array}{l}\text { Fosfato de alumínio, arsenato de } \\
\text { cálcio }\end{array}$ \\
\hline & Extratos vegetais & Óleos vegetais \\
\hline & Organoclorados & Aldrin, ${ }^{*}$ DDT, ${ }^{*}$ BHC $^{*}$ \\
\hline & Organofosforados & $\begin{array}{l}\text { Fenitrotion, Paration, Malation, } \\
\text { Metil-paration }\end{array}$ \\
\hline & Carbamatos & Carbofuran, Aldicarb, Carbaril \\
\hline & $\begin{array}{l}\text { Piretróides sintéticos } \\
\text { Microbiais }\end{array}$ & $\begin{array}{l}\text { Deltametrina, Permetrina } \\
\text { Bacillus thuringiensis }\end{array}$ \\
\hline \multirow{8}{*}{$\begin{array}{l}\text { Fungicidas } \\
\text { (combate aos fungos) }\end{array}$} & Inorgânicos & Calda Bordalesa, enxofre \\
\hline & Ditiocarbamatos & Mancozeb, Tiram, Metiram \\
\hline & Dinitrofenóis & Binapacril \\
\hline & Organomercuriais & Acetato de fenilmercúrio \\
\hline & Antibióticos & Estreptomicina, Ciclo-hexamida \\
\hline & Trifenil estânico & Duter, Brestam \\
\hline & Compostos Formilamina & Triforina, Cloraniformetam \\
\hline & Fentalamidas & Captafol, Captam \\
\hline \multirow{8}{*}{$\begin{array}{l}\text { Herbicidas } \\
\text { (combate às plantas invasoras) }\end{array}$} & Inorgânicos & Arsenito de sódio, cloreto de sódio \\
\hline & Dinitrofenóis & Bromofenoxim, Dinoseb, DNOC \\
\hline & Fenoxiacéticos & CMPP, 2,4-D, 2,4,5-T \\
\hline & Carbamatos & Profam, Cloroprofam, Bendiocarb \\
\hline & Dipiridilos & Diquat, Paraquat, Difenzoquat \\
\hline & Dinitroanilinas & Nitralin, Profluralin \\
\hline & Benzonitrilas & Bromoxinil, Diclobenil \\
\hline & Glifosato & Round-up \\
\hline \multirow{2}{*}{$\begin{array}{l}\text { Desfoliantes } \\
\text { (combate às folhas } \\
\text { indescjadas) }\end{array}$} & Dipiridilos & Diquat, Paraquat \\
\hline & Dinitrofenóis & Dinoseb, DNOC \\
\hline \multirow{3}{*}{$\begin{array}{l}\text { Fumigantes } \\
\text { (combate às bactérias do solo) }\end{array}$} & $\begin{array}{l}\text { Hidrocarbonetos } \\
\text { halogenados }\end{array}$ & Brometo de metila, cloropicrina \\
\hline & $\begin{array}{l}\text { Geradores de Metil- } \\
\text { isocianato }\end{array}$ & Dazomet, Metam \\
\hline & - & Formaldeídos \\
\hline \multirow{2}{*}{$\begin{array}{l}\text { Rodenticidas/Raticidas } \\
\text { (combate aos roedores/ratos) }\end{array}$} & Hidroxicumarinas & Cumatetralil, Difenacum \\
\hline & Indationas & Fenil-metil-pirozolona, pindona \\
\hline \multirow{2}{*}{$\begin{array}{l}\text { Moluscocidas } \\
\text { (combate aos moluscos) }\end{array}$} & Inorgânicos (aquáticos) & Sulfato de cobre \\
\hline & Carbamatos (terrestres) & Aminocarb, Metiocarb, Mexacarbato \\
\hline \multirow[t]{2}{*}{$\begin{array}{l}\text { Nematicidas } \\
\text { (combate aos nematóideos) }\end{array}$} & $\begin{array}{l}\text { Hidrocarbonetos } \\
\text { halogenados }\end{array}$ & Dicloropropeno, DD \\
\hline & Organofosforados & Diclofention, Fensulfotion \\
\hline \multirow{2}{*}{$\begin{array}{l}\text { Acaricidas } \\
\text { (combate aos ácaros) }\end{array}$} & Organoclorados & Dicofol, Tetradifon \\
\hline & Dinitrofenóis & Dinocap, Quinometionato \\
\hline
\end{tabular}

*Proibidos em vários países e no Brasil

Quadro 3.1 - Classificação das principais categorias de agrotóxicos quanto ao grupo químico e especificação da ação tóxica

Fonte: Peres, Moreira e Dubois (2003)

\section{e) à classificação toxicológica:}

A Lei 7.802 de 1989 classifica-os como tóxicos (Classe I), medianamente tóxicos (Classe II), altamente tóxicos (Classe III) e extremamente tóxicos (Classe 
IV). Essa toxicidade é definida com base na dosagem letal (DL50) do agrotóxico. Essa dosagem (Dose Letal 50\%), oral ou dermal, é a quantidade de um tóxico requerida para matar $50 \%$ de uma população de ratos usados nos ensaios toxicológicos e expressa em miligramas por quilogramas de peso vivo (DOMINGUES et al., 2004). A toxicidade do agrotóxico está relacionada aos efeitos à saúde, decorrentes da exposição humana a esses produtos, que pode variar de acordo com o modo de administração. Para tanto, os rótulos dos produtos são identificados por meio de faixas coloridas, conforme o quadro 3.2.

\begin{tabular}{|c|c|c|c|}
\hline Classe Tóxicológica & Toxicidade & DL50 $(\mathbf{m g} / \mathbf{k g})$ & Faixa colorida \\
\hline I & Extremamente tóxico & $\mathbf{5}$ & Vermelha \\
\hline II & Altamente tóxico & Entre 5 e 50 & Amarela \\
\hline II & Medianamente tóxico & Entre 50 e 500 & Azul \\
\hline IV & Pouco tóxico & Entre 500 e 5000 & Verde \\
\hline \multicolumn{4}{r}{} \\
\cline { 2 - 3 } & Quadro 3.2 - Classificação toxicológica dos agrotóxicos \\
& Fonte: Peres, Moreira e Dubois (2003)
\end{tabular}

O uso de produtos para eliminação de pragas e doenças na agricultura ocorre há muito tempo. A primeira geração de agrotóxicos era constituída por compostos inorgânicos à base de flúor, arsênio, mercúrio, selênio, chumbo, bórax, sais de cobre e zinco. Na China, há cerca de 2.000 anos, agricultores já faziam uso de inseticidas de compostos orgânicos à base de piretrina, proveniente de uma planta chamada crisântemo. Esta também era amplamente difundida entre os povos do deserto, que protegiam seus armazéns de grãos com pó de piretro (BULL; HATHAWAY ${ }^{2}$ apud MALINOWSKI; MALINOWSKI, 2011).

No século $X X$, foi consolidado o marco inicial da era "química" na produção vegetal, com a introdução da molécula sintética do herbicida DDT (diclorodifeniltricloroetano) por Muller em 1931, o que proporcionou o reconhecimento da eficiência do controle químico na proteção das lavouras (NUNES; RIBEIRO, 1999). Mas foi a partir da chamada Revolução Verde que os agrotóxicos passaram a ser difundidos e utilizados em larga escala.

\footnotetext{
2 BULL, D.; HATHAWAY, D. Pragas e venenos: agrotóxicos no Brasil e no mundo. Petrópolis: Vozes, 1986.
} 
Segundo Brum (1988), a Revolução Verde foi um programa que tinha como objetivo explícito contribuir para o aumento da produção e produtividade agrícola no mundo. Isso se daria a partir do desenvolvimento de experiências no campo da genética vegetal, com foco na criação e multiplicação de sementes adequadas às condições dos diferentes solos e climas e resistentes às doenças e pragas, bem como da descoberta e aplicação de técnicas agrícolas ou tratos culturais mais modernos e eficientes (BRUM, 1988).

Iniciada nos Estados Unidos em meados dos anos 1940, a Revolução Verde teve seu impulso no pós-guerra. Em sua segunda fase, a partir dos anos 60, tinha como intuito uma "rearticulação da estratégia da produção de alimentos no mundo". No Brasil, atingiu o auge na década 1970, com a criação do Programa Nacional de Defensivos Agrícolas (PNDA). Este condicionava a concessão do crédito rural à utilização de parte desse recurso para a compra de agrotóxicos. Essa foi a estratégia para que o Estado conseguisse implementar o pacote tecnológico que representava a "modernidade" na agricultura (SIQUEIRA et al., 2013). Isso levou o Brasil a figurar sempre entre os mais importantes mercados consumidores para a indústria dos agrotóxicos,

Entre 1964 e 1991, houve um aumento no emprego desses produtos no país, da ordem de 276,2\% (CAMPANHOLA; BETTIOL, 2003; PERES; MOREIRA; DUBOIS, 2003). Em 2008, segundo dados do Sindicato Nacional de Indústrias de Produtos para Defesa Agrícola (SINDAG), o país alcançou o posto de maior consumidor mundial de agrotóxicos e, em 2010, o mercado nacional movimentou cerca de US\$ 7,3 bilhões e representou $\square 19 \%$ do mercado global de agrotóxicos. Já em 2011 o crescimento se manteve, com um aumento de 16,3\% das vendas, alcançando US\$ 8,5 bilhões, sendo que as lavouras de soja, milho, algodão e canade-açúcar representam 80\% do total das vendas do setor (SINDAG, 2012). Já os Estados Unidos foram responsáveis por $17 \%$ do mercado mundial, que girou em torno de US\$ 51,2 bilhões (ANVISA; UFPR, 2012).

Em 2014 o Brasil obteve seu recorde de consumo, chegando a 914.220 toneladas de agrotóxicos vendidas (SINDIVEG, 2014). O faturamento totalizou US $\$ 12,249$ bilhões em 2014, contra US\$11,454 bilhões em 2013, representando aumento de 6,9\% em 12 meses (IEA, 2015).

Com relação à intensidade do uso de agrotóxicos no país, o Censo Agropecuário Brasileiro (IBGE, 2010) indica que 27\% das pequenas propriedades 
rurais (de 0 a 10 hectares), 36\% das propriedades de 10 a 100 hectares e $80 \%$ das propriedades maiores de 100 hectares usam agrotóxicos (BOMBARDI, 2011).

Dessa forma, fica comprovada a importância desses insumos para a agricultura brasileira, que é uma das principais atividades econômicas do país. A mesma, juntamente com a pecuária, foi em 2014 responsável por 22\% a 23\% do PIB total da economia brasileira, com cerca de $\mathrm{R} \$ 1,1$ trilhão. Desse total, as atividades agrícolas representam 70\% do valor produzido no ano (BRASIL, 2014).

Por outro lado, este uso intensivo de agrotóxicos contribui para aumento dos riscos à saúde humana e ambiental, uma vez que seu uso nem sempre é acompanhado de prescrições técnicas adequadas, incluindo o receituário agronômico (SIQUEIRA et al., 2013).

No que diz respeito à saúde humana, o Instituto Nacional de Câncer José Alencar Gomes da Silva (INCA), órgão do Ministério da Saúde, afirma que o uso intensivo e irresponsável de agrotóxicos é muito grave, pois a presença de resíduos dos mesmos não ocorre apenas em alimentos in natura, mas também em muitos produtos alimentícios processados pela indústria, como biscoitos, salgadinhos, pães, cereais matinais, lasanhas, pizzas e outros que têm como ingredientes o trigo, o milho e a soja, por exemplo. Além disso, devido ao processo de bioacumulação, podem ser encontrados em carnes e leites de animais que se alimentam de ração com traços de agrotóxicos (INCA, 2015).

Portanto, as intoxicações humanas por agrotóxicos podem decorrer da exposição direta durante as aplicações às culturas, bem como por meio de consumo de alimentos ou água contaminados com seus resíduos. Os perigos relacionados à exposição, contato direto, inalação ou ingestão dos agrotóxicos varia conforme sua toxicidade, grau de contaminação e tempo de exposição (CASTRO; CONFALONIERI, 2005). Os efeitos decorrentes podem ser agudos ou crônicos, como dificuldade respiratória, lesões renais e hepáticas, Mal de Parkinson, cânceres, infertilidade, impotência, abortos, malformações, neurotoxicidade, desregulação hormonal, efeitos sobre o sistema imunológico e câncer, entre outras mais (INCA, 2015; PERES; MOREIRA, 2007).

Em relação aos prejuízos ambientais decorrentes da poluição por agrotóxicos, também há grande preocupação, com destaque para a distribuição generalizada de resquíscios dos mesmos em todo o mundo: 
"A presença de agrotóxicos tem sido registrada em águas superficiais,
subterrâneas e pluviais (FUNARI et al., 1995; BUSER, 1990).
Concentrações de resíduos desses produtos foram identificadas no orvalho
(GLOTFELTY et al., 1987), na neve do ártico (GREGOR e GUMMER, 1989)
e na névoa dos oceanos (SCHOMBURG e GLOTFELTY, 1991). Os
agrotóxicos também foram encontrados na atmosfera, mesmo distante de
áreas agrícolas (GROVER et al., 1997; LAABS et al., 2002)" (COMETTI,
2009).

As características dos agrotóxicos que mais prejudicam a saúde humana e o meio ambiente são a sua toxicidade, sua persistência no ambiente e a sua mobilidade, uma vez que os mesmos podem se deslocar no solo, na água e no ar. O fato de se acumular no solo e na biota permite que seus resíduos estejam vulneráveis para alcançar os sistemas superficiais por deflúvio superficial (runoff) e os sistemas subterrâneos, por lixiviação. Também podem afetar o ar, por meio da evaporação de resíduos das superfícies das culturas ou dos solos contaminados. Além disso, o uso indiscriminado de agrotóxicos também pode levar à seleção de pragas resistentes e eliminar certos microrganismos indispensáveis para a cadeia alimentar (LANDON; JACOBSEN; JOHNSON, 1990).

A contaminação de mananciais hídricos, superficiais ou subterrâneos, apresenta-se como a principal fonte de risco proveniente da utilização de agrotóxicos, sendo que os efeitos dessa contaminação podem ser observados a quilômetros de distância das áreas-fonte. Portanto, se uma região agrícola, com uso intensivo de agrotóxicos, estiver localizada próxima a um manancial hídrico que abasteça uma cidade, a qualidade da água consumida estará seriamente sob o risco de uma contaminação, embora a mesma esteja localizada bem distante da região agrícola. Assim, não só a população residente próxima à área agrícola estaria exposta aos agrotóxicos, mas também toda a população do núcleo urbano.

\subsection{As embalagens vazias de agrotóxicos (EVAs)}

A partir do consumo de agrotóxicos tem-se como consequência a geração de embalagens vazias dos mesmos. Como pôde ser visto, esta é bastante considerável no Brasil.

O decreto 4074/2002 define embalagem como invólucro, recipiente ou qualquer forma de acondicionamento, removível ou não, destinado a conter, cobrir, empacotar, envasar, proteger ou manter os agrotóxicos, seus componentes e afins (BRASIL, 2002). Estes se apresentam no mercado de diferentes formas (líquida, 
granulada, pó, pó molhável, gás, pasta, pastilha, tablete, cartucho, gel, bastão, etc) e devido a isso, há vários tipos de embalagens, feitas para armazenar da melhor maneira cada uma das formas apresentadas (COMETTI, 2009).

De modo geral, existem dois tipos de embalagens de agrotóxicos: laváveis e não-laváveis. Estas podem ser classificadas em rígidas ou flexíveis, e primárias ou secundárias, como apresentado no Quadro 3.3. As embalagens rígidas podem ser de vidro, plástico (Polietileno de alta densidade - PEAD, polietileno co-extrudado multicamada - COEX ou polietileno tereftalato - PET), metal (aço, folha de flandres ou alumínio) e fibrolata, e podem conter líquidos (miscíveis ou não em água), aerossóis autopropelentes, gases liquefeitos e granulados. Das embalagens rígidas, apenas as embalagens de aerossóis não podem ser lavadas (COMETTI, 2009).

Já as embalagens flexíveis podem ser de papelão; papel multifolhado; cartolina (celulose); plástico (polietileno de baixa densidade - PEBD) ou mistas (papel e plástico metalizado; papel e alumínio plastificado ou papel plastificado), e não podem ser lavadas. As formas mais comuns de encontrarmos essas embalagens no Brasil são no formato de sacos plásticos, cartuchos de cartolina, sacos de papel ou caixas coletivas de papelão.

\begin{tabular}{|c|c|c|c|}
\hline \multicolumn{2}{|c|}{ TIPOS DE EMBALAGENS } & \multicolumn{2}{c|}{ CLASSIFICAÇÕES } \\
\hline \multirow{2}{*}{$\begin{array}{c}\text { Embalagens não- } \\
\text { laváveis }\end{array}$} & \multicolumn{1}{|c|}{ Aerossóis } & Não-flexíveis & Primárias \\
\cline { 2 - 4 } & $\begin{array}{l}\text { Papelão; papel multifolhado; cartolina, alguns tipos de } \\
\text { plástico ou mistas }\end{array}$ & Flexíveis & $\begin{array}{c}\text { Primárias ou } \\
\text { secundárias }\end{array}$ \\
\hline Embalagens laváveis & Vidro, metal e plástico & Não-flexíveis & $\begin{array}{l}\text { Primárias ou } \\
\text { secundárias }\end{array}$ \\
\hline
\end{tabular}

Quadro 3.3 - Tipos de embalagens de agrotóxicos e suas classificações

Fonte: Modificado de Cometti (2009)

Cometti (2009) destaca ainda a existência de embalagens retornáveis e embalagens hidrossolúveis. Estas possuem como matéria prima polímeros hidrossolúveis, sendo o polivinil álcool (PVA) o mais comumente utilizado. Já as embalagens retornáveis são reabastecíveis e reutilizáveis, podendo ter diferentes tamanhos, geralmente acima de 200 litros. São confeccionadas em aço inoxidável ou plástico de alta resistência. As vantagens e desvantagens de cada tipo de embalagem são presentadas no Quadro 3.4. 


\begin{tabular}{|c|c|c|}
\hline $\begin{array}{c}\text { Tipo de } \\
\text { Embalagem }\end{array}$ & Vantagens & Desvantagens \\
\hline METÁLICAS & $\begin{array}{l}\text { leves/menor volume; } \\
\text { resistentes a impactos (em } \\
\text { parte); } \\
\text { impressão litográfica boa; } \\
\text { não absorvem umidade; } \\
\text { impermeáveis a trocas gasosas; } \\
\text { e, } \\
\text { recicláveis }\end{array}$ & $\begin{array}{l}\text { reativas (necessitam de } \\
\text { revestimento); } \\
\text { opacas e oxidáveis; } \\
\text { revestimento interno frágil a } \\
\text { impactos e falhas na costura; } \\
\text { adsorventes (o revestimento); } \\
\text { fechamento precário; } \\
\text { produzem centelha; } \\
\text { sujeitas a envelhecimento, a } \\
\text { perfuração e a vazamento. }\end{array}$ \\
\hline $\begin{array}{l}\text { PLÁSTICAS } \\
\text { RÍGIDAS }\end{array}$ & $\begin{array}{l}\text { leves/menor volume; } \\
\text { não oxidáveis; } \\
\text { não produzem centelha; e, } \\
\text { resistentes a impactos. }\end{array}$ & $\begin{array}{l}\text { opacas (com exceção do PET); } \\
\text { reativas a certas formulações; } \\
\text { adsorventes e absorvem umidade; } \\
\text { muito atrativas; e, } \\
\text { permeáveis a trocas gasosas } \\
\text { (exceto COEX) e reciclagem } \\
\text { problemática. }\end{array}$ \\
\hline VIDRO & $\begin{array}{l}\text { transparentes; } \\
\text { não reativas e não oxidáveis; } \\
\text { impermeáveis a trocas gasosas; } \\
\text { não adsorventes; } \\
\text { não absorvem umidade; } \\
\text { fechamento; } \\
\text { boa impressão em "silk-screen"; } \\
\text { resistentes ao envelhecimento; } \\
\text { não produzem centelhas; e, } \\
\text { recicláveis. } \\
\end{array}$ & $\begin{array}{l}\text { frágeis (necessitam de } \\
\text { acondicionamento extra); } \\
\text { pesadas (oneram o custo do } \\
\text { transporte); } \\
\text { volumosas; e, } \\
\text { limitação de capacidade. }\end{array}$ \\
\hline HIDROSSOLÚVEIS & $\begin{array}{l}\text { melhor aproveitamento do ativo; } \\
\text { diminui contato direto com o } \\
\text { ativo; } \\
\text { leves/menor volume; } \\
\text { não oxidáveis; } \\
\text { não reativas. }\end{array}$ & $\begin{array}{l}\text { não podem acondicionar produto } \\
\text { na forma líquida; } \\
\text { dissolvem na presença de } \\
\text { umidade; } \\
\text { exigem maior segurança no } \\
\text { transporte e armazenamento. }\end{array}$ \\
\hline
\end{tabular}

Quadro 3.4 - Tipos de embalagens de agrotóxicos versus vantagens e desvantagens Fonte: Adaptado de AESASP ${ }^{3}$ (1992 apud COMETT (2009)

A capacidade das embalagens é outra característica que varia muito. As flexíveis plásticas normalmente se apresentam como sacos de 0,5 a $30 \mathrm{~kg}$, enquanto que as flexíveis celulósicas, como caixas coletivas de 1 a 50 unidades (embalagens de papelão) e cartuchos de 0,5 a $2 \mathrm{~kg}$ (embalagens de cartolina). Há ainda os sacos de papel, com 1 a $30 \mathrm{~kg}$ de produto. As embalagens rígidas também apresentam capacidades variadas, como mostra o Quadro 3.5.

\begin{tabular}{|c|c|c|}
\hline \multicolumn{2}{|c|}{ Tipo de Embalagem } & Capacidade \\
\hline \multirow{2}{*}{ Metálicas } & Tambores & $50,100,200$ litros \\
\cline { 2 - 3 } & Baldes & 10,20 litros e 25 kg \\
\cline { 2 - 3 } & Latas & $1,1 / 2$ e 2 litros \\
\hline \multirow{2}{*}{ Plásticas* $^{*}$} & Bombonas & 10 e 20 litros \\
\cline { 2 - 3 } & Botijas & 5 litros \\
\cline { 2 - 3 } & Garrafas & 1 litro \\
\hline Vidros & Garrafas & $1 / 4,1 / 2$ e 1 litro \\
\hline Fibrolatas & Embalagens & 5 e $20 \mathrm{~kg}$ \\
\hline
\end{tabular}

Quadro 3.5 - Algumas capacidades das embalagens rígidas Fonte: Cometti (2009)

\footnotetext{
${ }^{3}$ AESASP. Associação de Engenheiros Agrônomos do Estado de São Paulo (AEASP). Manual de destinação final de embalagens vazias de produtos fitossanitários. São Paulo, 1998.
} 
As características de periculosidade são conferidas às EVAs porque, após a sua utilização, a embalagem geralmente contém resíduos do produto ativo, que correspondem, em média, a 0,3\% do volume inicial da embalagem (PELISSARI ${ }^{4}$, 1999 apud COMETTI, 2009). Dessa maneira, as embalagens podem causar contaminações assim como os agrotóxicos, uma vez que, se descartadas sem controle no ambiente, podem produzir percolados potencialmente tóxicos e migrar para águas superficiais e subterrâneas, contaminando o solo e lençóis freáticos (CEMPRE, 2000).

Já as embalagens vazias de agrotóxicos lavadas corretamente através dos processos de "tríplice lavagem" ou "lavagem sob pressão" são classificadas como resíduos sólidos não perigosos e podem ser recicladas normalmente.

A tríplice lavagem e a lavagem sob pressão são processos que visam a descontaminação das embalagens vazias. Na tríplice lavagem são realizados três enxágues, como ilustrado pela Figura 3.1.

\section{TRÍPLIGE LAUAGEM}
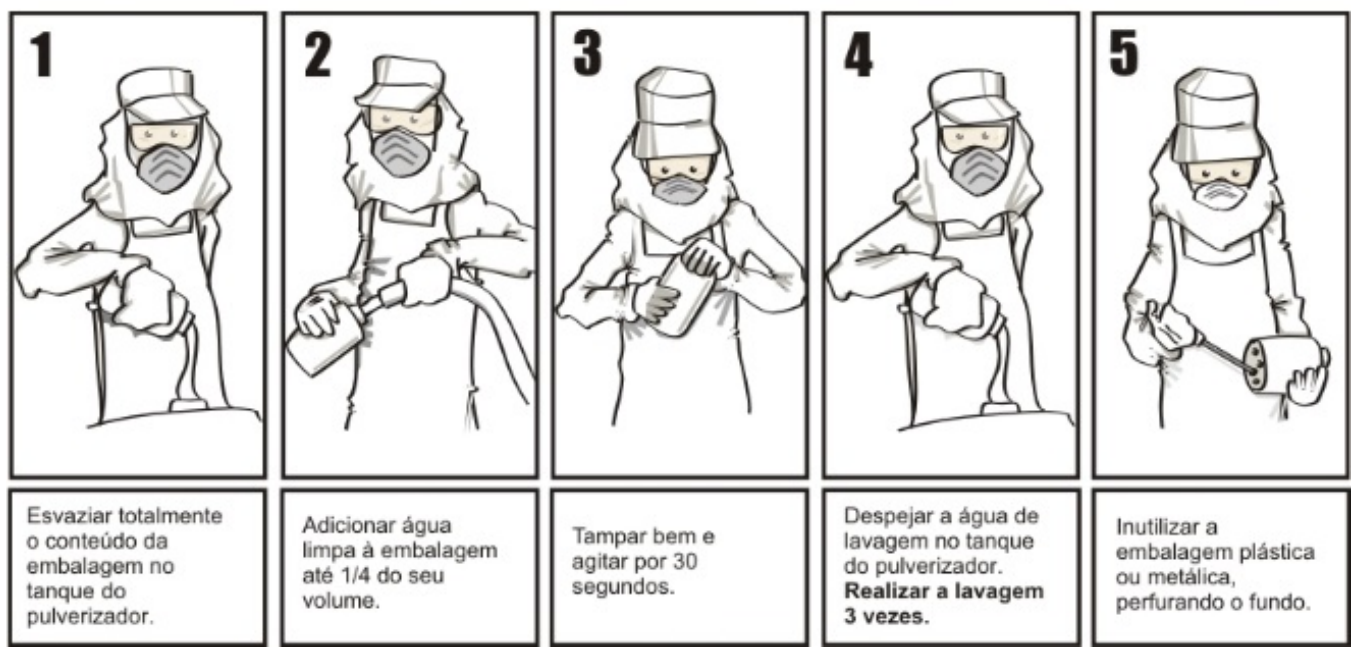

Figura 3.1 - Processo de tríplice lavagem Fonte: Cheminova (2012)

Neste processo coloca-se a água até um quarto do volume da embalagem; fecha-se bem a tampa e agita-se vigorosamente o recipiente em todos os sentidos, durante aproximadamente 30 segundos, de forma a remover os resíduos do produto que estiverem aderidos às superfícies internas; a água de enxágue deve ser

4 PELISSARI, A. et al. Tríplice lavagem e destinação das embalagens de defensivos agrícolas: programa terra limpa. Londrina: Seab/Andef, 1999. 
transferida para o tanque do equipamento de aplicação (para ser reutilizada nas áreas recém-tratadas), tomando-se o cuidado para não espirrar; manter a embalagem sobre a abertura do tanque do equipamento por aproximadamente 30 segundos depois de esvaziado; repetir estes procedimentos mais duas vezes.

Já a lavagem sob pressão caracteriza-se como um sistema de lavagem integrado ao pulverizador, em que a bomba deste equipamento é usada para gerar a pressão para o bico de lavagem (Figura 3.2). A água limpa utilizada para lavagem das embalagens é captada pela própria bomba do pulverizador de um tanque extra que pode ou não estar integrado ao equipamento. O gatilho deve ser acionado para liberação da água do equipamento por 30 segundos, movimentando a ponta, de modo que o jato atinja todas as partes da superfície interna da embalagem (COMETTI, 2009).

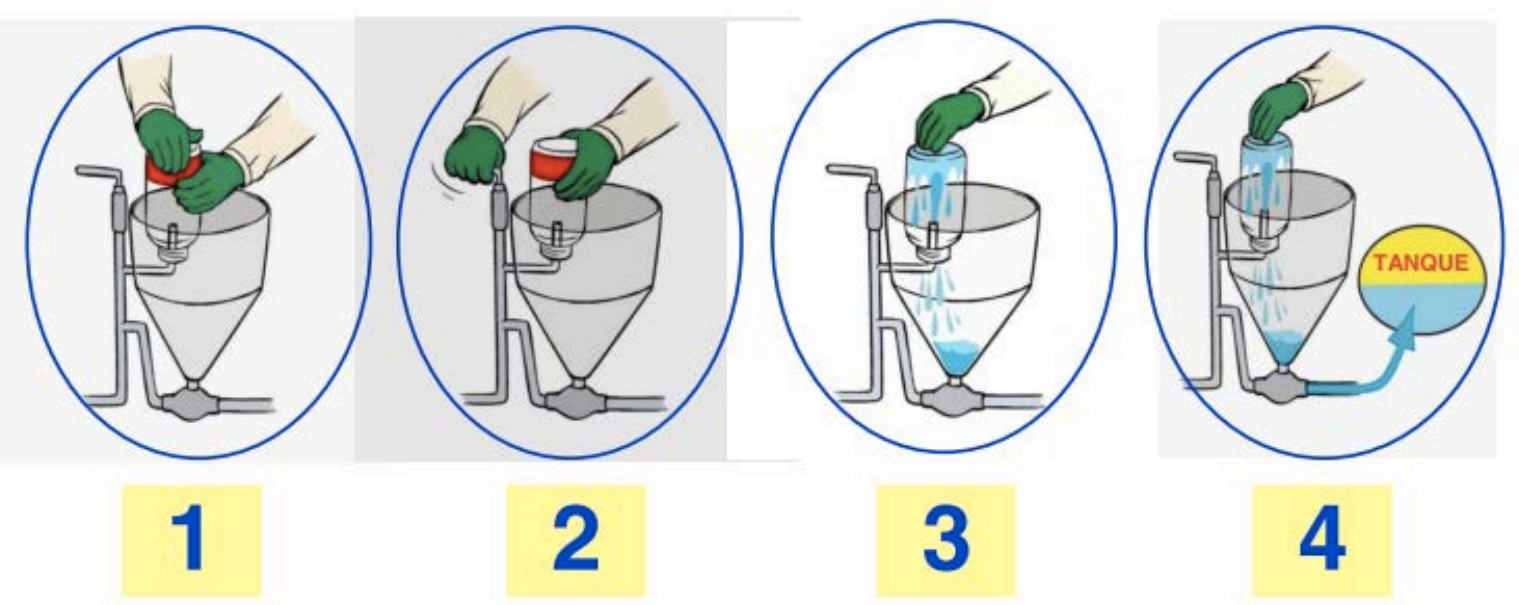

Figura 3.2 - Processo da lavagem sob pressão Fonte: Machado Neto (2015)

Como definido na Lei no 7.802/1989 (BRASIL, 1989), as embalagens devem ser projetadas visando operações que auxiliem a eliminação da maior parte dos resíduos, e que facilitem o armazenamento e o transporte. Desde a implementação desta lei, o perfil das embalagens se alterou completamente, passando de $25,2 \%$ de embalagens plásticas, na safra 1987-1988, para 88,5\%, na safra 1995-1996 (IPEA, 2013).

Entendendo as EVAs como resíduos sólidos complexos, por sua diversidade de formas e capacidades, bem como pelo seu conteúdo que a leva a ser caraterizada como resíduo perigoso, faz-se necessária a revisão sobre alguns conceitos básicos sobre os resíduos sólidos de maneira geral. Os mesmos são apontados a seguir. 


\title{
3.3 Considerações básicas sobre Resíduos Sólidos
}

\subsubsection{Definições}

As intervenções humanas sobre os recursos naturais, sejam de qualquer natureza, sempre resultam na geração de resíduos. O grande problema é a excessiva produção dos mesmos que, por sua qualidade e quantidade, constituem a causa de graves problemas ambientais e sociais.

Essa realidade é consequência dos hábitos de consumo proporcionados pelo desenvolvimento baseado no fator econômico. Sendo assim, a destinação final adequada para estes resíduos tornou-se um dos maiores desafios a serem enfrentados pela sociedade, administradores públicos e pesquisadores (ANDRADE, 2011; CÓRDOBA, 2010; PAULO, 2013; TROTTA, 2011).

A definição oficial do termo "resíduos sólidos" passou a vigorar no Brasil em 2010, após a promulgação da Política Nacional de Resíduos Sólidos (PNRS), instituída pela Lei 12.305/2010 e regulamentada pelo Decreto 7.404/2010 (CÓRDOBA, 2014). Assim, resíduos sólidos são definidos como:

\begin{abstract}
material, substância, objeto ou bem descartado resultante de atividades humanas em sociedade, a cuja destinação final se procede, se propõe proceder ou se está obrigado a proceder, nos estados sólido ou semissólido, bem como gases contidos em recipientes e líquidos cujas particularidades tornem inviável o seu lançamento na rede pública de esgotos ou em corpos d'água, ou exijam para isso soluções técnica ou economicamente inviáveis em face da melhor tecnologia disponível (BRASIL, 2010, p.1).
\end{abstract}

A adoção desta definição é muito importante. Antes da PNRS, diversos autores conceituavam diferentemente os resíduos sólidos, o que muitas vezes gerava dúvidas ou divergências de interpretação. Após a lei ser sancionada, vários profissionais passaram a adotar as definições oficiais, facilitando a comunicação nos sistemas de gestão de empresas, planos de gestão de resíduos de municípios e textos científicos (CÓRDOBA, 2014).

Outra definição muito utilizada é a da NBR 10004, elaborada pela Associação Brasileira de Normas Técnicas (ABNT) em 2004. Ela designa os resíduos sólidos como

aqueles nos estados sólidos e semi-sólidos, que resultam de atividades da comunidade de origem: industrial, doméstica, hospitalar, comercial, agrícola, de serviços e de varrição. Ficam incluídos, nesta definição os lodos provenientes de sistemas de tratamento de água, aqueles gerados em equipamentos e instalações de controle de poluição, bem como 
determinados líquidos, cujas particularidades tornem inviável seu lançamento na rede pública de esgoto ou corpos de água, ou exijam para isso soluções técnica e economicamente inviável em face à melhor técnica disponível (ABNT, 2004, p.1).

Esta definição foi a mais utilizada pelos profissionais da área até o surgimento do novo conceito apresentado na PNRS. Quando comparadas, observamos que a principal diferença relaciona-se à inclusão de substâncias não-sólidas como resíduos sólidos. No conceito da política, incluem-se os gases contidos em recipientes (frascos de aerossóis como embalagens de desodorantes ou inseticidas, gases contidos em aparelhos de ar-condicionado, freezers e geladeiras). Já na definição da NBR 10004, incluem-se os resíduos no estado semissólidos (lodos provenientes de sistemas de tratamento de água, e aqueles gerados em equipamentos e instalação de controle de poluição).

Para Souto e Povinelli (2013), a necessidade de incluir na definição os diferentes estados físicos poderia facilitar a gestão e gerenciamento desses resíduos, considerando principalmente a viabilidade de sua disposição final adequada. Os lodos, apesar de semissólidos, se considerados como resíduos sólidos, poderiam ser co-dispostos em aterros licenciados para tal finalidade, assim como os resíduos líquidos perigosos, que seriam passíveis de armazenamento em tambores para disposição final em aterros industriais. Já os gases contidos em recipientes, caso não fossem considerados como resíduos sólidos, deveriam ser retirados dos recipientes, o que seria inviável do ponto de vista econômico e ecológico (SOUTO; POVINELLI ${ }^{5}, 2013$ apud CÓRDOBA, 2014).

Outro conceito importante delineado na PNRS foi o de "rejeitos", considerados resíduos sólidos que, depois de esgotadas todas as possibilidades de tratamento e recuperação por processos tecnológicos disponíveis e economicamente viáveis, não apresentem outra possibilidade que não a disposição final ambientalmente adequada (BRASIL, 2010).

Segundo Schalch, Castro e Córdoba (2014), esse conceito é importante, pois considera a evolução tecnológica e o desenvolvimento de novos processos. Sendo assim, certos resíduos atualmente considerados inservíveis - ou seja, rejeitos poderiam, em um dado momento, ser aproveitados de algum modo e não terem

\footnotetext{
5 SOUTO, G.D.B; POVINELLI, J. Resíduos sólidos. In: CALIJURI, M.C.; CUNHA, D.G.F. (Coord.).
} Engenharia ambiental. Rio de Janeiro, Elsevier, 2013. Cap.22, p.565-588. 
como destino a disposição em aterro, indicada apenas para as frações não mais passíveis de valorização (FRICKE et al., 2015).

Outro ponto importante para a área de resíduos sólidos é a diferença entre os termos gestão e gerenciamento. Estas palavras não têm o mesmo significado, mas muitas vezes são utilizadas como sinônimos, tanto na língua portuguesa quanto na inglesa que, inclusive, usa o termo management para se referir a ambas (SCHALCH; CASTRO; CÓRDOBA, 2014).

Leite $^{6}$ (1997 apud SCHALCH; CASTRO; CÓRDOBA, 2014), define gestão como um conjunto de normas e diretrizes que regulamentem os arranjos institucionais, a partir da identificação dos diferentes agentes envolvidos e seus respectivos papéis, os instrumentos legais e os mecanismos de financiamento.

Há também a definição do termo "gestão integrada de resíduos sólidos", estabelecida no capítulo II da PNRS como o conjunto de ações voltadas para a busca de soluções para os resíduos sólidos, de forma a considerar as dimensões política, econômica, ambiental, cultural e social, com controle social e sob a premissa do desenvolvimento sustentável (BRASIL, 2010).

Desta forma, observa-se que o termo gestão abrange as atividades referentes à tomada de decisões estratégicas e à organização do setor para esse fim, envolvendo instituições, políticas, instrumentos e meios (SCHALCH et al., 2002).

Já o termo gerenciamento está atrelado à parte prática da gestão, ou seja, é a realização do que a gestão delibera, por meio da ação administrativa, de controle e planejamento de todas as etapas do processo. É definido na PNRS como o "conjunto de ações exercidas, direta ou indiretamente, nas etapas de coleta, transporte, transbordo, tratamento e destinação final ambientalmente adequada dos resíduos sólidos e disposição final ambientalmente adequada dos rejeitos".

Assim, Schalch et al. (2002) resume: gestão é o conjunto de propostas, princípios, normas e funções que visam estabelecer o controle de produtividade e manejo dos resíduos sólidos, e o gerenciamento seria o conjunto de ações efetivamente empregadas para atingir os objetivos propostos na gestão.

Para tanto e visando a construção de um modelo de gestão de resíduos sólidos são indispensáveis:

\footnotetext{
${ }^{6}$ LEITE, W.C.A. Estudo da gestão de resíduos sólidos: uma proposta de modelo tomando a unidade de gerenciamento de recursos hídricos (UGRHI-5) como referência. 1997. 270p. Tese (Doutorado) - Escola de Engenharia de São Carlos, Universidade de São Paulo, São Carlos, 1997.
} 
- reconhecimento dos diversos agentes sociais envolvidos, identificando os papéis por eles desempenhados e promovendo a sua articulação;

- consolidação da base legal necessária e dos mecanismos que viabilizem a implementação das leis;

- mecanismos de financiamento para a auto-sustentabilidade das estruturas de gestão e do gerenciamento;

- informação à sociedade, empreendida tanto pelo poder público quanto pelos setores produtivos envolvidos, para que haja um controle social;

- $\quad$ sistema de planejamento integrado, orientando a implementação das políticas públicas para o setor (SCHALCH et al., 2002).

\subsubsection{Classificações}

A PNRS classifica os resíduos quanto à sua origem e quanto à sua periculosidade. Quanto à origem, são divididos em:

a) resíduos domiciliares: os originários de atividades domésticas em residências urbanas;

b) resíduos de limpeza urbana: os originários da varrição, limpeza de logradouros e vias públicas e outros serviços de limpeza urbana;

c) resíduos sólidos urbanos: os englobados nas alíneas a e b;

d) resíduos de estabelecimentos comerciais e prestadores de serviços: os gerados nessas atividades, excetuados os referidos nas alíneas b, e, g, h e j;

e) resíduos dos serviços públicos de saneamento básico: os gerados nessas atividades, excetuados os referidos na alínea c;

f) resíduos industriais: os gerados nos processos produtivos e instalações industriais.

g) resíduos de serviços de saúde: os gerados nos serviços de saúde, conforme definido em regulamento ou em normas estabelecidas pelos órgãos do Sisnama e do SNVS;

h) resíduos da construção civil: os gerados nas construções, reformas, reparos e demolições de obras de construção civil, incluídos os resultantes da preparação e escavação de terrenos para obras civis;

i) resíduos agrossilvopastoris: os gerados nas atividades agropecuárias e silviculturais, incluídos os relacionados a insumos utilizados nessas atividades;

j) resíduos de serviços de transportes: os originários de portos, aeroportos, terminais alfandegários, rodoviários e ferroviários e passagens de fronteira; 
k) resíduos de mineração: os gerados na atividade de pesquisa, extração ou beneficiamento de minérios.

A Figura 3.3 apresenta um digrama de blocos que mostra as diferentes classificações dos resíduos sólidos, quanto à sua origem.

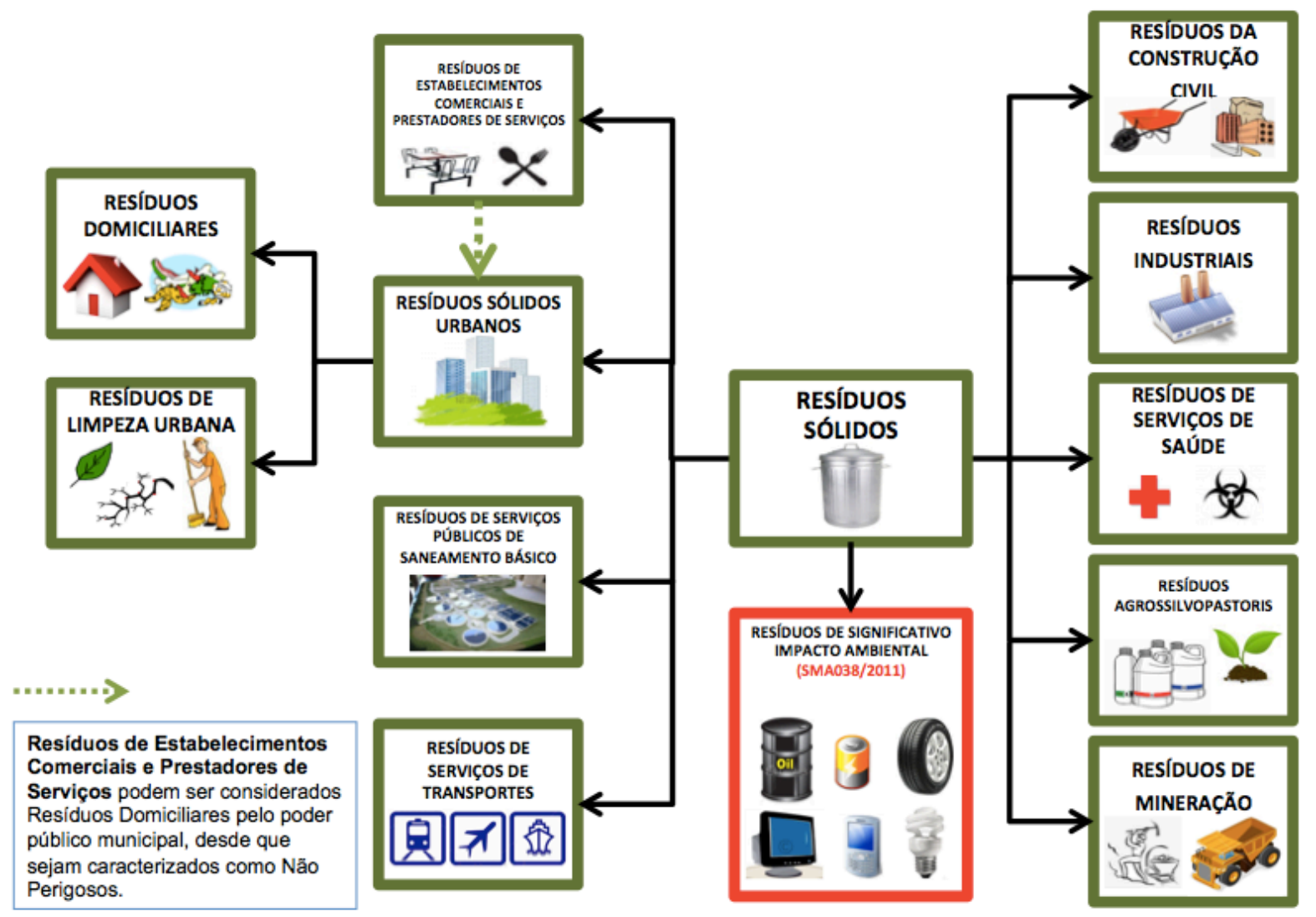

Figura 3.3 - Classificação dos resíduos sólidos quanto a origem Fonte: Schalch et al. (2011)

Com relação à periculosidade, a NBR 10004 define os resíduos perigosos como aqueles que se caracterizam pela letalidade, não - degradabilidade e pelos efeitos cumulativos diversos, os dividindo de acordo com a seguinte classificação:

- Resíduos Classe I - Perigosos: apresentam pelo menos uma das seguintes características: inflamabilidade, corrosividade, reatividade, toxicidade ou patogenicidade;

- Resíduos Classe II - Não Perigosos:

- Classe II A - Resíduos Não Inertes: como, por exemplo, resíduos domiciliares;

- Classe II B - Resíduos Inertes: como, por exemplo, frações minerais de resíduos de construção. 
Já a classificação mais atual, definida pela PNRS, classifica os resíduos sólidos apenas como não perigosos e perigosos, sendo estes definidos como aqueles que em razão de suas características de inflamabilidade, corrosividade, reatividade, toxicidade, patogenicidade, carcinogenicidade, teratogenicidade $e$ mutagenicidade, podem apresentar significativo risco à saúde pública ou à qualidade ambiental, de acordo com lei, regulamento ou norma técnica (BRASIL, 2010).

\subsection{Panorama da destinação final de EVAs no Brasil e no mundo}

Após a compreensão dos conceitos e definições que dizem respeito às EVAs, apresenta-se a seguir o panorama da destinação final das mesmas no Brasil e no mundo.

Em 1999, a Associação Nacional de Defesa Vegetal (Andef) realizou uma pesquisa e identificou que $50 \%$ de todas as embalagens vazias de agrotóxicos no Brasil eram doadas ou vendidas sem nenhum controle; $25 \%$ eram queimadas a céu aberto; $10 \%$ eram armazenadas em locais não adequados, expostos ao meio ambiente; e $15 \%$ eram, simplesmente, abandonadas no campo (BARREIRA; PHILLIPI JUNIOR, 2000).

No entanto, um estudo setorial realizado em 2012 pelo Banco Nacional de Desenvolvimento Econômico e Social (BNDES) mostrou que, a partir da promulgação da Lei 9974 de 2004 e da consequente criação do inpEV, a quantidade de EVAs devolvidas teve um aumento significativo no país. Segundo informações do inpEV, o Brasil alcançou uma taxa de recolhimento de 94\% em 2010, ficando à frente de países como Alemanha (76\%) e Estados Unidos (33\%) (SILVA; COSTA, 2012), como mostra a Figura 3.4. 


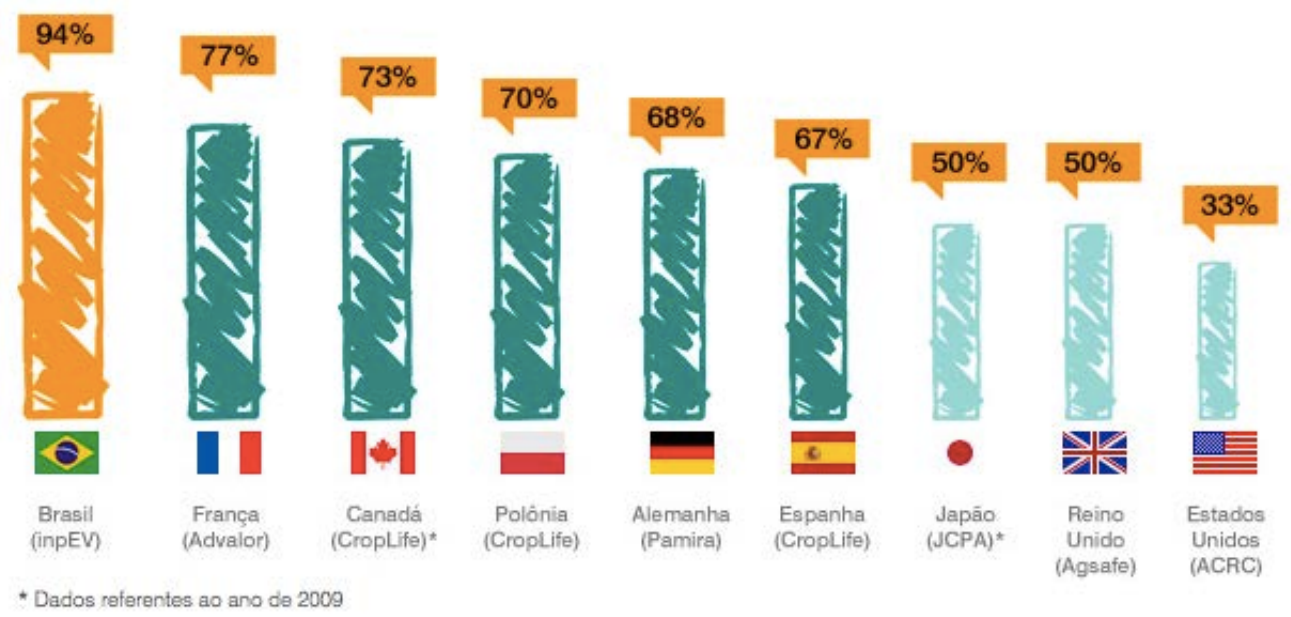

Figura 3.4 - Porcentagem de EVAs destinadas corretamente por país Fonte: inpEV (2011)

Na Tabela 3.1 é apresentado o histórico de devolução das EVAs no país de 2010 a 2014. Em 2014 foram recolhidas 42,646 t de embalagens vazias de agrotóxicos no Brasil, resultado 6\% superior às 40,404 t registradas em 2013 e 13\% superior as 37,379 t recolhidas em 2012 (INPEV, 2013, 2014a, 2015).

Tabela 3.1 - Quantidade de embalagens vazias de agrotóxicos (EVAs) devolvidas por ano no Brasil $201020112012 \quad 2013 \quad 2014$

\begin{tabular}{lccccc}
\hline Embalagens destinadas (mil t) & 31,2 & 34,2 & 37,2 & 40,4 & 42,6 \\
\hline \% de embalagens primárias destinadas & 94 & 94 & 94 & 94 & 94 \\
\hline \% de embalagens secundárias destinadas & 80 & 80 & 80 & 80 & 80 \\
\hline \multicolumn{5}{c}{ Fonte: Modificado de inpEV (2013; 2014; 2015) }
\end{tabular}

Nota-se um aumento gradativo da quantidade de EVAs recolhidas. No entanto, observa-se que a porcentagem de recolhimento permanece a mesma em todos os anos, inclusive quando consideramos as embalagens secundárias (as que não entram em contato com o produto, principalmente papelão).

Do total de EVAs devolvidas em 2014, 91\% foram recicladas e os $9 \%$ restantes foram incinerados, sendo este valor correspondente a compostos de materiais flexíveis que condicionam produtos não miscíveis em água, ou a embalagens que não foram corretamente lavadas pelos produtores (INPEV, 2015).

A Figura 3.5 apresenta a quantidade de EVAs recolhidas por região do país, onde a Centro-Oeste é a que se destaca, com uma taxa de recolhimento correspondente a 40,4\% do total de EVAs. Já a região que possui a menor taxa de 
recolhimento é a Norte, que é também a menos favorecida quanto à quantidade de centrais e postos de recolhimento (Figura 3.5).

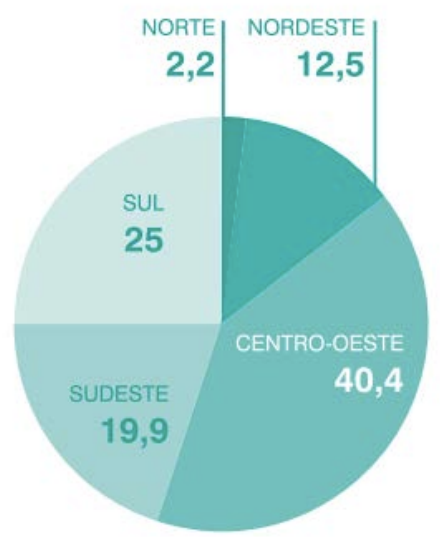

Figura 3.5 - Destinação de embalagens vazias de agrotóxicos (EVAs) no Brasil, por região, em 2014 (\%) Fonte: inpEV (2015)

A partir desses dados, fica clara a importância da logísitica reversa de EVAs como arranjo para a destinação final das mesmas, que só foi efetivamente elaborada e praticada após a criação dos instrumentos legais apresentados a seguir.

\subsection{Instrumentos legais relacionados ao uso de agrotóxicos e às EVAs no Brasil}

O uso de agrotóxicos e afins é uma questão que envolve extrema responsabilidade por parte de todos que participam de alguma maneira do ciclo de vida desses produtos. Sendo assim, é necessário que haja uma legislação rigorosa que direcione, ajude e responsabilize os atores dessa complexa cadeia de produção agropecuária, como pesquisadores, fabricantes, técnicos, produtores rurais e aplicadores do produto (SILVA JÚNIOR, 2008).

No Brasil, os agrotóxicos foram citados numa legislação, pela primeira vez, em 1934, com a aprovação do Regulamento de Defesa Sanitária Vegetal, regulamentado por meio do Decreto 24.114 de 1934. Inicialmente, esses produtos eram denominados "defensivos agrícolas", e conceituados como "químicos caracterizados como inseticidas e fungicidas" (BRASIL, 1934).

Com o auge da revolução verde no Brasil, na década de 1970, houve uma guinada no uso dos agrotóxicos. Assim, em 1976 foi promulgada a Lei 6.360, que 
dispunha sobre a vigilância sanitária a que ficavam sujeitos esses insumos. A partir dessa lei, o Ministério da Saúde passou a opinar no registro desses produtos, iniciando a preocupação com a saúde pública relacionada ao uso de agrotóxicos (BRASIL, 1976; COMETTI, 2009).

Após a criação dessa lei, a legislação foi sendo atualizada, por meio de inúmeras portarias (TAVELLA, 2011), e a recorrente necessidade de seu aperfeiçoamento e do fortalecimento dos serviços dos órgãos responsáveis pelo controle desses insumos fez surgir a Lei 7.802 de 11 de julho de 1989, conhecida como "Lei de Agrotóxicos" (COMETTI, 2009). Esta foi a primeira lei que especificamente dispôs sobre o uso de agrotóxicos no país. Regulamentada pelo Decreto 98.816 de 1990, tratava desde a pesquisa, a experimentação, a fabricação, o registro, até sua comercialização, aplicação, controle, fiscalização dos agrotóxicos, seus componentes e afins (BRASIL, 1989).

Em 2000, a "Lei de Agrotóxicos" foi alterada pela Lei 9.974 e regulamentada pelo Decreto Federal 4.074 no ano de 2002. O caráter inovador dessa mudança foi a determinação das responsabilidades e das competências legais relacionadas à destinação final das embalagens vazias de agrotóxicos.

Para atender às determinações da lei 9974 de 2000, foi então criado em 2001 o Instituto Nacional de Processamento de Embalagens Vazias (inpEV), entidade sem fins lucrativos, resultante da união das indústrias produtoras de agrotóxicos com a função de coordenar a logística reversa de EVAs no Brasil, através do sistema de gestão denominado Sistema Campo Limpo (SCL).

Após a criação do inpEV, foi promulgada a resolução do Conselho Nacional do Meio Ambiente (Conama) no 334 de 2003, que define os procedimentos de licenciamento ambiental dos estabelecimentos destinados ao recebimento de embalagens vazias de agrotóxicos, sendo estes coordenados pelo Sistema Campo Limpo (BRASIL, 2003).

Por se tratar de resíduos perigosos, é relevante ressaltar a existência da Lei 9605 de 1998, que determina as sanções penais e administrativas derivadas de condutas e atividades lesivas ao meio ambiente (BRASIL, 1998). Essa lei é importante, pois classifica a ação irresponsável, seja o uso abusivo de agrotóxicos ou o descarte inadequado de EVAs, como crime ambiental, passível de penalidades como multa e até mesmo reclusão. 
Em 2010 ocorreu um dos marcos legais mais importantes no setor de resíduos sólidos no país: a promulgação da Política Nacional de Resíduos Sólidos (PNRS). A importância maior desta lei foi institucionalizar a logística reversa e a responsabilidade compartilhada, duas ferramentas fundamentais para a gestão das EVAs e de outros resíduos.

\subsubsection{A política Nacional de Resíduos Sólidos (PNRS) e o Plano Municipal de} Gestão Integrada de Resíduos Sólidos (PMGIRS)

Após quase vinte anos de tramitação no Congresso Nacional, a PNRS foi promulgada por meio da Lei 12.305 de 2 de agosto de 2010 e regulamentada em dezembro do mesmo ano, através do Decreto 7404 de 2010. No entanto, um longo caminho foi percorrido para se chegar até o esse momento.

Tudo teve início em 1991, a partir da elaboração do projeto de Lei 203, que dispõe sobre acondicionamento, coleta, tratamento, transporte e destinação dos resíduos de serviços de saúde. Com isso, surgem várias discussões a respeito do tema resíduos sólidos no país. Surge a Proposição Conama 259 de 30 de junho de 1999, intitulada Diretrizes Técnicas para a Gestão de Resíduos Sólidos, que foi aprovada pelo plenário do conselho, mas não chegou a ser publicada (MINISTÉRIO DO MEIO AMBIENTE - MMA, 2014).

Já em 2001, a Câmara dos Deputados criou e implementou a Comissão Especial da Política Nacional de Resíduos com o objetivo de apreciar as matérias contempladas nos projetos de lei anexados ao Projeto de Lei 203 de 1991 e formular uma proposta substitutiva global. Mas, com o encerramento da legislatura, a Comissão foi extinta e apenas em 2003 foi instituído um novo grupo, a fim de promover a integração das ações de saneamento ambiental, no âmbito do governo federal.

O grupo passou a ser denominado Grupo de Trabalho Interministerial de Saneamento Ambiental GT e foi responsável pela reestruturação do setor de saneamento, resultando na criação do Programa Resíduos Sólidos Urbanos. Em 2004, o MMA promove grupos de discussões interministeriais e de secretarias do ministério para elaboração de proposta para a regulamentação dos resíduos sólidos. 
Assim, em 2005 foi encaminhado o anteprojeto de lei de "Política Nacional de Resíduos Sólidos" (MMA, 2014).

Outro passo importante aconteceu em 2007, com a proposição do PL 1991 (projeto de lei da Política Nacional de Resíduos Sólidos), que considerou que o estilo de vida da sociedade contemporânea, aliado às estratégias de marketing do setor produtivo, leva a um consumo intensivo provocando uma série de impactos ambientais, à saúde pública e sociais.

Este projeto de lei tinha extrema relevância, uma vez que foi elaborado considerando forte inter-relação com outros instrumentos legais, tais como a Lei de Saneamento Básico (Lei 11.445 de 2007), Lei dos Consórcios Públicos (Lei 11.107 de 2005), bem como às Políticas Nacionais de Meio Ambiente, de Educação Ambiental, de Recursos Hídricos, de Saúde Urbana, Industrial, Tecnológica e de Comércio Exterior, e as demais legislações que versam sobre inclusão social.

Em 2010, o plenário da Câmara dos Deputados aprovou em votação simbólica um substitutivo ao Projeto de Lei 203 de 1991, do Senado, que instituiu a Política Nacional de Resíduos Sólidos, impondo obrigações aos empresários, aos governos e aos cidadãos no gerenciamento dos resíduos.

Esse foi um enorme passo político e judicial para a gestão e o gerenciamento dos resíduos sólidos no Brasil. Anteriormente a isso, percebe-se que a maioria das administrações públicas optava por eliminar seus resíduos em aterros, dando ênfase a gestão da coleta, transporte e disposição de resíduos no solo, o que não é um meio sustentável de destinação adequada (CÓRDOBA, 2014).

Assim, apesar de a PNRS ainda apresentar grandes desafios econômicos e operacionais, ela fomenta importantes modificações estruturais, culturais e sociais no manejo de resíduos sólidos tais como:

- Incentivo à não geração, redução, reutilização, tratamento e disposição final adequada dos rejeitos o primordial deles.

- Valorização dos catadores;

- Disposição final ambientalmente adequada dos rejeitos;

- Identificação dos resíduos sólidos gerados;

- Incentivo à criação de consórcios intermunicipais que envolvam resíduos sólidos;

- Acordos setoriais; 
- Logística reversa e responsabilidade compartilhada pelo ciclo de vida dos produtos (BRASIL, 2010).

Já os Planos Municipais de Gestão Integrada de Resíduos Sólidos (PMGIRS) são documentos que contém as informações necessárias para direcionar o gerenciamento de resíduos de um dado município. O conteúdo mínimo dos planos está descrito no Art. 19 da PNRS, e no Decreto 7.404 de 2010 é apresentado o conteúdo mínimo no Art. 51, simplificado em 16 itens, a serem adotados nos planos de municípios com população até 20 mil habitantes.

Os municípios podem optar por inserir o PMGIRS no Plano de Saneamento Básico, integrando-o aos planos de água, esgoto e drenagem urbana, como previsto na Lei 11.445 de 2007 (BRASIL, 2007). Sendo assim, o conteúdo mínimo definido em ambos os documentos legais deve ser respeitado. Para os municípios que optarem por soluções consorciadas intermunicipais para gestão dos resíduos sólidos não há a necessidade de elaboração do PMGIRS.

Outro ponto importante a ser destacado tange a prioridade de acesso aos recursos da União. Segundo determinação da PNRS, a elaboração dos PMGIRS é condição necessária para o Distrito Federal e os municípios terem acesso a esses recursos, destinados à limpeza urbana e ao manejo de resíduos sólidos (BRASIL, 2010).

O benefício por incentivos ou financiamentos de entidades federais de crédito ou fomento serão primeiramente disponibilizados para municípios que optarem por soluções consorciadas intermunicipais, incluída a elaboração e implementação de plano intermunicipal, ou que se inserirem de forma voluntária nos planos microrregionais de resíduos sólidos e para municípios que implantarem a coleta seletiva com a participação de cooperativas ou outras formas de associação de catadores de materiais reutilizáveis e recicláveis formadas por pessoas físicas de baixa renda.

De acordo com o Artigo 19 da PNRS, o plano municipal de gestão integrada de resíduos sólidos deve ter o seguinte conteúdo mínimo:

- Diagnóstico (origem, volume, caracterização dos resíduos e as formas de destinação e disposição finais adotadas);

- Identificação de áreas favoráveis para disposição final ambientalmente adequada de rejeitos; 
- Identificação das possibilidades de implantação de soluções consorciadas ou compartilhadas com outros municípios;

- Identificação dos resíduos sólidos e dos geradores sujeitos a plano de gerenciamento específico nos termos do art. 20 ou a sistema de logística reversa;

- Procedimentos operacionais e especificações mínimas;

- Indicadores de desempenho operacional e ambiental dos serviços públicos de limpeza urbana e de manejo de resíduos sólidos;

- Regras para o transporte e outras etapas do gerenciamento de resíduos sólidos;

- Definição das responsabilidades quanto à sua implementação e operacionalização;

- Programas e ações de capacitação técnica voltados para sua implementação e operacionalização; programas e ações de educação ambiental que promovam a não geração, a redução, a reutilização e a reciclagem de resíduos sólidos; programas e ações para a participação dos grupos interessados, em especial das cooperativas ou outras formas de associação de catadores de materiais reutilizáveis e recicláveis formadas por pessoas físicas de baixa renda, se houver;

- Mecanismos para a criação de fontes de negócios, emprego e renda, mediante a valorização dos resíduos sólidos;

- Sistema de cálculo dos custos da prestação dos serviços públicos de limpeza urbana e de manejo de resíduos sólidos, bem como a forma de cobrança desses serviços, observada a Lei no 11.445 , de 2007;

- Metas de redução, reutilização, coleta seletiva e reciclagem, entre outras, com vistas a reduzir a quantidade de rejeitos encaminhados para disposição final ambientalmente adequada;

- Descrição das formas e dos limites da participação do poder público local na coleta seletiva e na logística reversa, respeitado o disposto no art. 33, e de outras ações relativas à responsabilidade compartilhada pelo ciclo de vida dos produtos; 
- Meios a serem utilizados para o controle e a fiscalização, no âmbito local, da implementação e operacionalização dos planos de gerenciamento de resíduos sólidos;

- Ações preventivas e corretivas a serem praticadas, incluindo programa de monitoramento;

- Identificação dos passivos ambientais relacionados aos resíduos sólidos, incluindo áreas contaminadas, e respectivas medidas saneadoras;

- Periodicidade de revisão, observando prioritariamente o período de vigência do plano plurianual municipal.

Esses direcionamentos são o primeiro passo para a implantação dos PMGIRS, que engloba os mais diversos tipos de resíduos e por isso deve levar em conta as particularidades de cada município ou região (o caso dos consórcios), como características culturais e de geração de renda.

No caso das EVAs, é uma ferramenta essencial para o alinhamento e construção de metas a partir de um diagnóstico apurado da geração e fluxo desses resíduos nos municípios. Assim, os PMGIRS devem contribuir com o direcionamento das mudanças necessárias para a melhoria da logística reversa das EVAs.

\subsubsection{Instrumentos legais a nível estadual}

Em nível estadual, em Minas Gerais, os primeiros instrumentos legais ligados à questão dos agrotóxicos foram o Decreto Estadual no 23.698, de 23 de julho de 1984 e a Lei 9.121 de 30 de dezembro de 1985. O decreto dispunha sobre a criação do Conselho Estadual de Agrotóxicos e Biocidas, e a Lei foi responsável por regulamentar o uso de agrotóxicos e biocidas no Estado de Minas Gerais.

Mas foi em dezembro de 1991 o surgimento de diretrizes mais completas a respeito da produção, comercialização e uso de agrotóxico e afins no estado de Minas Gerais, por meio da Lei 10545/1991. O Decreto Estadual no 33.945, de 18 de setembro de 1992, regulamentou totalmente esta Lei, e foi posteriormente substituído pelo Decreto Estadual no 41.203, de 08 de agosto de 2000, que ainda vigora (MINAS GERAIS, 1985; 1991; 2009). 
Esses instrumentos são importantes, pois consideram o contexto do estado de Minas Gerais e são atrelados a outras deliberações estaduais que contribuem para o ato fiscalizatório e punitivo.

A Deliberação Normativa COPAM nำ 74, de 9 de setembro de 2004, por exemplo, estabelece critérios para a classificação, segundo o porte e potencial poluidor, de empreendimentos e atividades modificadoras do meio ambiente passiveis de autorização ambiental de funcionamento ou de licenciamento ambiental no nível estadual, tais como as revendas de agrotóxicos e as centrais de recolhimento de EVAs (MINAS GERAIS, 2004a). As normas para registro de estabelecimento de agrotóxicos e afins, armazenamento, exposição, comercialização de agrotóxico e afim e destinação de suas embalagens vazias são designadas pela Portaria no 862 de 29 de agosto de 2007 (MINAS GERAIS, 2007a).

No quesito regularização ambiental de estabelecimentos que comercializam produtos agrotóxicos, deve-se consultar a Deliberação Normativa COPAM nํㅜ 109, de 30 de maio de 2007, que, além disso, altera o Anexo I da Deliberação Normativa do COPAM nº 74/2004 (MINAS GERAIS, 2007b) e a Portaria nº 650 de 16 junho de 2004, responsável por regularizar o cadastro de agrotóxicos e afins destinados ao uso nos setores de produção agropecuária, no armazenamento e beneficiamento de produtos agrícolas, nas pastagens, agroindústrias e na proteção de florestas no Estado de Minas Gerais (MINAS GERAIS, 2004b).

\subsection{A logística reversa e a gestão de EVAs no Brasil}

Após a instituição da Lei 9.974 de 2000 e da promulgação da PNRS em 2010, o delineamento da logísitica reversa de EVAs finalmente se tornou sólido. No entanto, para compreendê-lo e aplicá-lo, é necessário o conhecimento sobre o conceito de logística reversa, bem como sobre o fluxo de funcionamento da mesma.

Para tanto, inicialmente é importante conhecer a definição de logística, que pode ser entendida como todo o processo que envolve o movimento de bens físicos de um local para outro, sendo o transporte uma parte substancial deste serviço (KRUMWIEDE; SHEU, 2002). Trata-se de um processo que envolve o fluxo de bens e informações da fonte ao consumidor, através do gerenciamento de materiais e 
funções de movimentação, em toda a organização e seus canais de fornecimento (HUGHES et al. ${ }^{7}, 1998$ apud RITCHIE et al., 2000).

Inicialmente, o processo de logística estava basicamente atrelado à contenção e redução de gastos. No entanto, Bowersox e Closs (1996) afirmam que grande parte da importância da logística advém da capacidade de dar às organizações uma vantagem competitiva, oferecendo aos clientes um serviço superior, por meio da disponibilidade de estoque, e da velocidade e consistência de entrega (RITCHIE et al., 2000). Além disso, a logística evoluiu no sentido de considerar em seu delineamento questões ambientais e de responsabilidade social.

Mutha e Pokharel (2009), afirmam que a implementação de legislações, a responsabilidade social, a promoção e manutenção da imagem corporativa, a valorização e dispersão dos conceitos ambientais, bem como os benefícios econômicos e a consciência de consumo (consumo responsável) dos clientes são os principais fatores não só para fornecer produtos ecologicamente fabricados, mas também para levar novamente para a cadeia produtiva aqueles que já estão no fim de seu ciclo de vida.

A utilização de embalagens retornáveis ou o reaproveitamento de materiais em processos produtivos tem proporcionado economia para as empresas que utilizam estas práticas, o que vem cada vez mais despertando interesse em adotálas (LACERDA ${ }^{8}, 2002$ apud COSTA; VALLE, 2006).

Assim, a logística também passou a englobar o fluxo reverso de materiais, ou seja: materiais que vão do usuário final, ou de outro ponto anterior, a um novo consumo ou reaproveitamento. Essa necessidade de reutilização ou de reciclagem de um estoque indesejado, se tornou uma questão importante, e o processo para alcançar isto foi, por razões óbvias, rotulado como "logística reversa" (RITCHIE et al., 2000).

Cabe mencionar que o reaproveitamento de materiais e produtos, como a reutilização parcial de equipamentos, não é uma prática nova. Primeiramente, a motivação para tal prática foi a escassez de recursos materiais. No entanto, o surgimento de materiais baratos e o avanço tecnológico proporcionaram à sociedade maiores condições de consumo, 0 que fez surgir a rotina do descarte, sem que houvesse preocupação com aspectos ambientais. Deste modo, os aterros sanitários tornaram-se dispendiosos e começaram a surgir restrições quanto a degradação do meio

\footnotetext{
${ }^{7}$ HUGHES, J.; RALF, M.; MICHELS, B. Transform your supply chain. International Thomson. London, 1998.

${ }^{8}$ LACERDA, L. Logística reversa. Uma visão sobre os conceitos básicos e as práticas operacionais. 2002. Disponível em:<>. Acesso em: 10 agos. 2014.
} 
ambiente. No mundo empresarial, começou-se a perceber o quanto poderia ser rentável a recuperação de produtos e como esta operação agregaria valor em relação aos aspectos ambientais, competição de mercado e imagem corporativa (COSTA; VALLE, 2006, p.1).

A logística reversa faz parte da logística empresarial, e pode ser definida como o processo de planejamento, operação e controle do fluxo e das informações logísticas correlatas ao retorno dos bens de pós-vendas e de pós-consumo ao ciclo de negócios ou ao ciclo produtivo, por meio dos canais de distribuição reversos, agregando-lhes valor de diversas naturezas: econômica, ecológica, legal, logístico, de imagem corporativa, entre outros (LEITE ${ }^{9}, 2003$ apud COMETTI, 2009).

Cometti e Alves (2010) afirmam que logística reversa é uma ferramenta que pode contribuir para o Desenvolvimento Sustentável, pois, ao promover a internalização dos custos, começam a incorporar as preocupações ambientais em suas decisões econômicas e a investir no desenvolvimento e na transferência de tecnologia que permita agregar valor aos seus produtos ou embalagens após a utilização pelo consumidor.

Do ponto de vista social, a atividade de logística reversa pode gerar novos empregos, ao criar canais de distribuição reversos. Economicamente, possibilita a reciclagem e comercialização desses novos produtos. Culturalmente, cria uma responsabilidade individual pelo resíduo gerado e proporciona um cuidado maior pelo usuário (COMETTI; ALVES, 2010).

Assim, a responsabilização pós-consumo torna-se um incentivo ao uso de materiais mais "ecológicos" no processo de produção, à redução da produção de resíduos e de seu custo de disposição, bem como do consumo de matéria-prima; à melhoria no desenvolvimento do produto aumentando sua utilidade e tempo de uso; e a criação de sistemas de reciclagem mais eficientes (COMETTI; ALVES, 2010; MUELLER, 2005).

No Brasil, a preocupação em implantar a logística reversa em vários segmentos industriais cresceu a partir da década de 1980, diante do enorme crescimento da quantidade de lixo nos centros urbanos, o que, por sua vez, tinha ligação direta com a proliferação de embalagens e produtos descartáveis. Esse momento coincidiu ainda com o despertar da conscientização da sociedade brasileira quanto à necessidade de preservação ambiental, o que se refletiu na definição de novas políticas governamentais e também empresariais (INPEV, 2014b).

Legalmente, a logística reversa foi instituída no Brasil em 2010, por meio da PNRS. Esta define a mesma como um

\footnotetext{
9 LEITE, P.R. Logística reversa: meio ambiente e competitividade. São Paulo: Prentice Hall, 2003.
} 
instrumento de desenvolvimento econômico e social caracterizado por um conjunto de ações, procedimento e meios destinados a viabilizar a coleta e a restituição dos resíduos sólidos ao setor empresarial, para reaproveitamento, em seu ciclo ou em outros ciclos produtivos, ou outra destinação final ambientalmente adequada (BRASIL, 2010).

Sendo assim, a logística reversa de resíduos sólidos foi desenhada para prevenir a geração dos mesmos ao invés de apenas construir mais instalações para disposição final desses resíduos. Reciclar se tornou uma prioridade, e a disposição em aterros sanitários é ambientalmente aceitável apenas para rejeitos (VEIGA, 2013).

De acordo com Decreto $n^{0}$ 7.404/2010, os sistemas de logística reversa serão implementados e operacionalizados por meio dos seguintes instrumentos:

I - acordos setoriais: são atos de natureza contratual, firmados entre o Poder Público e os fabricantes, importadores, distribuidores ou comerciantes, visando a implantação da responsabilidade compartilhada pelo ciclo de vida dos produtos.

II - regulamentos expedidos pelo Poder Público: a logística reversa poderá ser implantada diretamente por regulamento, veiculado por decreto editado pelo Poder Executivo. Antes da edição do regulamento, o Comitê Orientador deverá avaliar a viabilidade técnica e econômica da logística reversa. Aqueles que forem estabelecidos diretamente por decreto deverão ainda ser precedidos de consulta pública.

III - termos de compromisso: o Poder Público poderá celebrar termos de compromisso com fabricantes, importadores, distribuidores ou comerciantes: desde que não haja em uma mesma área de abrangência, acordo setorial ou regulamento específico; com o objetivo de fixar compromissos e metas mais exigentes que o previsto em acordo setorial ou regulamento.

Além disso, é importante ressaltar que a logística reversa é um dos instrumentos para aplicação da responsabilidade compartilhada pelo ciclo de vida dos produtos. Esta pode ser definida como:

conjunto de atribuições individualizadas e encadeadas dos fabricantes, importadores, distribuidores e comerciantes, dos consumidores e dos titulares dos serviços públicos de limpeza urbana e de manejo dos resíduos sólidos, para minimizar o volume de resíduos sólidos e rejeitos gerados, bem como para reduzir os impactos causados à saúde humana e à qualidade ambiental decorrentes do ciclo de vida dos produtos (BRASIL, 2010). 
Com base nesse conceito, a PNRS definiu em seu Art. 33 que os fabricantes, importadores, distribuidores e comerciantes de agrotóxicos são obrigados a estruturar e implementar sistemas de logística reversa, mediante retorno dos produtos após o uso pelo consumidor, de forma independente do serviço público de limpeza urbana e de manejo dos resíduos sólidos. Como já mencionado, isso é devido ao fato de que as EVAs podem constituir-se como resíduos perigosos e nesse caso oferecem riscos a saúde humana e ambiental.

O processo de logística reversa desses resíduos envolve quatro atores (produtores rurais, revendedores, fabricantes de agrotóxicos e poder público) e cinco etapas imprescindíveis para que seja completamente efetiva: comercialização, tríplice lavagem/lavagem sob pressão, devolução, triagem e reciclagem/incineração. O diagrama apresentado na Figura 3.6 apresenta o fluxo da logística reversa de EVAs.

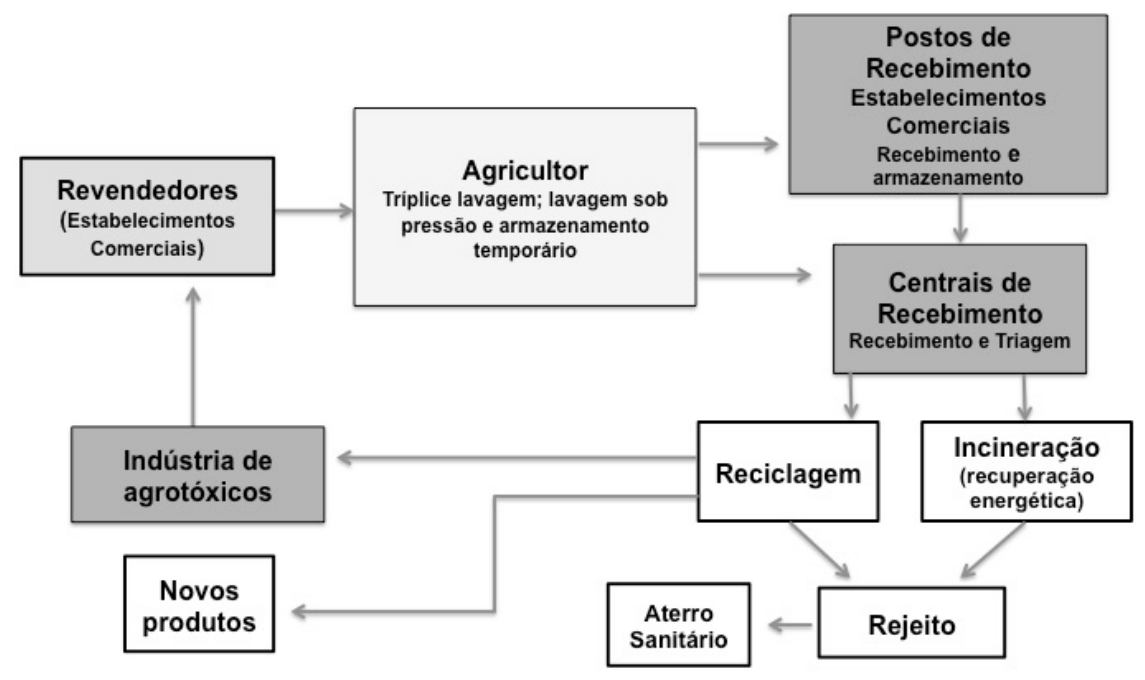

Figura 3.6 - Fluxo da logística reversa de EVAs Fonte: Adaptado de inpEV (2014)

Aos agricultores cabe a responsabilidade de devolver as EVAs nas revendas ou em postos de recolhimento autorizados, devidamente lavadas e acondicionadas. Aos comerciantes, cabe a responsabilidade de construir instalações adequadas em suas revendas ou disponibilizar postos de recebimento para receber e armazenar as embalagens recebidas. Devem também indicar o endereço da unidade de recebimento mais próxima da propriedade do agricultor na nota fiscal, orientando-o quanto à forma e prazo para a entrega (CARBONE; SATO; MOORI, 2005).

Já as empresas produtoras e comercializadoras de agrotóxicos, seus componentes e afins, têm a responsabilidade de dar o destino final adequado às 
embalagens e/ou aos restos de produtos devolvidos pelo usuário, seja por meio de reciclagem, incineração ou outro fim indicado pela tecnologia e amparado legalmente.

O poder público tem como responsabilidade licenciar os as unidades de recebimento e contribuir com programas de educação e conscientização da sociedade (INPEV, 2013). Além disso, é o responsável pela fiscalização de todo o sistema, desempenhando poder de polícia ambiental para que haja o controle da cadeia, tendo em vista a necessidade preventiva ou repressiva diante da possibilidade de danos ao ambiente e à saúde pública (MALINOWSKI; MALINOWSKI, 2011). Um resumo de todas as responsabilidades de cada ator é apresentado na Figura 3.7.

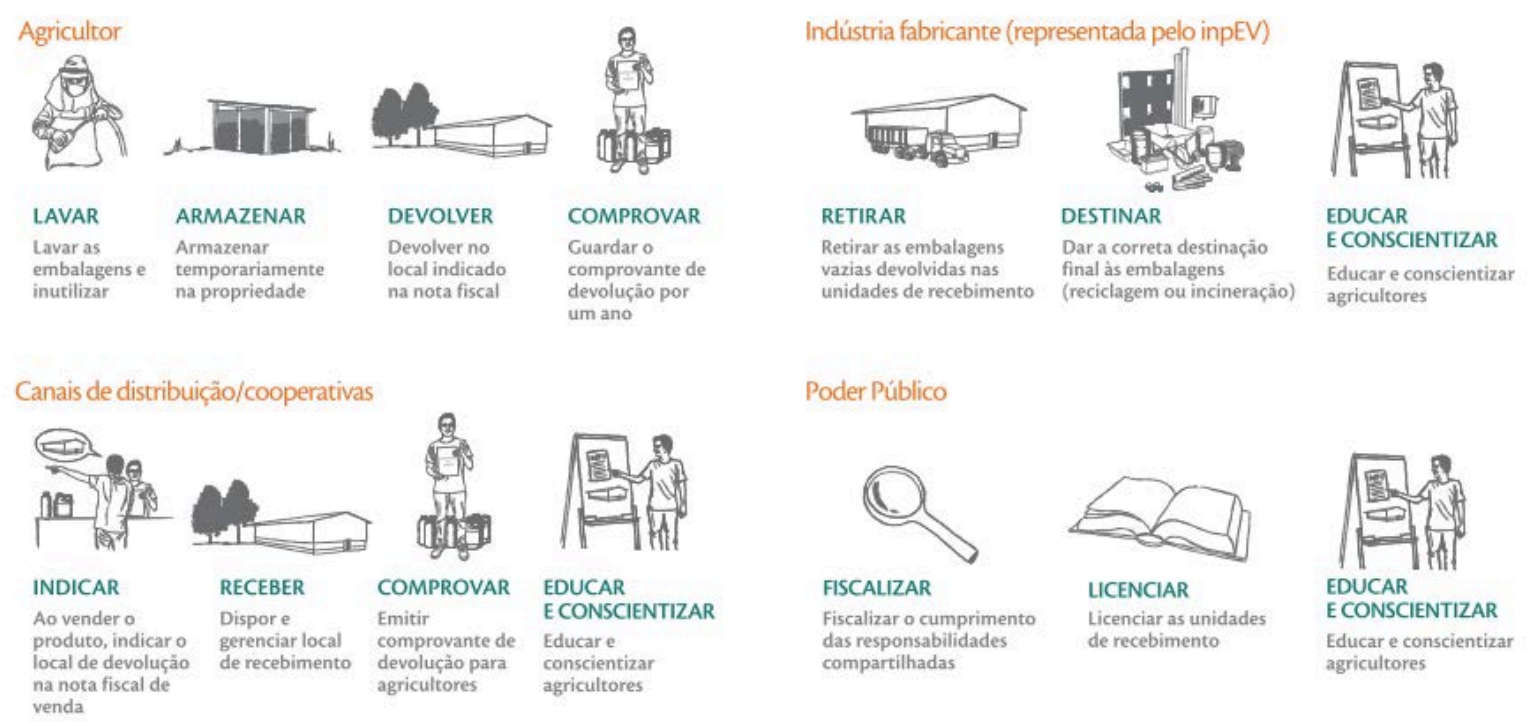

Figura 3.7 - Responsabilidades de cada ator no processo de logística reversa Fonte: inpEV (2014b)

Parte da estrutura necessária para a destinação adequada de EVAs é oferecida pelo Sistema Campo Limpo coordenado pelo inpEV. Este sistema, conta com uma estrutura de $156 \mathrm{mil}^{2}$ de área construída, e já realizou 4,8 mil recebimentos itinerantes. Possui 415 unidades de recebimento, sendo 113 centrais e 302 postos, localizadas em 25 estados do país e no Distrito Federal, como pode ser visto na figura 3.7 (INPEV, 2015). 


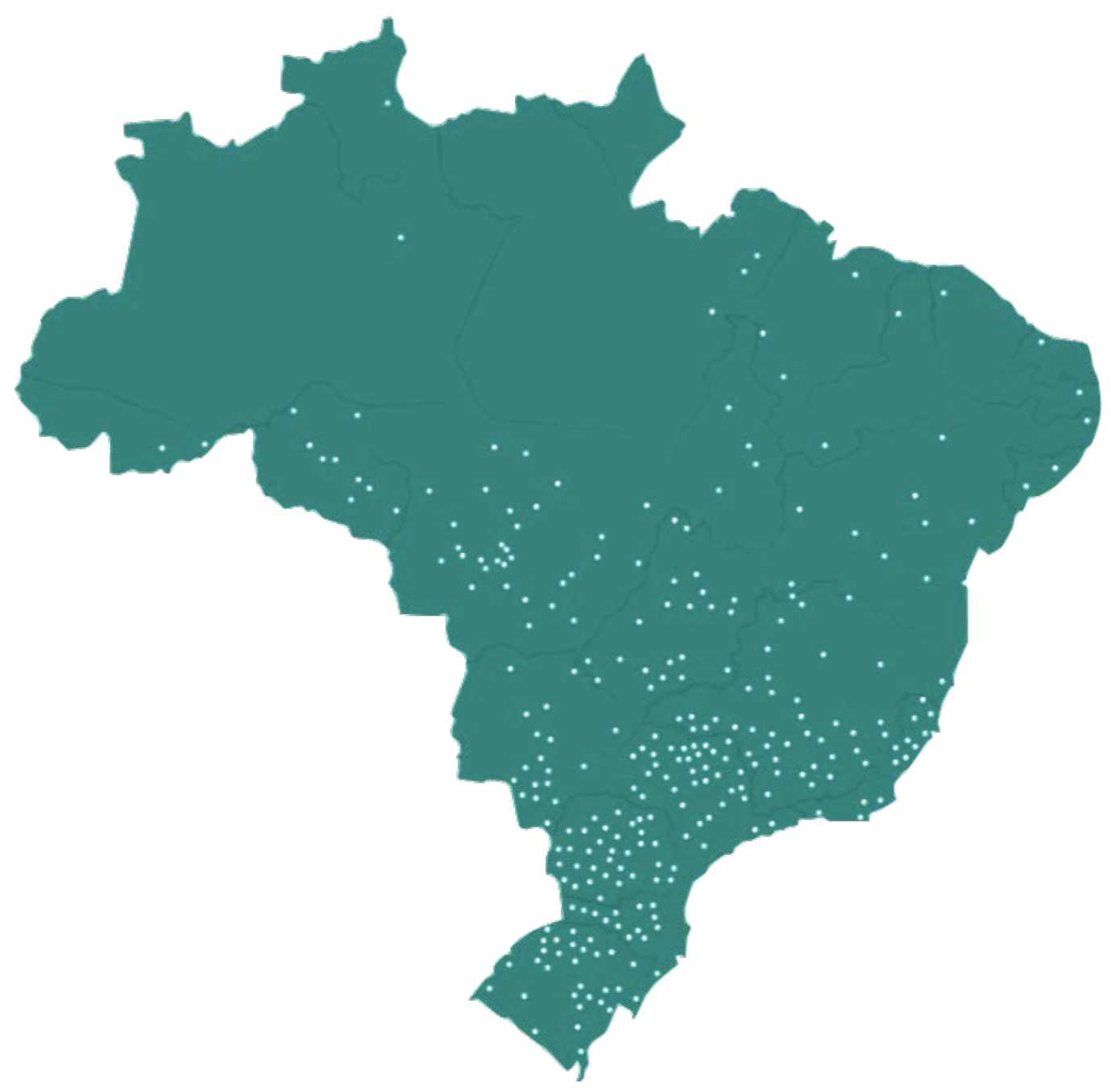

Figura 3.8 - Mapa das unidades de recebimento de EVas nas diferentes regiões do país Fonte: inpEV (2012)

Os postos de recebimento são unidades que se destinam ao recebimento, controle e armazenamento temporário das embalagens vazias de agrotóxicos e afins, até que as mesmas sejam transferidas à central ou diretamente à destinação final ambientalmente adequada. Licenciadas ambientalmente com no mínimo $80 \mathrm{~m}^{2}$ de área construída, são geridas por uma Associação de Distribuidores/Cooperativas responsáveis pelo recebimento de embalagens lavadas e não lavadas; inspeção e classificação das mesmas entre lavadas e não lavadas; emissão de recibo de confirmação de entrega; e encaminhamento das EVAs às centrais de recebimento (BRASIL, 2003; INPEV, 2014c).

Já as centrais de recebimento são licenciadas com no mínimo $160 \mathrm{~m}^{2}$ de área construída e utilizadas para o recebimento, controle, redução de volume, acondicionamento e armazenamento temporário das EVAs. Seu o gerenciamento é 
feito por uma Associação de Distribuidores/Cooperativas com supervisão do inpEV, e realizam os seguintes serviços:

- Recebimento de embalagens lavadas e não lavadas (de agricultores, postos e estabelecimentos comerciais licenciados);

- Inspeção e classificação das embalagens entre lavadas e não lavadas;

- Emissão de recibo de confirmação de entrega das EVAs;

- Separação das embalagens por tipo (PET, COEX, PEAD MONO, metálica, papelão);

- Compactação das embalagens por tipo de material;

- Emissão de ordem de coleta para que o Inpev providencie o transporte para o destino final (reciclagem ou incineração).

\subsection{A gestão de EVAs em outros países}

As embalagens de agrotóxicos não são um problema apenas no Brasil. Outros países apresentam desafios iguais ou maiores na gestão e gerenciamento desses resíduos. Em Al-Batinah, região nordeste do Oman e em Pieria, na Grécia, estudos mostram que não há um gerenciamento organizado das embalagens vazias de agrotóxicos e que os agricultores dessas regiões também possuem o hábito de enterrar, queimar ou simplesmente abandonar as EVAs no campo (AL ZADJALI et al., 2013; DAMALAS; TELIDIS; THANOS, 2008).

Ainda segundo esses estudos, na maioria das vezes, esse comportamento deve-se à falta de orientação técnica e qualificação profissional dos agricultores. Al Zadjali et al. (2013) afirma que o Estado sofre de insuficiência de pessoal e falta de programas de formação, de tal forma que os agricultores agora têm baixa confiança no sistema e tem procurado auxílio e assistência no setor privado, por meio de consultorias.

$\mathrm{Na}$ França, assim como no Brasil, a instituição responsável pelo gerenciamento das EVAs foi criada pela iniciativa privada. A taxa média de coleta nacional é considerada baixa, alcançando apenas $25 \%$ no ano de 2003 , com taxas variáveis entre 5 a 50 por cento entre as localidades. Mas as conquistas não podem ser ignoradas, e num comparativo com o ano de 2002, houve um aumento de $41 \%$ na coleta das EVAs no país. O esquema de logística reversa também é similar ao 
sistema brasileiro, sendo a responsabilidade compartilhada uma característica marcante (FAO, 2008).

Há 3650 estações de coleta em toda a França, onde os agricultores devem destinar suas embalagens devidamente lavadas e armazenadas. Os distribuidores têm de informar aos seus clientes como eliminar os seus recipientes vazios, e organizar e controlar a coleta. Já os produtores de fitofarmacêuticos são responsáveis pelo transporte e pela recuperação dos recipientes, além de fornecer dados científicos a respeito de seus produtos. Os recipientes recolhidos são incinerados, a um custo médio de cerca de $€ 480 /$ tonelada, em fornos de cimento e instalações de incineração de empresas de gestão de resíduos perigosos com recuperação de energia (FAO, 2008).

Já na América do Sul, há também o exemplo chileno, que se destaca pelo excelente programa de treinamento, que capacita tanto agricultores (aplicadores) quanto a rede de vendedores para gerenciar melhor a coleta, o armazenamento e o transporte das EVAs, dando foco principalmente a realização da tríplice lavagem.

Esse é um fator importante, uma vez que, em junho de 2003, o Ministério da Saúde daquele país publicou o "Regulamento Sanitário para a Gestão de Resíduos Perigosos", que afirma no artigo 24 que os recipientes submetidos a tríplice lavagem são classificados como resíduos não-perigosos. O acompanhamento e $\mathrm{o}$ monitoramento das condições de funcionamento dos centros de coleta é realizada pela AFIPA (National Association of Manufacturers and Importers of Crop Protection Products) e autoridades nacionais .

Nos EUA, segundo maior mercado consumidor de agrotóxicos (SINDAG, 2013b), o gerenciamento das EVAs é realizado voluntariamente pela Ag Container Recycling Council (ACRC), uma organização sem fins lucrativos financiada pelas empresas CropLife América e sete outros membros afiliados (EPA, 2012).

Há regulamentações federais e estaduais que caracterizam algumas embalagens de agrotóxicos como resíduos perigosos e dispõe sobre a reciclagem e o descarte das mesmas. Cabe aos governos estaduais regular a queima a céu aberto e a prática de enterrar esses resíduos. Cerca de 3175 toneladas ou cerca de 10 milhões de contêineres por ano são recolhidas nos EUA através da ação da ACRC. Quatro empreiteiras da ACRC são responsáveis por moer os recipientes coletados e enviá-los para empresas de reciclagem que os transformam em outros produtos tais como tubos de drenagem campo (FAO, 2008). 
O sistema de reciclagem da ACRC é financiado por contribuições de membros em proporção ao peso do plástico das embalagens de agrotóxicos colocadas no mercado nos EUA e determinada pelo orçamento total da ACRC. Os agricultores devem levar as EVAs lavadas para locais de coleta, onde são inspecionadas e aceitas gratuitamente. Desde 1993, mais de 65 milhões de libras (29 484 toneladas), ou cerca de 93 milhões de contêineres foram reciclados. O custo total do programa anual é de US\$ 3,9 milhões, dos quais mais de $80 \%$ é gasto na coleta das EVAs (FAO, 2008). 


\section{METODOLOGIA}

\subsection{Abordagem metodológica}

A presente pesquisa é classificada como aplicada, uma vez que possui um caráter prático, em que os resultados adquiridos podem ser utilizados imediatamente na solução de problemas que ocorrem na realidade. Caracteriza-se também como descritiva, pois aborda a descrição, registro, análise e interpretação de fenômenos atuais, com o objetivo de ser aplicada no presente (LAKATOS; MARCONI, 2003).

Sua vertente exploratória advém do levantamento de informações sobre um objeto específico (EVAs e assuntos relacionados), com uma delimitação do campo de trabalho. Já sua vertente explicativa advém do fato de que além dos registros e análises dos fenômenos estudados, busca-se identificar suas causas, através de métodos experimentais/ matemáticos, ou seja, quantitativos, ou pela interpretação possibilitada pelos métodos qualitativos - entrevistas semiestruturadas (SEVERINO, 2007).

\subsection{Caso de Estudo}

O município de Bom Repouso, caso de estudo escolhido para o desenvolvimento da presente pesquisa, é um dos municípios que compõem a bacia hidrográfica da montante do rio Mogi-Guaçu, (Figura 4.1). Classificada como uma bacia de oitava ordem, conta com 20.193 canais e uma área total de drenagem de $17.303 \mathrm{~km}^{2}$, sendo que desta, $2.650 \mathrm{~km}^{2}$ estão no Estado de Minas Gerais e 14.653km² no Estado de São Paulo (GANDOLFI ${ }^{10}, 1971$ apud ESPÍNDOLA, 2011).

No estado de Minas Gerais a Bacia do Rio Mogi-Guaçu abrange dez municípios, com uma população de 155.201 habitantes, sendo eles: Andradas, Albertina, Bom Repouso, Bueno Brandão, Ibitiúra de Minas, Inconfidentes, Jacutinga, Monte Sião, Munhoz e Ouro Fino (NISHIKAWA, 2012).

10 GANDOLFI, N. Investigações sedimentológicas, morfométricas e fisico- químicas nas Bacias do Mogi Guassu, do Ribeira de Iguape e do Peixe. 1971. 108p. Tese (Livre Docência) - Escola de Engenharia de São Carlos, Universidade de São Paulo, São Carlos, 1971. 


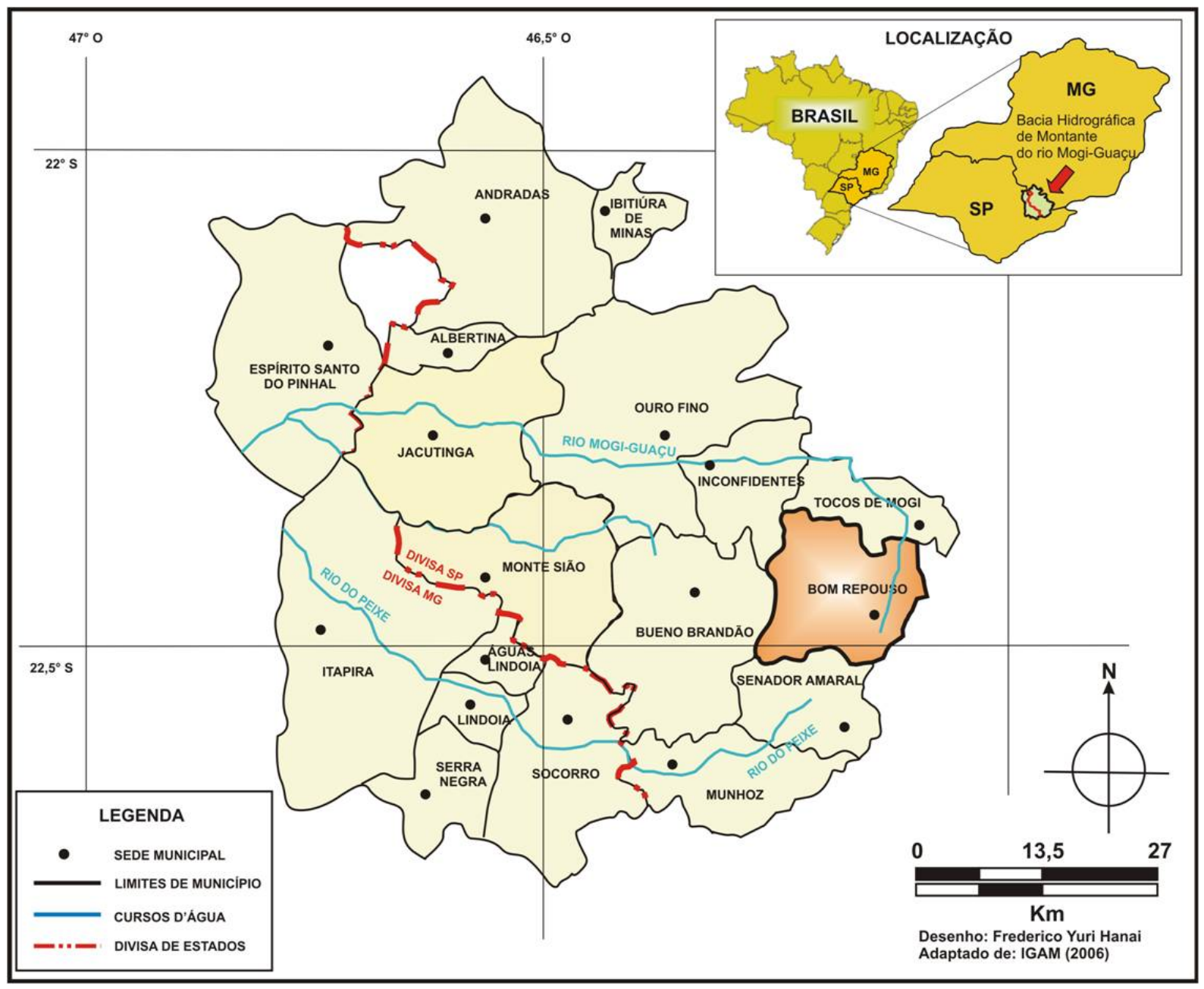

Figure 4.1 - Localização da bacia hidrográfica de montante do rio Mogi-Guaçu e do município de Bom Repouso Fonte: Espíndola e Brigante (2009)

Bom Repouso possui seus limites administrativos na Serra da Mantiqueira, com uma área de unidade territorial de 229,845 km². Famoso pelas atividades agrícolas, o município possui $45,7 \%$ de sua população na área rural e $54.3 \%$ na área urbana (IBGE, 2010). No último censo realizado pelo Instituto Brasileiro de Geografia e Estatística - IBGE em 2010, o município contava com uma população de 10.457 habitantes. A partir de estimativas do mesmo órgão, acredita-se que no ano de 2013 essa população seria de 10.759 habitantes.

A origem e fundação do município não é bem explicada, uma vez que não há qualquer registro oficial sobre esse fato. A existência de uma "fortaleza em ruínas" nas cercanias da cidade, pelo seu estilo e tipo de construção, faz crer que o início da povoação ocorreu nos primórdios da era colonial. Somente apontamentos religiosos, anteriores a 1828, dão conta de que já residiam na localidade os padres Francisco 
Figueira de Assunção, e Florentino José Maria de Medeiros, tidos como primeiros moradores.

[...] As condições climáticas, as propriedades terapêuticas de suas águas e a fertilidade do solo atraíram novos moradores, descendentes de franceses e espanhóis, originando-se as famílias Andradas, Brandões e Garcias. Posteriormente, o incremento à fruticultura, à exploração de tubérculos e madeira, à pecuária e culturas agrícolas em geral, determinaram o desenvolvimento da comunidade (IBGE, 2010).

O município agrega várias riquezas naturais, destacando-se também pelo seu potencial turístico ímpar, principalmente pela beleza de suas cachoeiras e matas. Somente em seus limites municipais foram catalogadas 759 nascentes em uso e prioridades em ordem decrescente para consumo humano, dessedentação de animais e irrigação (CUNHA, 2009).

Com um clima tropical de altitude Cwb com pluviosidade média de $1500 \mathrm{~mm}$ (classificação de Köeppen), seus domínios fitoecológicos são formados, basicamente, por Mata Atlântica e araucárias. Esses domínios estão bastante ameaçados devido à exploração da madeira e do uso de áreas para atividades agrícolas, além da pecuária e criação de pequenos animais (NUNES, 2010).

Bom Repouso destaca-se pela produção de batata-inglesa e morango (possui a lavoura de morangos mais extensa do estado). Também tem sido observado 0 crescimento de lavouras de café, tomate e alho na região. Apesar de ter a economia baseada na agricultura familiar, feita por pequenos produtores, Bom Repouso também desenvolve outras atividades, tais como o artesanato e o ecoturismo (ESPÍNDOLA, 2011; ESPÍNDOLA; BRIGANTE, 2009).

Caracteriza-se como um município carente nos quesitos saneamento (apenas $54,31 \%$ da população total é atendida com serviços de esgotamento sanitário) (SNIS, 2013), saúde e educação, necessitando de melhorias profundas nesses sistemas, principalmente na área rural, onde não há sequer coleta regular de resíduos sólidos domiciliares e a disposição inadequada dos esgotos pela população gera vários agravos de saúde pública e ambiental (CUNHA, 2009; ESPÍNDOLA; BRIGANTE, 2009).

A região onde está localizado compreende, em especial, as micro-bacias do Rio Mogi-Guaçu, Rio Espraiado e Rio do Peixe. Estes banham áreas com forte influência de impactos já efetivos e potencias advindos da ausência e/ou ineficiência 
de planejamento das atividades de uso e ocupação do solo exercidas na bacia, e que têm seus reflexos nos recursos ambientais e na qualidade de vida das populações (ESPÍNDOLA, 2011).

As principais atividades responsáveis pela perda da qualidade ambiental e prejuízo da saúde pública na região são as lavouras tradicionais instaladas em áreas inaptas e em áreas de preservação permanente (APP); o uso intensivo de fertilizantes e agrotóxicos e a má gestão dos resíduos provenientes dessas atividades - destaca-se a queima ou abandono no campo de embalagens vazias de agrotóxicos e fertilizantes; a supressão da mata nativa de encosta e de topo de morros e das áreas que margeiam nascentes e córregos; o uso crescente de sistemas de irrigação que promovem redução da vazão de nascentes e córregos ou mesmo levam ao desaparecimento destes corpos d'água; a disposição inadequada do esgoto sanitário e a falta de orientação e planejamento para evitar os efeitos do turismo de massa (CUNHA, 2009; ESPÍNDOLA, 2011; ESPÍNDOLA; BRIGANTE, 2009; NUNES, 2010).

Como impacto dessas atividades foram identificados níveis crescentes de esgotamento do solo, soterramento de nascentes, assoreamento e contaminação de córregos, e supressão das matas nativas (ESPÍNDOLA; BRIGANTE, 2009). Com relação às contaminações, estas possuem efeitos toxicológicos e de periculosidade ambiental com níveis diferenciados, o que paralelamente à adoção de práticas de produção inadequadas, torna a situação preocupante em termos de saúde ambiental e humana (NUNES, 2010).

Em relação à saúde humana, diferentes estudos realizados na região mostram que intoxicações por agrotóxicos são frequentemente relatadas pela comunidade (CUNHA, 2009; ESPÍNDOLA, 2011; ESPÍNDOLA; BRIGANTE, 2009; NISHIKAWA, 2012; NUNES, 2010).

Nos estudos desenvolvidos por Espíndola e Brigante (2003), os pesquisadores observaram a presença de pesticidas organofosforados nos riachos da região. Além disso, detectaram quantidades preocupantes dos inseticidas parathionetil e metil, o qual é responsável pela ação inibitória da enzima acetilcolinesterase. Este fato indica fortes suspeitas de que esse agrotóxico fosse o responsável pelo aumento de casos de suicídios entre os agricultores locais. Nishikawa (2012) apresenta relatos de produtores rurais de Bom Repouso que afirmam ser alto o consumo de psicotrópicos no município. Além disso, afirmam que 
o índice de contaminação por resíduos de agrotóxico é muito alto na cidade, e por isso acreditam que os vários caso de câncer que ocorrem no município estão diretamente relacionados ao contato com esses resíduos.

A não utilização de receituário agronômico para compra dos produtos; aplicações seguindo calendário pré-definido e não em função da necessidade real; utilização de dosagens ou número de aplicações maiores do que as recomendadas para as culturas; desrespeito aos períodos de carência dos agrotóxicos, aplicandoos inclusive durante a colheita; descuido com a segurança laboral durante as aplicações e queima ou abandono de EVAs no campo são os principais motivos que levam aos problemas ambientais e de saúde pública causados pelo uso de agrotóxicos nesse município (NUNES, 2010).

Com relação à destinação adequada de EVAs, aponta-se como falhas a dificuldade dos produtores para transportar as embalagens até os postos ou centrais de recolhimento, geralmente distantes de suas propriedades, além da falta de conhecimento apropriado dos mesmos sobre o uso adequado de agrotóxicos (manuseio, estocagem e retorno de embalagens vazias). Há falta de comprometimento das autoridades governamentais e do inpEV em disponibilizar uma estrutura estratégica e física adequada para que os produtores possam cumprir com suas reponsabilidades.

\subsection{Desenvolvimento da pesquisa}

Com base no contexto do caso de estudo, a pesquisa foi desenvolvida nas seguintes etapas: (i) revisão bibliográfica, (ii) visitas de campo e (iii) análise comparativa de dados secundários relativos à venda de agrotóxicos e à devolução das EVAs do município de Bom Repouso, como apresentado no Quadro 4.1. 


\begin{tabular}{|c|c|c|c|}
\hline \multicolumn{2}{|r|}{ ETAPA } & OBJETIVO & MÉTODO \\
\hline (i) & $\begin{array}{c}\text { Revisão } \\
\text { Bibliográfica }\end{array}$ & $\begin{array}{l}\text { Compreender o contexto do estudo, } \\
\text { bem como elucidar a importância da } \\
\text { pesquisa e suas contribuições. }\end{array}$ & \begin{tabular}{lrr} 
Pesquisa & bibliográfica: & foram \\
consultados & periódicos & en \\
publicações & \multicolumn{3}{c}{ científicas } \\
consagradas na área de estudo, \\
bem como livros, dissertações, \\
teses e legislações.
\end{tabular} \\
\hline \multirow[b]{2}{*}{ (ii) } & $\begin{array}{l}\text { Visita de campo: } \\
\text { levantamento } \\
\text { documental }\end{array}$ & $\begin{array}{l}\text { Conhecer as legislações municipais e } \\
\text { outros documentos relevantes para o } \\
\text { entendimento da atual gestão de } \\
\text { resíduos do município de Bom } \\
\text { Repouso, MG, principalmente com } \\
\text { relação ao Plano Municipal de } \\
\text { Gestão integrada de Resíduos } \\
\text { Sólidos (PMGIRS). }\end{array}$ & $\begin{array}{l}\text { Levantamento junto à prefeitura } \\
\text { dos documentos e legislações. } \\
\text { Análise por meio da identificação e } \\
\text { interpretação do material obtido. }\end{array}$ \\
\hline & $\begin{array}{l}\text { Visita de campo: } \\
\text { realização e análise } \\
\text { das entrevistas } \\
\text { semi-estruturadas }\end{array}$ & $\begin{array}{l}\text { Compreender a noção e opinião dos } \\
\text { atores envolvidos na cadeia da } \\
\text { logística reversa de EVAs (presidente } \\
\text { do Sindicato de Trabalhadores Rurais } \\
\text { de Bom Repouso, MG; revendedores } \\
\text { de agrotóxicos do município; } \\
\text { responsável pelos assuntos de Meio } \\
\text { Ambiente e presidente do Conselho } \\
\text { Municipal de Meio Ambiente - } \\
\text { Condema - da Prefeitura Municipal } \\
\text { de Bom Repouso; gerente da Central } \\
\text { de Recolhimento de EVAs do inpEV } \\
\text { de Pouso Alegre, MG). }\end{array}$ & $\begin{array}{l}\text { Entrevista com base em um roteiro } \\
\text { pré-elaborado e possibilidade de } \\
\text { intervenção livre nas perguntas e } \\
\text { respostas por parte do } \\
\text { entrevistador e do entrevistado. }\end{array}$ \\
\hline (iii) & $\begin{array}{l}\text { Análise comparativa } \\
\text { de dados } \\
\text { secundários }\end{array}$ & $\begin{array}{l}\text { Diagnosticar a situação do consumo } \\
\text { de agrotóxicos e do recolhimento e } \\
\text { destinação da EVAs do município de } \\
\text { Bom Repouso. }\end{array}$ & $\begin{array}{l}\text { Levantamento e análise de dados } \\
\text { quantitativos secundários sobre a } \\
\text { comercialização de agrotóxicos no } \\
\text { município de Bom Repouso, MG, } \\
\text { fornecidos pelo Instituto Mineiro de } \\
\text { Agropecuária (IMA), e de } \\
\text { devolução de EVAs por produtores } \\
\text { do município, fornecidos pela } \\
\text { Central de recolhimento de EVAs } \\
\text { de Pouso Alegre, MG. }\end{array}$ \\
\hline
\end{tabular}

Quadro 4.1 - Etapas, objetivos e métodos da pesquisa

A primeira etapa consistiu de uma revisão bibliográfica acerca dos diversos temas relacionados às EVAs e ao local de estudo. A revisão foi feita a partir da leitura de artigos científicos, relatórios, livros, legislações, teses, dissertações e outros documentos, e teve o objetivo de compreender o contexto do estudo, bem como elucidar a importância da pesquisa e suas contribuições.

Já na segunda etapa foram realizadas as visitas de campo e o levantamento documental. As visitas ao município de Bom Repouso ocorreram em agosto e novembro de 2014 e novembro de 2015; e à Central de Recolhimento de EVAs de Pouso Alegre, MG, em novembro de 2014. As entrevistas tiveram como base um roteiro pré-elaborado, com possibilidade de intervenção livre nas perguntas e respostas por parte do entrevistador e do entrevistado. Como ferramenta introdutória e de confiabilidade, foram preparadas cartas de apresentação, termo de sigilo de 
informações pessoais, termo de autorização para gravação e termo de autorização para gravação e citação para os entrevistados. Estes documentos estão presentes nos apêndices. Todas as entrevistas foram gravadas e posteriormente transcritas para uma análise mais acurada.

Em Bom Repouso foram entrevistados sete revendedores de agrotóxicos, um representante da Prefeitura Municipal, responsável pelos assuntos de Meio Ambiente e presidente do Conselho Municipal de Meio Ambiente (Condema) e o representante do Sindicato dos Trabalhadores Rurais. Em Pouso Alegre, foi entrevistado o gerente da Central de Recebimento de EVAs do inpEV. Esta é a central mais próxima de Bom Repouso, localizada a aproximadamente $60 \mathrm{~km}$ do município.

Já o levantamento documental foi feito junto à prefeitura do município, onde alguns documentos relacionados a área ambiental e de saúde pública foram disponibilizados. A análise foi feita a partir da identificação e interpretação desses documentos e teve como objetivo conhecer as legislações municipais e outros instrumentos legais relevantes para o entendimento da atual gestão de resíduos do município, principalmente com relação ao Plano Municipal de Gestão Integrada de Resíduos Sólidos (PMGIRS). Sendo assim, com a análise dessas entrevistas e documentos, buscou-se identificar e compreender as possíveis falhas de gestão e também vislumbrar sugestões de melhoria.

$\mathrm{Na}$ terceira etapa foi realizada a análise comparativa dos dados secundários relativos à quantidade de agrotóxicos vendidos em Bom Repouso e de embalagens devolvidas pelos agricultores deste município. Os dados de venda foram obtidos junto ao Instituto Mineiro de Agropecuária (IMA) e estavam organizados em uma tabela que continha número e série da nota fiscal, a data da compra, o nome do comprador, o município onde o produto foi comprado, a marca comercial do agrotóxico, o ingrediente ativo do mesmo e a quantidade vendida, dividida em duas colunas, sendo a primeira para as quantidades dos produtos vendidos em unidade de massa e a segunda para os vendidos em unidades de volume. Foram disponibilizados os dados dos anos de 2012 a 2014.

Já os dados de devolução de EVAs foram conseguidos junto à Central de Recolhimento de Embalagens Vazias de Agrotóxicos de Pouso Alegre, onde foram recolhidas as fichas com os dados de devolução por produtor entre os anos de 2010 a 2014. No entanto, foram selecionados para análise os seguintes períodos: 
vendidas em 2012 e devolvidas em 2013; vendidas em 2013 e devolvidas em 2014. O período de um ano foi escolhido devido ao prazo para devolução previsto em lei:

Art.53 - Os usuários de agrotóxicos e afins deverão efetuar a devolução das embalagens vazias, e respectivas tampas, aos estabelecimentos comerciais em que foram adquiridos, observadas as instruções constantes dos rótulos e das bulas, no prazo de até um ano, contado da data de sua compra (BRASIL, 2002).

Nas fichas constam o nome do produtor ou pessoa jurídica responsável pela devolução, o nome da propriedade a que pertencem as EVAs, a data da devolução, os tipos de embalagens devolvidas, suas respectivas quantidades e a medida de volume ou massa de produto que cada embalagem continha. Em alguns casos, no entanto, as quantidades foram registradas como o total de massa de várias EVAs pesadas juntas.

Segundo o IMA, as próprias revendas são responsáveis pelo cadastramento das informações de comercialização, o que favorece a ocorrência de desvios pontuais tais como migração dos dados, unidades de medida variadas e lançamentos equivocados.

Desta maneira, optou-se por corrigir aqueles com quantidades totais muito elevadas ou que possuíam registros nas duas unidades de medida, e transformar todos os dados para medidas de massa $(\mathrm{kg})$. Os registros, em ambos os casos, estavam divididos em produtos vendidos por unidade de massa (formulações em pó ou granulados) e vendidos por unidade de volume (formulações líquidas). Assim, com o objetivo de realizar a análise comparativa, optou-se por encontrar a massa total de embalagens vendidas e de devolvidas por ano. Para tanto, foi necessário fazer o seguinte equacionamento:

Para os registros de produtos vendidos por unidade de volume (formulações líquidas), considerou-se que:

$$
v_{t}=\sum_{1}^{n} v_{n}
$$

em que

$v_{t}=$ volume total de produto vendido no ano (L)

$\boldsymbol{V}_{\boldsymbol{n}}=$ volume de produto contido em cada embalagem (L)

$n=$ número de embalagens 
A massa total de embalagens vazias $\left(m_{t_{v}}\right)$, neste caso, foi obtida pela equação

$$
m_{t_{v}}=\frac{v_{t}}{v_{n}} \bullet m_{L}
$$

sendo $m_{L}=$ massa padrão das embalagens vazias de $1 \mathrm{~L}$ do produto $(0,1 \mathrm{~kg})$.

Considerando os registros de produtos vendidos por unidade de massa (formulações em pó ou granulados), temos que

$$
m_{t}=\sum_{1}^{n} m_{n}
$$

em que

$m_{q}=$ massa total de produto vendido no ano

$m_{n}=$ massa de produto contido em cada embalagem

Há diferentes tipos de embalagens (metálicas, plásticas, de vidro, etc) com diferentes capacidades (garrafas de $1 \mathrm{~L}$, bombonas de $10 \mathrm{~L}$ e $20 \mathrm{~L}$, saquinhos de 5 $\mathrm{kg}$, etc) disponíveis no mercado, sendo inviável tentar relacioná-los com os registros de agrotóxicos comercializados e de EVAs devolvidas.

Os registros do IMA apresentam dados totais por produtor e período, sem discriminar o número de cada tipo e capacidade das embalagens. No caso dos dados da central de Recolhimento de Pouso Alegre, havia registros discriminando as quantidades devolvidas para cada tipo e capacidade de embalagens, mas, em alguns casos, os registros já correspondiam ao total em massa de um conjunto de EVAs recebidos.

Dessa maneira, procurou-se fazer uma padronização dos dados. Para tanto, no caso de produtos com formulação líquida, foram consideradas que todas as embalagens comercializadas ou devolvidas fossem de $1 \mathrm{~L}$ que, quando vazias, pesam 0,1 kg. No caso de produtos comercializados por unidade de massa, foram 
consideradas todas as embalagens como sendo de $1 \mathrm{~kg}$ de produto, que pesa 0,055g cada uma (quando vazia) (informação pessoal) ${ }^{11}$.

Dessa forma, a massa total das embalagens vazias de produtos formulados como pó ou granulados $\left(m_{t_{m}}\right)$ foi obtida pela equação

$$
m_{t_{m}}=\frac{m_{t}}{m_{n}} \bullet m_{K}
$$

em que

$m_{K}=$ massa padrão das embalagens vazias de $1 \mathrm{~kg}$ do produto $(0,000055 \mathrm{~kg})$.

Assim, foram computados os totais de massa de embalagens comercializados no município, para cada uma das unidades de medida, por ano. Para obter a quantidade total de embalagens vazias comercializadas, em unidade de massa, $\left(T_{c}\right)$ em um determinado ano, considerou-se que

$$
T_{c}=m_{t_{v}}+m_{t_{m}}
$$

Os mesmos padrões foram adotados para os dados de devolução. Assim, a massa total das embalagens vazias devolvidas $T_{d}$ foi obtida pela equação

$$
T_{d}=T_{d_{m}}+T_{d_{v}}
$$

em que

$$
T_{d_{m}}=E_{d_{m}} \bullet m_{d_{m}}
$$

sendo

$E_{d_{m}}=$ total de embalagens devolvidas de produtos formulados como pó ou granulados e

$m_{d_{m}}=$ massa padrão das embalagens vazias de $1 \mathrm{~kg}$ do produto $(0,000055 \mathrm{~kg})$.

Enquanto

$$
T_{d_{v}}=E_{d_{v}} \bullet m_{d_{v}}
$$

$E_{d_{v}}=$ total de embalagens devolvidas de produtos formulados como formulação líquida e

\footnotetext{
${ }^{11}$ Contato telefônico com o técnico responsável pela central de devolução de EVAs de Araraquara, SP.
} 
$m_{d_{v}}=$ massa padrão das embalagens vazias de $1 \mathrm{~L}$ do produto $(0,1 \mathrm{~kg})$

A partir desse equacionamento também pôde-se levantar as quantidades totais em massa dos produtos mais vendidos de 2012 a 2014. A partir disso, elaborou-se dois gráficos comparativos entre os sete produtos mais vendidos e a quantidade total devolvida para ambos os períodos. Também foi feita uma tabela contendo os 20 produtos mais vendidos em 2014. A tabela foi elaborada com o objetivo de informar sobre quais os tipos de produtos mais vendidos em Bom Repouso nos períodos selecionados. 


\section{RESULTADOS E DISCUSSÃO}

\subsection{Análise dos dados de comercialização de agrotóxicos e de recolhimento de EVAs em Bom Repouso, MG}

A análise dos dados de cormercialização de agrotóxicos no município de Bom Repouso, nos períodos analisados, revelou elevado número de marcas comerciais de agrotóxicos utilizados no município. Em 2012 foram registrados pelo IMA 201 diferentes produtos comerciais das mais variadas funções (acaricidas, fungicidas, herbicidas, etc). Os registros chegaram a 263 produtos em 2013 e 287, em 2014.

Esse aumento na quantidade de marcas comercializadas pode estar relacionado ao fato de que a produção de morango e batata exige cuidados especiais, pois são cultivos muito suscetíveis a doenças e pragas. O morangueiro, por exemplo, é bastante afetado por fungos, ácaros, formigas e pulgões (SILVA, 2007), sendo que o sistema de cultivo adotado em Bom Repouso (cobertura por túneis plásticos baixos) favorece a proliferação do ácaro rajado (Tetranychus urticae), uma das principais pragas que afetam a cultura (DUARTE, 2013).

No Brasil, o controle deste ácaro se dá principalmente por uso de pesticidas (MORAES; FLHECHTMAN, 2008), e esta é também a realidade em Bom Repouso. No entanto a eficiência desta medida de controle frequentemente não é tão boa, devido a uma série de fatores, como a seleção de ácaros resistentes aos produtos utilizados e a eliminação de inimigos naturais. Assim, além do uso intensivo e até abusivo de agrotóxicos para o controle das pragas e doenças que afetam os cultivos, os produtores têm o hábito de trocar a marca do agrotóxico em decorrência da baixa eficiência dos mesmos com o passar do tempo, pelos motivos citados anteriormente.

Como exemplo, relatos de alguns produtores de Bom Repouso destacam a troca de produtos cujo ingrediente ativo (IA) é a abamectina, visando melhorar o controle do ácaro rajado. Assim, o Vertimec ${ }^{\circledR} 18 \mathrm{EC}$ foi substituído pelo $\mathrm{Kraft}^{\circledR} 36$ $E C$, que tem o dobro da concentração do ingrediente ativo. $\mathrm{Kraft}^{\circledR} 36 \mathrm{EC}$ figura entre os vinte produtos mais vendidos em Bom repouso em 2014, ocupando a décima sétima posição, como pode ser observado no Quadro 5.1. 


\begin{tabular}{|c|c|c|c|c|c|c|c|c|}
\hline \multicolumn{9}{|c|}{20 AGROTÓXICOS MAIS VENDIDOS EM 2014} \\
\hline Marca comercial & Ingrediente ativo & Função & Tipo de formulação & \begin{tabular}{|l|}
$\begin{array}{l}\text { Classificação } \\
\text { toxicológica }\end{array}$ \\
\end{tabular} & $\begin{array}{l}\text { Cor do } \\
\text { rótulo }\end{array}$ & \begin{tabular}{|c|} 
Classificação \\
Ambiental \\
\end{tabular} & $\begin{array}{c}\text { Principais culturas para o qual é } \\
\text { recomendado }\end{array}$ & $\begin{array}{l}\text { Quantidade } \\
\text { do produto }\end{array}$ \\
\hline DITHANE NT & Mancozebe & Fungicida/acaricida & WP - Pó Molhável & 1 & Vermelho & II & $\begin{array}{c}\text { Batata, abóbora, alho, amendoin, arroz, } \\
\text { beringela, beterraba, brócolis, café, cebola, } \\
\text { cenoura, citrus, couve, couve-flor, cravo, } \\
\text { crisântemo, ervilha, feijão, feijão vagem, } \\
\text { figo, fumo, gladíolo, maçã, mamão, manga, } \\
\text { melancia, melão, pêssego, pimentão, } \\
\text { repolho, rosa, tomate, trigo e uva. } \\
\end{array}$ & 11111,41 \\
\hline CIMOX WP HELM & Mancozebe & Fungicida & WP - Pó Molhável & 1 & Vermelho & III & Batata, cebola, tomate e uva. & 4437 \\
\hline BRAVONIL ULTREX & Clorotalonil & Fungicida & $\begin{array}{l}\text { WG - Granulado } \\
\text { Dispersivel }\end{array}$ & 1 & Vermelho & II & $\begin{array}{l}\text { Batata, cebola, cenoura, feijão, maçã, } \\
\text { mamão, melancia, pepino, rosa, tomate e } \\
\text { uva. }\end{array}$ & 4291 \\
\hline FURADAN 50 GR & Carboforano & $\begin{array}{l}\text { Inseticidade/ } \\
\text { Nematicida }\end{array}$ & GR - Granulado & III & Azul & II & $\begin{array}{c}\text { Algodão, amendoin, arroz irrigado, banana, } \\
\text { batata, café, cana de açúcar, cenoura, feijão, } \\
\text { fumo, milho, repolho, tomate e trigo. } \\
\end{array}$ & 4051 \\
\hline MOSPILAN & Acetamiprido & Inseticida & SP - Pó Solúvel & III & Azul & II & $\begin{array}{l}\text { Algodão, batata, feijã, maçã, mamão, } \\
\text { melancia, melão, pinhal manso, tomate e } \\
\text { trigo. }\end{array}$ & 3198,64 \\
\hline CURZATE BR & $\begin{array}{l}\text { Cimoxanil + } \\
\text { Mancozebe }\end{array}$ & Fungicida & WP - Pó Molhável & III & Azul & III & Batata, cebola, tomate e uva. & 2408 \\
\hline ORTHOCIDE 500 & Captana & Fungicida & WP - Pó Molhável & 1 & Vermelho & II & $\begin{array}{c}\text { Abacaxi, algodão, alho, batata, cebola, citrus, } \\
\text { maçã, melancia, melão, milho, pepino, pêra, } \\
\text { pêssego, tomate, trigo e uva. }\end{array}$ & 2374 \\
\hline CABRIO TOP & $\begin{array}{c}\text { Metiram + } \\
\text { Piraclostrobina }\end{array}$ & Fungicida & $\begin{array}{l}\text { WG - Granulado } \\
\text { Dispersivel }\end{array}$ & III & Azul & II & $\begin{array}{c}\text { Abacaxi, alface, alhodão, alho, batata, } \\
\text { beterraba, cebola, cenoura, crisântemo, } \\
\text { feijão, maçã, maracujá, melancia, melão, } \\
\text { pepino, pêssego, pimentão, rosa, tomate e } \\
\text { uva. } \\
\end{array}$ & 1994,6 \\
\hline ORTHENE $750 \mathrm{BR}$ & Acefato & Acaricida/Inseticida & SP - Pó Solúvel & II & Amarelo & II & $\begin{array}{l}\text { Algodão, amendoim, batata, brócolis, citrus, } \\
\text { couve, couve-flor, crisântemo, feijão, melão, } \\
\text { pimentão, repolho, rosa, soja e tomate. }\end{array}$ & 1639,85 \\
\hline
\end{tabular}

Quadro 5.1 - Vinte agrotóxicos mais vendidos em Bom Repouso no ano de 2014 e suas principais características e funções (continua) 
continuação

\begin{tabular}{|c|c|c|c|c|c|c|c|c|}
\hline \multicolumn{9}{|c|}{20 AGROTÓXICOS MAIS VENDIDOS EM 2014} \\
\hline SABRE & Clorpirifós & Inseticida & $\begin{array}{c}\text { EW - Emulsão Óleo } \\
\text { em Água }\end{array}$ & III & Azul & ॥ & $\begin{array}{l}\text { Algodão, batata, café, citrus, milho, soja e } \\
\text { tomate. }\end{array}$ & 9155 \\
\hline GRAMOXONE 200 & $\begin{array}{l}\text { Dicloreto de } \\
\text { Paraquate }\end{array}$ & Herbicida & $\begin{array}{l}\text { SL - Concentrado } \\
\text { Solúvel }\end{array}$ & 1 & Vermelho & ॥ & $\begin{array}{c}\text { Algodão, arroz, banana, batata, café, cana de } \\
\text { açúcar, citrus, couve, feijão, maçã, milho, } \\
\text { oliveira, seringueira, sojae trigo. }\end{array}$ & 7470 \\
\hline $\begin{array}{l}\text { FROWNCIDE } 500 \\
\text { SC }\end{array}$ & Fluazinam & Acaricida/Fungicida & $\begin{array}{l}\text { SC - Suspensão } \\
\text { Concentrada }\end{array}$ & ॥ & Amarelo & 1 & $\begin{array}{l}\text { Algodão, batata, cana - de - açúcar, cebola, } \\
\text { feijão, girassol, maçã, morango, pêssego, } \\
\text { soja e tomate. }\end{array}$ & 4521,2 \\
\hline CURATHANE SC & $\begin{array}{c}\text { Mancozebe + } \\
\text { Cimoxanil }\end{array}$ & Fungicida & $\begin{array}{l}\text { SC - Suspensão } \\
\text { Concentrada }\end{array}$ & III & Azul & III & Batata e tomate. & 3675 \\
\hline $\begin{array}{l}\text { ROUNDUP } \\
\text { ORIGINAL }\end{array}$ & $\begin{array}{l}\text { Glifosato - sal de } \\
\text { Isopropilamina }\end{array}$ & Herbicida & $\begin{array}{l}\text { SL - Concentrado } \\
\text { Solúvel }\end{array}$ & III & Azul & III & $\begin{array}{c}\text { Ameixa, arroz, banana, cacau, café, cana-de- } \\
\text { açúcar, citrus, eucalipto, maçã, milho, } \\
\text { nectarina, pastagens, pêra, pêssego, pinus, } \\
\text { soja, trigo e uva. }\end{array}$ & 3461 \\
\hline PULSOR 240 SC & Tiflusamida & Fungicida & $\begin{array}{c}\text { SC - Suspensão } \\
\text { Concentrada }\end{array}$ & ॥ & Amarelo & III & Batata e café. & 1569 \\
\hline PRIMATOP SC & Atrazina + Simazina & Herbicida & $\begin{array}{l}\text { SC - Suspensão } \\
\text { Concentrada }\end{array}$ & III & Azul & ॥ & Milho. & 1440 \\
\hline KRAFT 36 EC & Abamectina & Acaricida/Inseticida & $\begin{array}{l}\text { EC - Concentrado } \\
\text { Emulsionável }\end{array}$ & 1 & Vermelho & ॥ & $\begin{array}{l}\text { Algodão, batata, café, citrus, crisântemo, } \\
\text { feijão, maçã, mamão, morango, soja e } \\
\text { tomate. }\end{array}$ & 1433,5 \\
\hline SUPERA & Hidróxido de Cobre & Fungicida & $\begin{array}{c}\text { SC - Suspensão } \\
\text { Concentrada }\end{array}$ & III & Azul & III & $\begin{array}{c}\text { Batata, café, citrus, feijão, maçã, pimentão, } \\
\text { tomate e uva. }\end{array}$ & 1216 \\
\hline $\begin{array}{l}\text { ABAMECTIN } \\
\text { NORTOX }\end{array}$ & Abamectina & Acaricida/Inseticida & $\begin{array}{l}\text { EC - Concentrado } \\
\text { Emulsionável }\end{array}$ & III & Azul & III & $\begin{array}{l}\text { Algodão, batata, café, citrus, crisântemo, } \\
\text { feijão, maçã, melancia, morango, pepino, } \\
\text { pimentão, rosa e tomate. }\end{array}$ & 1207 \\
\hline
\end{tabular}

\begin{tabular}{|c|c|c|c|}
\hline \multicolumn{3}{|c|}{ Classificaçao Toocicologica } & $\begin{array}{l}\text { Dassificaça Ambiental } \\
\text { Produto Altamente Perigoso ao Meio }\end{array}$ \\
\hline I - vermelho & $\begin{array}{l}\text { Extremamente } \\
\text { Tóxico }\end{array}$ & 1 & $\begin{array}{l}\text { Produto Altamente Perigoso ao Meio } \\
\text { ambiente }\end{array}$ \\
\hline II - aman & $\begin{array}{l}\text { Altamente } \\
\text { Tóxico }\end{array}$ & & $\begin{array}{l}\text { Produto Muito Perigoso ao Meio } \\
\text { Ambiente }\end{array}$ \\
\hline "II- a a & $\begin{array}{l}\text { Medianamente } \\
\text { Tóxico }\end{array}$ & III & Produto Perigoso ao Meio Ambiente \\
\hline$n-\mathbf{n e}$ & Pouco Tóxico & N & $\begin{array}{l}\text { Produto Pouco Perigoso zo Meio } \\
\text { Ambiente }\end{array}$ \\
\hline
\end{tabular}

Quadro 5.1 - Vinte agrotóxicos mais vendidos em Bom Repouso no ano de 2014 e suas principais características e funções Fonte: Baseado em dados fornecidos pelo IMA (2014) e INPEV (2014) 
Constam entre os 20 produtos mais vendidos em 2014 em Bom Repouso os alguns ingredientes ativos registrados pelo IBAMA como os mais vendidos no Brasil, de 2000 a 2012, dentre os quais se destacam o glifosato, com 186.483 toneladas vendidas no país em 2012, correspondendo a 39,03\% do total de IAs comercializado (IBAMA, 2013). A ele, ainda segundo o mesmo relatório do Ibama, seguiram-se naquele ano: 2,4-D, atrazina, acefato, diurom, carbendazim, mancozebe, metomil, clorpirifós, imidacloprido e dicloreto de paraquate. Observa-se que cinco destes ingredientes ativos (atrazina, acefato, mancozeb, clorpirifós e dicloreto de paraquate) também se destacam entre os 20 produtos mais vendidos em Bom Repouso em 2014.

Dithane NT, cujo ingrediente ativo é o mancozeb, foi o agrotóxico mais vendido no município em 2014. Em apenas um ano foram vendidos $11111,41 \mathrm{~kg}$ desse produto, mesmo este sendo um fungicida classificado como extremamente tóxico para saúde humana e muito perigoso para o meio ambiente. Também destaca-se o mancozebe, pois é um dos fungicidas ditiocarbamatos mais utilizados em propriedades rurais no Brasil. Essa ampla utilização de ditiocarbamatos no mercado nacional deve-se ao fato do produto ter baixo custo, ser de fácil manuseio e apresentar amplo espectro e compatibilidade com a maioria dos inseticidas e adjuvantes. No entanto, o principal produto de degradação dos fungicidas ditiocarbamatos é a etilenotiouréia (ETU), considerada substância de ação cancerígena e mutagênica (GUIMARÃES, 2015).

O glifosato, ingrediente ativo do herbicida Roundup, também foi um dos mais vendidos em Bom Repouso em 2014, ocupando a nona posição no Quadro 4.1, apresentado anteriormente. Segundo a Agência Internacional de Pesquisas do Câncer (larc, na sigla em inglês), órgão da Organização Mundial da Saúde (OMS), o Roundup é o agrotóxico mais vendido no mundo mesmo sendo classificado como "provavelmente" ou "possivelmente" carcinogênico (CARNEIRO et al., 2015). No entanto, as sugestões da OMS têm autoridade moral, mas não legal e por isso podem ou não ser adotadas pelos seus países-membros (GUIMARÃES, 2015).

Intoxicações envolvendo agrotóxicos no Brasil foram analisadas por Benatto (2002) $\square$ com base em dados do Sistema Nacional de Agravos Notificados (Sinan). Segundo esse autor, foi registrado no período de 1996 a 2000 um total de 5.654 casos suspeitos de intoxicação, com 2.931 casos confirmados $(51,43 \%)$. O número de óbitos registrado foi de 227 , correspondendo a uma letalidade de $7,73 \%$ no período. As intoxicações se concentraram em indivíduos do sexo masculino entre 15 e 49 anos, sendo confirmadas pelo 
critério clínico-epidemiológico em $60 \%$ dos casos; $61,74 \%$ dos casos de intoxicação receberam atendimento hospitalar; $29,46 \%$ atendimento ambulatorial; $7,03 \%$ atendimento domiciliar e $1,77 \%$ dos casos não receberam nenhum atendimento. Os acidentes de trabalho representaram 53,5\% das circunstâncias de intoxicação, seguidos pelas tentativas de suicídio $(28,2 \%)$ e por intoxicações acidentais $(12,9 \%)$. Dentre os 128 princípios ativos envolvidos nas intoxicações o glifosato, o paraquat e o metamidofós foram os agentes tóxicos mais incriminados, correspondendo a $26,2 \%$ do total. Os registros desses três agrotóxicos estão sendo reavaliados pela Anvisa, e o metamidofós passou a ser proibido no Brasil no ano de 2011 (CARNEIRO et al., 2015).

Dessa forma, pôde-se avaliar que a tabulação e análise dos dados secundários de vendas e devolução de agrotóxicos são essenciais para a assimilação dos possíveis cenários de contaminação existente no município estudado. Ao conseguir destacar os produtos mais utilizados no município, pode-se associar essa informação com outras ligadas a problemas ambientais e de saúde pública, como aumento no caso de intoxicações.

Com o intuito específico de entender a efetividade da logística reversa de EVAs no município, foram feitos os comparativos entre os totais de embalagens vendidas no município em 2012 e de devolvidas em 2013, e de vendidas em 2013 e devolvidas em 2014. As Tabelas 5.1 e 5.2 apresentam os resultados do processo de equacionamento para obtenção da quantidade total de massa de embalagens vendidas nos anos de 2012 e 2013, respectivamente. Já a Tabela 5.3 apresenta os resultados para obtenção da massa total de embalagens devolvidas nos anos 2013 e 2014.

Tabela 5.1 - Resultados do processo de equacionamento para obtenção da quantidade total de massa de embalagens vendidas em 2012

\begin{tabular}{|c|c|c|c|c|}
\hline \multicolumn{4}{|c|}{ VENDIDAS 2012} & \multirow{2}{*}{$\begin{array}{c}\text { Massa Total Do } \\
\text { Ano }(\mathrm{Kg})\end{array}$} \\
\hline $\begin{array}{l}\text { Massa total de } \\
\text { produto }(\mathrm{kg})\end{array}$ & $\begin{array}{c}\text { Massa de produto } \\
\text { dentro da } \\
\text { embalagem }(\mathrm{kg})\end{array}$ & $\begin{array}{c}\text { Número de } \\
\text { embalagens } \\
\text { (unidades) }\end{array}$ & $\begin{array}{c}\text { Massa da } \\
\text { embalagem vazia } \\
(\mathrm{kg})\end{array}$ & \\
\hline 45581,67 & 1 & 45582 & 0,000055 & 2,51 \\
\hline $\begin{array}{l}\text { Volume total de } \\
\text { produto }(L)\end{array}$ & $\begin{array}{c}\text { Volume de produto } \\
\text { dentro da } \\
\text { embalagem }(L)\end{array}$ & & & \\
\hline \multirow[t]{2}{*}{30632,11} & 1 & 30632 & 0,1 & 3063,21 \\
\hline & & & & 3065,72 \\
\hline
\end{tabular}


Tabela 5.2 - Resultados do processo de equacionamento para obtenção da quantidade total de massa de embalagens vendidas em 2013

\begin{tabular}{|c|c|c|c|c|}
\hline \multicolumn{4}{|c|}{ VENDIDAS 2013} & \multirow[t]{2}{*}{$\begin{array}{c}\text { Massa Total Do } \\
\text { Ano }(\mathrm{Kg})\end{array}$} \\
\hline $\begin{array}{l}\text { Massa total de } \\
\text { produto }(\mathrm{kg})\end{array}$ & $\begin{array}{c}\text { Massa de produto } \\
\text { dentro da } \\
\text { embalagem }(\mathrm{kg})\end{array}$ & $\begin{array}{l}\text { Número de } \\
\text { embalagens } \\
\text { (unidades) }\end{array}$ & $\begin{array}{c}\text { Massa da } \\
\text { embalagem vazia } \\
(\mathrm{kg})\end{array}$ & \\
\hline 75775,31 & 1 & 75775 & 0,000055 & 4,17 \\
\hline $\begin{array}{l}\text { Volume total de } \\
\text { produto }(L)\end{array}$ & $\begin{array}{c}\text { Volume de produto } \\
\text { dentro da } \\
\text { embalagem }(L)\end{array}$ & & & \\
\hline \multirow[t]{2}{*}{87396,67} & 1 & 87396 & 0,1 & 8739,67 \\
\hline & & & & 8743,84 \\
\hline
\end{tabular}

Tabela 5.3 - Resultados do processo de equacionamento para obtenção da quantidade total de massa de embalagens devolvidas em 2013 e 2014

DEVOLVIDAS 2013

\begin{tabular}{|c|c|c|c|c|}
\hline & $\begin{array}{l}\text { Número de } \\
\text { embalagens } \\
\text { (unidades) }\end{array}$ & $\begin{array}{c}\text { Massa da } \\
\text { embalagem } \\
\text { vazia }(\mathrm{kg})\end{array}$ & $\begin{array}{c}\text { Total em massa de EVAs } \\
\text { recebidas e pesadas } \\
\text { conjuntamente }\end{array}$ & $\begin{array}{c}\text { Massa } \\
\text { Total Do } \\
\text { Ano }(\mathrm{Kg})\end{array}$ \\
\hline $\begin{array}{c}\text { Embalagens vazias } \\
\text { de formulações } \\
\text { secas }\end{array}$ & 1230 & 0,000055 & $\longrightarrow$ & 0,07 \\
\hline \multirow[t]{3}{*}{$\begin{array}{c}\text { Embalagens vazias } \\
\text { de formulações } \\
\text { líquidas }\end{array}$} & 522 & 0,1 & 50 & 102,2 \\
\hline & & & & 102,3 \\
\hline & \multicolumn{3}{|c|}{ DEVOLVIDAS 2014} & \\
\hline $\begin{array}{c}\text { Embalagens vazias } \\
\text { de formulações } \\
\text { secas }\end{array}$ & 466 & 0,000055 & 181 & 181,03 \\
\hline \multirow[t]{2}{*}{$\begin{array}{c}\text { Embalagens vazias } \\
\text { de formulações } \\
\text { líquidas }\end{array}$} & 244 & 0,1 & 125 & 149,4 \\
\hline & & & & 330,43 \\
\hline
\end{tabular}

Nota-se que, no período 2012-2013, a quantidade de embalagens vendidas foi cerca de 30 vezes maior que a de embalagens devolvidas, e para o período entre 2013-2014 a mesma relação foi da ordem de 26 vezes (Figura 5.1). Além disso, a massa total de embalagens devolvidas corresponde a apenas 3,3\% da massa de vendidas no período 2012-2013, e 3,8\% para 2013-2014. Ou seja, aproximadamente 
96\% das embalagens comercializadas em ambos os períodos não foram devolvidas à central de Pouso Alegre.

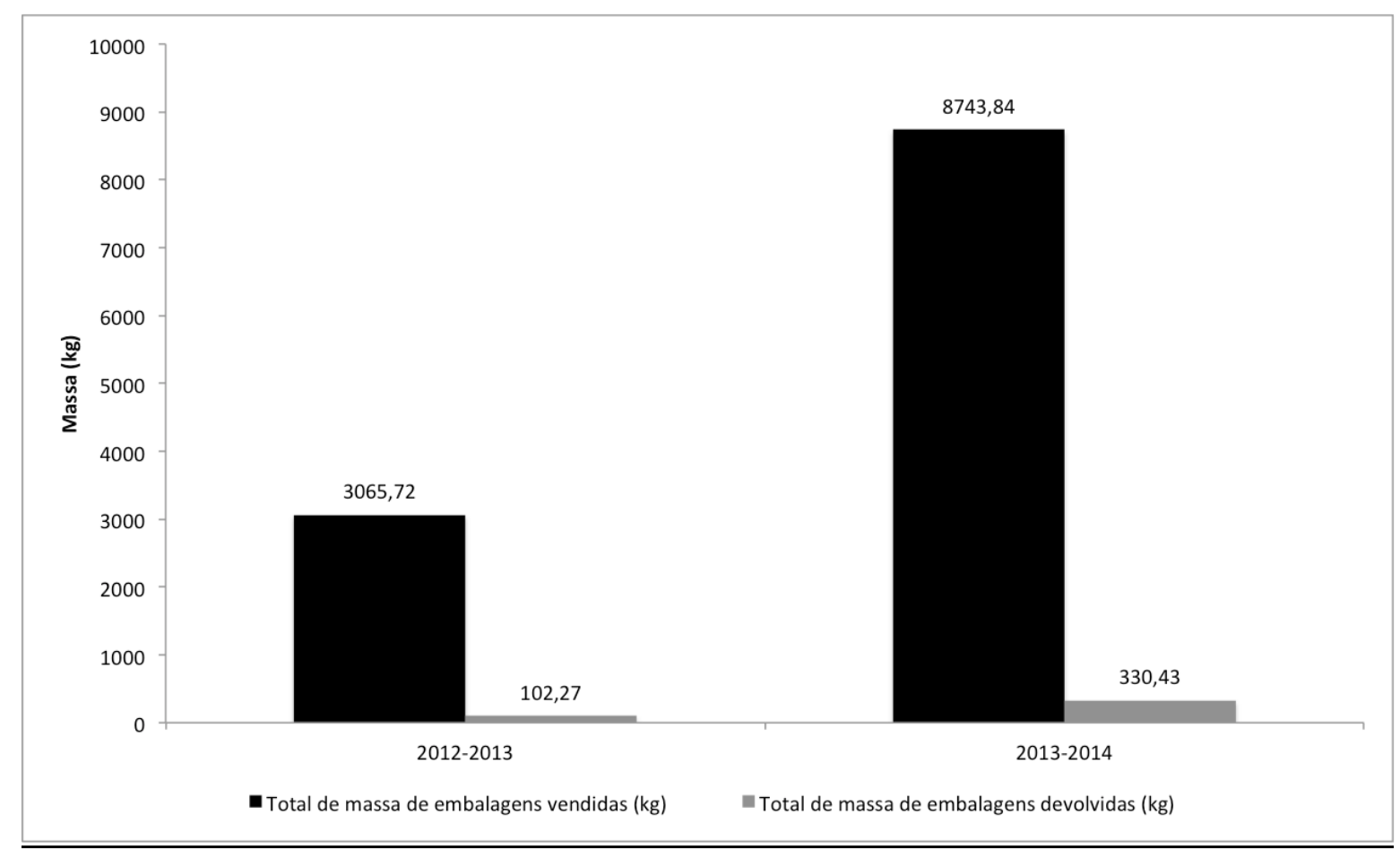

Figura 5.1 - Comparativo entre total de embalagens de agrotóxicos vendidas em 2012 e 2013, no município de Bom Repouso, MG, e total de embalagens vazias devolvidas por produtores do município à Central de Recolhimento de Pouso Alegre, em 2013 e 2014

Fonte: Baseado em dados fornecidos pelo IMA (2014) e INPEV (2014)

Outro dado relevante é a variação das quantidades vendidas e devolvidas em função do tempo como mostrado na Figura 5.2.

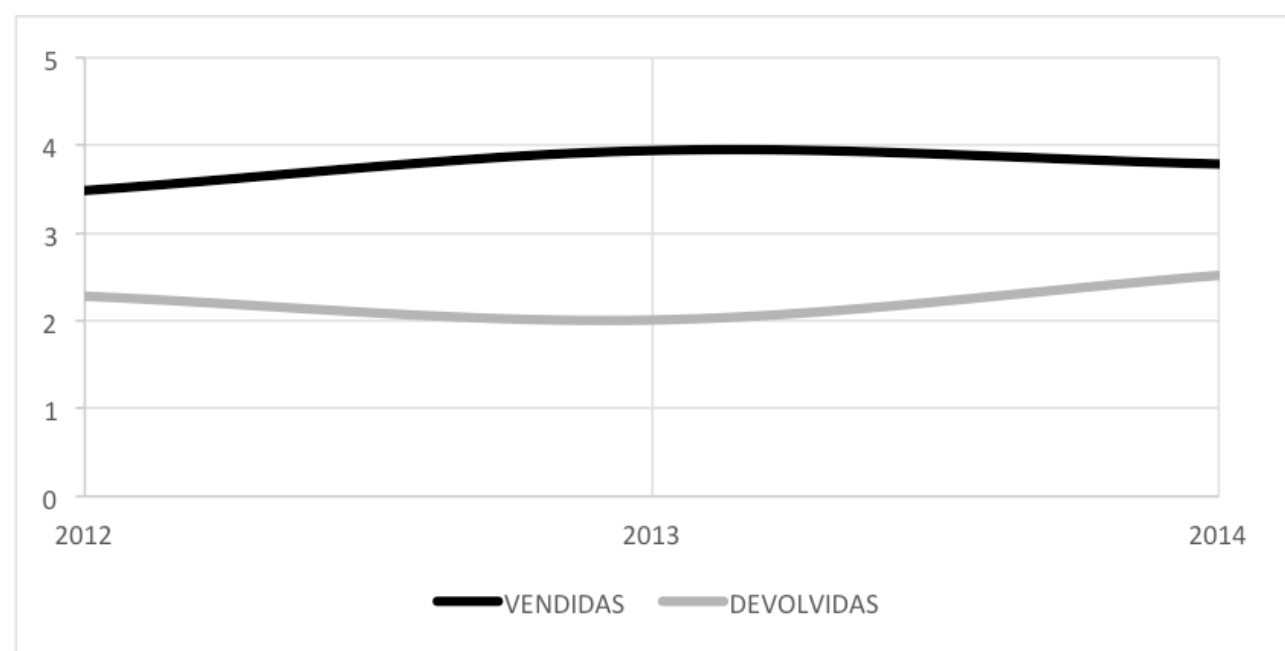

Figura 5.2 - Variação das quantidades de EVAs vendidas e devolvidas em função do tempo Fonte: Baseado em dados fornecidos pelo IMA (2014) e INPEV (2014) 
É nítida a associação entre a quantidade vendida e devolvida quando consideramos a exigência de entrega das EVAs no máximo após 1 ano da compra dos agrotóxicos. Por exemplo, é possível verificar na Figura 5.2 que o aumento das vendas em 2013 correspondem a um consequente aumento no número de devoluções no ano seguinte.

Considerando-se os sete produtos mais vendidos nos períodos analisados, verificou-se que apenas para três deles o total de massa de embalagens comercializadas no município foi menor que o total em massa de embalagens devolvidas pelos produtores à Central de Recolhimento de Pouso Alegre (Figuras 5.3 e 5.4).

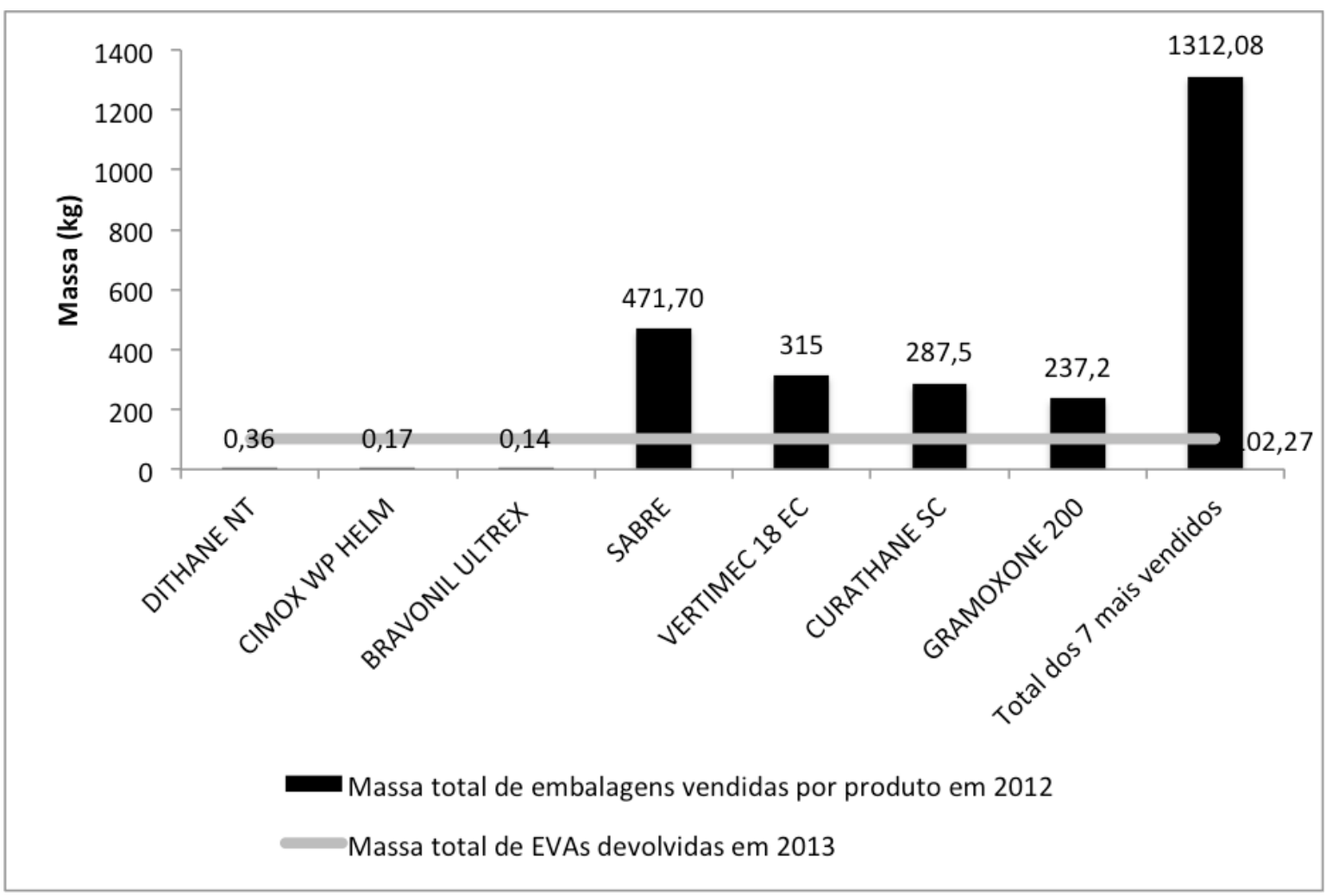

Figura 5.3 - Comparativo entre a massa total de embalagens dos 7 produtos mais comercializados em Bom Repouso, MG, em 2012 e a massa total de EVAs devolvidas à Central de Recolhimento de Pouso Alegre, em 2013

Fonte: Baseado em dados fornecidos pelo IMA (2014) e INPEV (2014) 


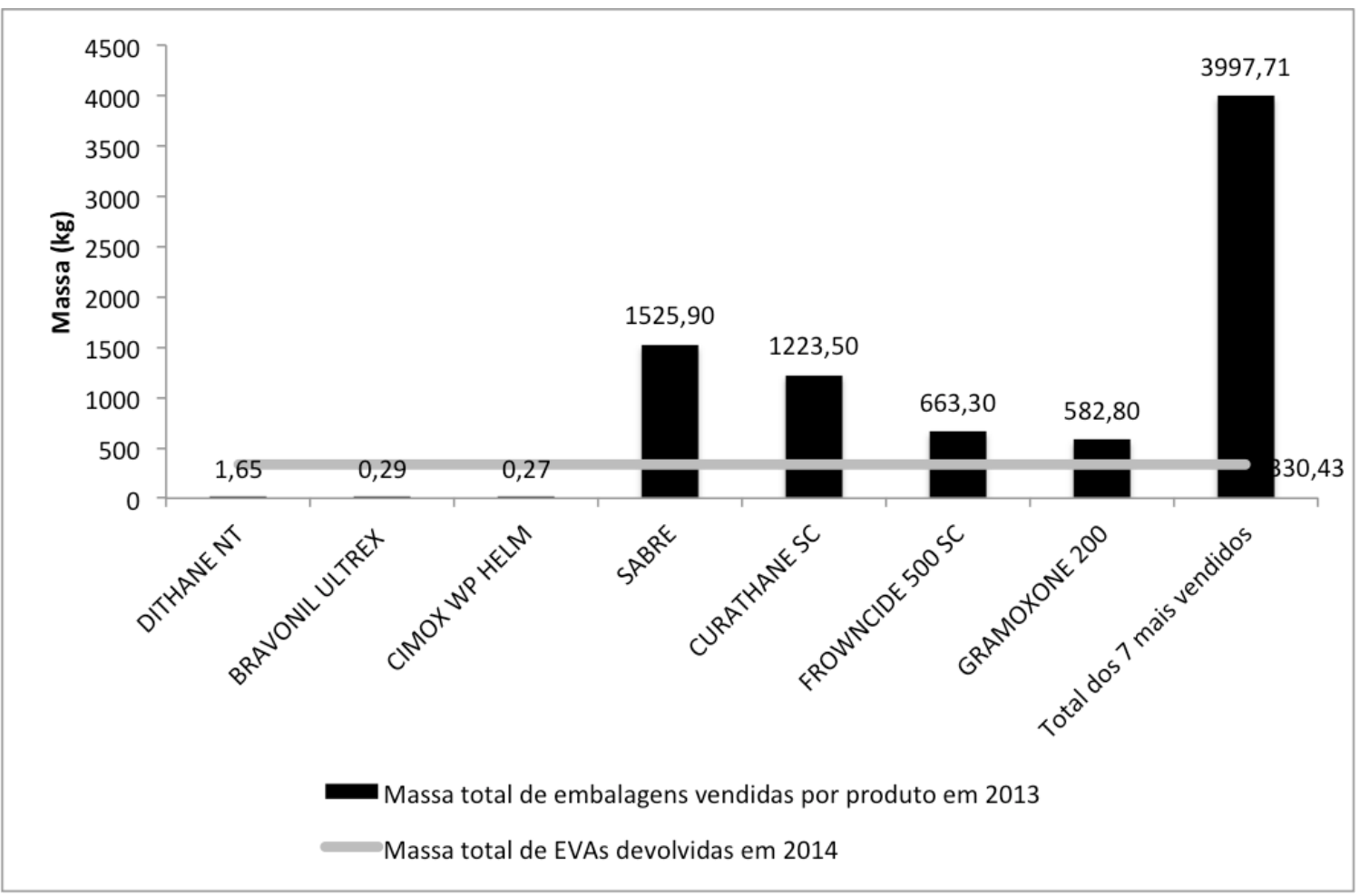

Figura 5.4 - Comparativo entre a massa total de embalagens dos 7 produtos mais comercializados em Bom Repouso, MG, em 2013 e a massa total de EVAs devolvidas à Central de Recolhimento de Pouso Alegre, em 2014

Fonte: Baseado em dados fornecidos pelo IMA (2014) e INPEV (2014)

Também é possível verificar que a soma das massas totais dos 7 produtos já é muito maior que a massa total de EVAs devolvidas, em ambos os períodos (Figuras 5.3 e 5.4).

O panorama configurado por esses dados apresenta uma realidade preocupante. Esta pode ser decorrente de vários fatores, mas, de acordo com estudos anteriores (COMETTI; ALVES, 2010; VEIGA, 2009) e depoimentos dos atores envolvidos no processo, em Bom Repouso, o principal motivo da não devolução é a dificuldade financeira e prática de se armazenar as EVAs nas propriedades (o correto seria ter uma "baia" específica para armazenar as EVAs até que se tenha uma quantidade relevante) e transportá-las até a central. No caso do município de Bom Repouso, este fato se confirma, uma vez que os produtores tem que percorrer em média $60 \mathrm{Km}$ para devolver as EVAs na central mais próxima.

Como afirmam vários autores, (FLEISCHMANN, 2001; FERRER; WHYBARK, 2000; KRUMWIEDE; SHEU, 2002; TIBBEN- LEMBKE; ROGERS, 2002), o transporte dos produtos usados é o maior desafio da logística reversa, principalmente pela possibilidade de se ter que transportar pequenas quantidades e 
pela variabilidade dos tipos de produtos, fatores que aumentam os custos de transporte (VEIGA, 2013). Portanto, esta é uma questão que deve ser prioritariamente analisada e solucionada.

\subsection{Entrevistas}

A respeito da responsabilidade compartilhada e as dificuldades para arcar com a mesma, houve diferentes abordagens nas falas dos entrevistados. Segundo o representante do Sindicato dos Trabalhadores Rurais de Bom Repouso, deve haver mais fiscalizações e cobrança por parte dos órgãos responsáveis. Ele destacou a importância do IMA como órgão fiscalizador e afirmou acreditar que o medo das multas é o fator que leva um produtor a devolver as EVAs Corretamente. Considera, ainda, serem as multas a forma mais eficaz de conscientização. Com relação ao Poder público, acredita que o mesmo tem que ajudar financeiramente, pois o lucro da agricultura já é pequeno. Comentou que há falta de compromisso dos produtores e dos revendedores com relação à destinação adequada das EVAs:

"Falta compromisso também. Às vezes é até preguiça. Ele tem condição de trazer, mas ele deixa lá no canto e não traz.

Outra coisa, é a loja. Eles falam bonitinho, vem e promove uma palestra, mas talvez na hora dele sair a campo pra recolher aquilo ali, ele cria obstáculo".

Já o representante da central de recolhimento de EVAs de Pouso Alegre, destacou o prejuízo que a central e o INPEV assumem, pelo fato de os produtores não cumprirem com a obrigação de realizar a tríplice lavagem ou lavagem sobre pressão e furar as embalagens vazias.

Quando os produtores não realizam esses procedimentos, as embalagens são consideradas resíduos perigosos por conterem restos de agrotóxicos. Sendo assim, não podem ser encaminhadas para a reciclagem e precisam ser incineradas, processo muito mais custoso.

O representante da Central também considera que a fiscalização por parte do IMA deveria ser mais efetiva, e que muitas vezes o produtor é omisso e relapso com 
relação ao cumprimento da lei e participação no processo de destinação correta da EVAs.

Já o representante da prefeitura de Bom Repouso, responsável pelos assuntos de Meio Ambiente do município, ressaltou que existe uma preocupação e uma disposição em cumprir a legislação por parte do produtor, mas também concorda que muitas vezes falta o compromisso dos mesmos.

Todos os revendedores entrevistados afirmam que a maior dificuldade para as revendas aceitarem as EVAs é a necessidade de se ter um local adequado, seguro, para armazená-las até que as mesmas possam ser levadas para a central de recolhimento.

Esses comentaram também sobre o problema dos vendedores de agrotóxicos que agem clandestinamente e que, portanto, eles não tinham condições de assumir a sua parte na devolução correta de embalagens que não foram comercializadas por suas revendas.

Destacaram ainda a questão econômica como empecilho para que cumpram sua parte na responsabilidade compartilhada, já que os comerciantes, ao se credenciarem a uma unidade de recebimento de EVAs, pagam uma taxa fixa mensal, além de outra taxa que varia conforme a quantidade de embalagens destinadas.

Um fato curioso foi o relato de um dos revendedores, que considera que a orientação aos produtores sobre suas responsabilidades e exigências do processo de logística reversa deveria ser dada apenas pelos órgãos fiscalizadores e pelo inpEV. Esta fala demonstrou a preocupação dos revendedores de perder sua clientela se tiverem que passar também a orientar, lembrar e cobrar dos produtores o cumprimento de suas responsabilidades na devolução das EVAs.

Quando questionados sobre as possíveis soluções para evitar o descarte inadequado de EVAs no município, dos sete revendedores entrevistados, três apontaram a criação de um ponto de coleta no município e outros dois, a coleta itinerante. Dos dois restantes, um considerava ambas as soluções como adequadas e bem vindas, e o outro não concordou com nenhuma das opções.

Já o representante do Sindicato dos Trabalhadores Rurais de Bom Repouso concorda com a implantação da coleta itinerante no município, afirmando ainda que o Sindicato poderia contribuir com a fazendo a divulgação de informações sobre a mesma. Acredita que esta é a melhor opção, pois não confia que a implantação de 
um posto de recebimento no município funcionaria devido à falta de estrutura, auxílio e verba para manutenção:

"Quem vai coordenar isso? Quem vai receber?".

Aconselhou, ainda, que as lideranças das comunidades sejam procuradas, para auxiliar no agendamento das coletas. Sobre este tema, o representante da central de recebimento afirmou que o inpEV estava avaliando a possibilidade de expandir a coleta itinerante e que a mesma poderia ser organizada em Bom Repouso, sem dificuldades.

A coleta itinerante pode contribuir para que o produtor se sinta menos exigido e prejudicado financeiramente, já que não precisará ter custos tão altos com transporte e perda de horas de trabalho para levar as EVAs até a central. Porém, pode-se imaginar que essa opção seja mais onerosa para o inpEV. Mas, considerando que produtores mais engajados também poderiam contribuir para a diminuição do número de embalagens sem tríplice lavagem ou lavagem sobpressão, com consequente menor necessidade de destinação de embalagens para a incineração, o resultado seria uma diminuição do custo com esse tratamento tão caro de resíduos.

Já o representante da prefeitura apresentou uma opinião contrária à coleta itinerante, apoiando a construção de um ponto de coleta em Bom Repouso. Ele justificou sua preferência por considerar que isto facilitaria para os produtores em termos logísticos e financeiros, uma vez que entende que o produtor é o elo mais frágil da cadeia e por isso deve ser preservado e orientado.

Afirmou, ainda, que a prefeitura disponibilizaria recursos para a construção do ponto de coleta. No entanto, destacou que essa alternativa já tinha sido pensada no passado e não deu certo devido à falta de envolvimento dos revendedores, que não queriam contribuir financeiramente e nem assumir o gerenciamento do ponto.

Como afirma Cometti e Alves (2010), é imprescindível que a responsabilidade pós-consumo seja adotada de forma ampla e irrestrita e que se exija de todos o seu cumprimento. Sendo assim, seria mais pertinente a busca por uma solução que seja economica, ténica e legalmente viável para todos os envolvidos. Nesse caso, a coleta itinerante parece ser a mais indicada, uma vez que seja bem planejada e constante. 
Em seu relatório de sustentabilidade 2014, o inpEV comenta a implementação, no mesmo ano, do Sistema de logística (SisLog). Este foi construído em parceria com as empresas associadas ao inpEV e permite avaliar e otimizar custos de transporte e frete. Segundo o inpEV (2015), o SisLog foi um avanço importante e permitiu um melhor gerenciamento do valor do frete praticado pelo inpEV, com economia para a indústria.

\begin{abstract}
Na operação, os principais destaques foram a sistematização e a ampliação do recebimento itinerante, para levar os benefícios da logística reversa a pequenos agricultores de áreas que não contam com uma cadeia de distribuição consolidada. Também mantivemos nosso foco em segurança: intensificamos nossas ações sobre o tema e demos continuidade a capacitação de gestores das centrais de recebimento (INPEV, 2015).
\end{abstract}

Além disso, foi adotado em 35 centrais em 2014 o Agendamento de Devolução de Embalagens Vazias (adEV). Este oferece mais uma opção de devolução de EVAS ao agricultor, que pode programar, do seu computador, celular ou tablet, suas entregas a longo prazo, possibilitando prever a quantidade de EVAs nas centrais, o que garante uma operação logística mais eficiente e melhor aproveitamento da mão de obra. No entanto, há que se considerar até que ponto essas tecnologias estão disponíveis para produtores de municípios como Bom Repouso, sendo necessário um diagnóstico da possibilidade de adesão dos produtores a essas ferramentas.

Com relação ao conhecimento sobre as consequências negativas do uso de agrotóxicos e do descarte inadequado de EVAs, o presidente do Sindicato dos Trabalhadores Rurais de Bom Repouso admitiu que vários conhecidos já tiveram problemas relacionados ao uso de agrotóxicos (câncer, intoxicações, problemas renais, leucemia) e parentes que morreram devido a essas doenças.

Afirmou, ainda, que há muitos casos de câncer no município relacionados ao uso intensivo de agrotóxicos, além de ser onde mais se distribui antidepressivos na região. A depressão é um dos graves problemas relacionados ao uso intensivo de agrotóxicos. O entrevistado comentou também que ainda existem intoxicações, mas que as mesmas são antigas, ou seja, crônicas. Considera que $80 \%$ dos produtores do município usa equipamentos de proteção individual (EPIs) para aplicação de agrotóxicos.

Já o representante da central do inpEV em Pouso Alegre disse que os envolvidos sabem dos riscos relacionados ao descarte inadequado das EVAs, pois 
há muitas palestras e programas educativos disponíveis para os produtores e revendedores.

Em contraponto, o representante da prefeitura alegou que ainda assim, falta muita informação sobre os riscos associados ao uso dos agrotóxicos. Acredita que, por questões culturais, muito da informação é ignorada, sendo priorizada a necessidade de produzir rápido e com custo baixo. O uso dos EPIs também é ignorado e subestimado. Dessa maneira, ele disse acreditar que o uso de agrotóxicos no município está banalizado, e que como consequência disso há uma alta incidência de câncer e depressão na cidade, comprovadamente ligadas ao contato com esses produtos.

Dos sete revendedores entrevistados, quatro disseram acreditar que os produtores têm noção dos riscos associados ao descarte inadequado de EVAs. O restante acredita que não, que ainda há falta de informações importantes para os produtores. Alguns também afirmaram que o uso excessivo de agrotóxicos no município é cultural.

\subsection{Levantamento Documental}

No que diz respeito ao levantamento documental, em visita à prefeitura municipal de Bom Repouso, foram solicitados documentos em que pudessem constar qualquer tipo de legislação, orientação ou determinação sobre a gestão de EVAs no município. Os documentos disponíveis para consulta foram:

- Termo de referência para elaboração do relatório técnico para o atendimento do termo de ajustamento de conduta ambiental - TAC: visa orientar a elaboração do relatório técnico para o atendimento do termo de ajustamento de conduta ambiental - TAC firmado entre o município, o conselho estadual de política ambiental (COPAM) e a fundação estadual do meio ambiente FEAM. Esse documento é relativo ao funcionamento do Vazadouro erroneamente denominado aterro sanitário presente no município, onde são depositados os resíduos sólidos de todos os tipos gerados pela população de Bom Repouso.

- Lei no 123/97, de 20 de outubro de 1997: proíbe o uso de substâncias tóxicas nas proximidades de escolas e locais de recreação pública do município e dá outras providências. 
- Lei no 002/93, de 5 de março de 1993: proíbe a utilização de produtos agrotóxicos na área circundada e dá outras providências.

- Código de posturas do município de Bom Repouso: contém as medidas de polícia administrativa a cargo do município em matéria de higiene, ordem pública e funcionamento dos estabelecimentos comerciais e industriais, estatuindo as necessárias relações entre o poder público local e os munícipes.

- Lei orgânica do município de Bom Repouso, Minas Gerais, 1990: é a lei maior do município, através da qual o mesmo se organiza. Está para o município como a Constituição Federal está para a União. Podem ser tidas como Constituições Municipais.

Em nenhum desses documentos havia legislações ou determinações específicas sobre a gestão e o gerenciamento de EVAs no município. Essa falta de instrumentos legais confirma a ausência de gestão no município. Ou seja, se não existe gestão, consequentemente, não há metas e não se sabe a eficiência do gerenciamento instalado. Nesse caso, o gerenciamento é representado pela logística reversa de EVAs instituído e coordenado pelo inpEV.

Segundo Córdoba (2014), pode existir gerenciamento sem existir gestão e vice-versa. A situação "gerenciamento sem gestão" normalmente ocorre em municípios de pequeno porte que não possuem equipes de gestores, e, de maneira geral, não têm verba para contratação de profissionais para traçar seus planos de gestão e incentivar a efetividade de instrumentos legais já existentes e a criação de novos.

Esse é o caso do município de Bom Repouso, cuja realidade conduz a soluções pouco eficientes justamente por não existir uma base estratégica que envolva a avaliação do contexto local, considerando suas respectivas necessidades para a seleção e combinação das atividades mais adequadas para essas condições.

A inexistência do Plano Municipal de Gestão Integrada de Resíduos Sólidos (PMGIRS), considerado um bom exemplo de modelo de gestão (CÓRDOBA, 2014), mostra o atraso do município de Bom Repouso. Em entrevista, o responsável pelos assuntos de meio ambiente da prefeitura e presidente do Conselho Municipal de Meio Ambiente do município, afirmou que o município estava buscando profissionais para a elaboração do plano e apontou a importância dessa ferramenta de gestão: 
"Eu enxergo de supra importância para o município as questões, tanto as questões ambiental, quanto de resíduo sólido. Sendo uma cidade agrícola, quase $80 \%$ de agricultura, tanto agricultura familiar, acho de suma importância ter esse apoio, tanto na parte ambiental, como na parte também da saúde da população que faz uso desses agrotóxicos. (...) Eu acho que esse plano aqui para a cidade seria de supra importância, primeiramente, porque nós ainda temos lixão e sabemos que o lixão, esse descarte muitas vezes da embalagem é feito diretamente ao lixão, então esse ponto de coleta seria essencial para a questão do lixão pois essas embalagens que ficam lá tem muita gente que cata lixo, que trabalha no lixão de forma desapropriada".

No entanto, o plano ainda não havia sido elaborado e sequer havia previsão de quando isso seria feito até o momento em que esta pesquisa foi encerrada . 


\section{CONCLUSÕES}

A realização desta pesquisa permitiu concluir que:

- A realidade da logística reversa de EVAs em Bom Repouso está ainda bastante aquém das estatísticas nacionais apresentadas pelo inpEV, que colocam o país como destaque na destinação correta desses resíduos;

- A existência de instrumentos legais que institucionalizem a logística reversa de EVAs em Bom Repouso, bem como em municípios de mesmo porte e características, é de suma importancia para garantir a seriedade do processo, bem como para pautar as medidas punitivas a nível do governo do município para aqueles que não cumprirem com sua responsabilidade enquanto elo da cadeia;

- É imprescindível que os municípios elaborem seus PMGIRS e outros instrumentos legais que instituicionalizem a gestão de EVAs em seus territórios. Não há como controlar, criar metas e obter uma fiscalização eficaz sem a existência dessas ferramentas;

- A gestão dos dados relativos à situação da venda de agrotóxicos e devolução das embalagens vazias dos mesmos precisa ser criteriosamente revista e aperfeiçoada, pois esses dados são essenciais para comprovar e compreender o panorama das EVAs num determinado município ou região;

- Para favorecer esta análise comparativa, os registros deveriam ser feitos levando-se em conta a massa das embalagens, como demostrado no equacionamento elaborado neste estudo. Além disso, deveria ser criado um banco de dados conjunto entre o inpEV e os orgãos fiscalizadores, o que poderia, por exemplo, auxiliar na identificação de onde a fiscalização deve ser aplicada com mais rigor, facilitando o planejamento das mesmas. Esse processo deveria ser responsabilidade das empresas fabricantes de agrotóxicos, bem como do inpEV, afim de garantir a transparência dos dados e informações aos orgãos fiscalizadores e à sociedade; 
- O investimento em coletas itinerantes é, no momento, uma das melhores opção para os produtores rurais de Bom Repouso. A construção de um ponto de coleta no município não parece viável, em função dos custos elevados e de atores envolvidos no sistema ainda se considerarem sem condições de assumir a responsabilidde pela gestão do mesmo;

- Da mesma forma, a coleta itinerante agendada mostra-se como opção adequada ao município de Bom Repouso e outros semelhantes, por permitir que produtores se sintam menos exigidos e prejudicados finaceiramente, não precisando arcar com altos custos relacionados ao transporte e com a perda de horas de trabalho para transportar as EVAs até a central mais próxima. Embora em um primeiro momento esta opção possa ser considerada mais onerosa para o inpEV, deve-se ter em conta que produtores mais engajados também contribuem para a diminuição do número de EVAs sem tríplice lavagem ou lavagem sob-pressão. Como resultado, menos embalagens necessitariam ser destinadas à incineração e, em consequência, os custos para o inpEV seriam reduzidos.

- Uma vez que o inpEV disponibilize caminhões preparados para transportar resíduos perigosos, a coleta itinerante também poderá reduzir a poluição difusa por restos de agrotóxicos que caem das embalagens, quando transportadas em automóveis normais, pelos produtores.

- A divulgação das coletas itinerantes via rádio, contando com a ação do Sindicato dos Trabalhadores Rurais de Bom Repouso, sugerida pelo presidente do sindicato, é a forma mais eficaz de informar o produtor rural, por ser este o meio de comunicação mais utilizado pelos mesmos.

- Seja para Bom Repouso ou qualquer outro município de mesmo porte e características, a gestão das EVAs só será realmente eficiente quando a mesma for transparente e entendida como um compromisso extremamente sério por todos os envolvidos no ciclo da logística reversa desses resíduos. 


\section{CONSIDERAÇÕES FINAIS E RECOMENDAÇÕES}

A criação pelo inpEV de um sistema de recolhimento e de programas de conscientização sobre a importância da devolução das EVAs para evitar a poluição ambiental e os riscos à saúde humana decorrentes da contaminação por agrotóxicos foi um grande avanço para a gestão destes resíduos no país. No entanto, a presente pesquisa confirmou, com um estudo de caso, que a logística reversa dessas embalagens não obtém em municípios de pequeno porte o mesmo desempenho alcançado nacionalmente como apontado pelo instituto.

Considera-se que a realidade política, estrutural, cultural e financeira de Bom Repouso reflete uma situação comum a vários outros municípios brasileiros. Assim, da mesma forma que para o caso estudado, é possível que haja muitos outros municípios que não possuem uma gestão eficiente de EVAs em decorrência da falta de planejamento estratégico, de instrumentos legais, de parcerias duradouras e multilaterais entre os envolvidos, e de participação popular.

A gestão do recolhimento de EVAs nesses locais está pautada na logística reversa implementada pelo inpEV e apoiada pelos orgãos governamentais e que, teoricamente, apresenta um delineamento eficiente e eficaz. Na prática, no entanto, a eficiência deste sistema depende completamente da adesão de todos os atores envolvidos (produtores rurais, revendedores, fabricantes de agrotóxicos e poder público) e justamente por isso, não tem sido efetiva. Se um elo dessa cadeia não estiver comprometido com seus deveres e responsabilidades, todo o restante será afetado.

Vale ressaltar que, para estar comprometido, cada elo deve estar em condições adequadas para isso, não sendo tão simples criar e fazer funcionar um sistema sem que haja condições ótimas para todos os envolvidos. Sendo assim, a identificação de falhas e a sugestão de possíveis melhorias devem ser constantes. Para tanto, considera-se que os passos mais importantes a serem seguidos pelos municípios é a elaboração de seus PMGIRS e um controle severo sobre o uso indiscriminado e intensivo de agrotóxicos.

O PMGIRS deve englobar os mais diversos tipos de resíduos gerados e levar em conta as particularidades de cada município ou região (no caso dos consórcios 
intermunicipais), como características culturais e de geração de renda, servindo como guias e ferramentas integradoras do sistema de logística reversa das EVAs e de outros resíduos. Para a elaboração e manutenção do plano, os gestores devem considerar o controle social, caracterizado como um conjunto de mecanismos e procedimentos que garantam à sociedade informações e participação nos processos de formulação, implementação e avaliação das políticas públicas relacionadas aos resíduos sólidos (BRASIL, 2010).

A participação popular na elaboração e manutenção do PMGIRS é essencial, pois permitirá compreender as dificuldade dos atores envolvidos em cumprir seu papel dentro daquilo que o plano propõe, principalmente produtores e revendedores de agrotóxicos, no que tange à questão do recolhimento de EVAs. Além disso, é importante levar em consideração que a elaboração do plano garante aos municípios direito a incentivos fiscais, financeiros e creditícios, o que é muito interessante para municípios pobres e sem estrutura, como Bom Repouso.

Cabe lembrar que, de acordo com a PNRS, o benefício por incentivos ou financiamentos de entidades federais de crédito ou fomento serão primeiramente disponibilizados para municípios que optarem por soluções consorciadas intermunicipais, incluída a elaboração e implementação de planos intermunicipais, ou que se inserirem de forma voluntária nos planos microrregionais de resíduos sólidos e para municípios que implantarem a coleta seletiva com a participação de cooperativas ou outras formas de associação de catadores de materiais reutilizáveis e recicláveis formadas por pessoas físicas de baixa renda .

Dessa forma, as soluções consorciadas municipais podem ser interessantes para Bom Repouso e outros municípios próximos, que também possuem menos de vinte mil habitantes e os mesmos problemas relacionados às EVAs. Consequentemente, seria uma forma de adquirir mais recursos financeiros para invertir na infraestrutura necessária para realizar a logística reversa das EVAs de forma eficiente.

Outro ponto a ser considerado em relação à utilização de agrotóxicos e destinação final de EVAs é a dificuldade que os próprios órgãos fiscalizadores têm em relação à organização de dados. Embora rapidamente disponibilizadas pelo IMA, as tabelas contendo informações sobre a comercialização de agrotóxicos em Bom Repouso não estavam bem organizadas, apresentando medidas imprecisas e sem sequer haver uma separação destes dados por períodos dentro de um mesmo ano. 
No caso das informações sobre recolhimento de EVAs, obtidas na central de recolhimento de Pouso Alegre, em alguns registros não há como identificar as capacidades das embalagens devolvidas, uma vez que há um total do peso de várias embalagens juntas.

Considera-se que, quanto mais claros e completos os registros, melhor para a gestão dos dados. No que tange às EVAs, acredita-se que dados bem organizados e registros mais completos permitirão uma melhor análise comparativa entre os dados de venda de agrotóxicos e devolução de EVAs, deixando de ser apenas um diagnóstico para se tornar um indicador de eficiência. Deste modo, esta melhor sistematização das informações contribuirá para a gestão mais eficiente destes resíduos, podendo ser um primeiro indicador da necessidade de intervenções no sistema. Se há discrepância entre os dados de venda de agrotóxicos e de recolhimento de EVAs, este é um primeiro alerta de que há deficiências no sistema e algo deve ser melhorado.

Com relação à fiscalização em relação à destinação adequada de EVAs, considera-se que a parte prática desse processo não é efetiva. A análise de dados e dos relatos das entrevistas relativos ao caso de estudo mostra um número elevado de EVAs sem destinação correta.

Isso demonstra que o número de fiscalizações não é suficiente e que muitos produtores, em consequência, não se intimidam e realizam a destinação incorreta, por vezes queimando e enterrando as EVAs para que não haja rastros de sua ação criminosa. Esta realidade foi constatada em Bom Repouso, tanto em visitas a propriedades, onde se visualizou restos de embalagens queimadas, quanto nos relatos de entrevistas. Considera-se que a mesma aconteça em outros municípios semelhantes.

No que diz respeito ao posicionamento de gestores municipais em relação às EVAs, considera-se que haja omissão e que os mesmos, muitas vezes, se mantêm alheios aos problemas decorrentes da destinação inadequada das mesmas.

No caso de estudo, por exemplo, constatou-se que a prefeitura conta com apenas um profissional qualificado para lidar com a logística reversa das EVAs. Em entrevista, este afirmou não ter voz ativa nas pautas de discussões com o prefeito e nem com a câmara dos vereadores, os quais parecem não considerar prioritário as questões ambientais e de saúde pública ligadas à gestão desses resíduos. Seu 
papel, portanto, tem sido apenas orientar os produtores a respeito de algumas questões básicas sobre a destinação das EVAs.

Vale salientar que também há omissão do inpEV, que baseia-se nos resultados nacionais para afirmar sua eficiência. Após a realização dessa pesquisa, estes resultados passam a ser questionáveis e suscitam um esclarecimento sobre como tem sido feitas as estatísticas que provam seus quase $95 \%$ de eficiência no recolhimento de EVAs.

Recomenda-se para novas pesquisas o desenvolvimento de ferramentas e indicadores para avaliar com mais precisão a eficiência do recolhimento de EVAs, bem como a criação de políticas públicas que possam auxiliar na gestão desses resíduos. 


\section{REFERÊNCIAS}

AL ZADJALI, S. et al. Disposal of pesticide waste from agricultural production in the Al-Batinah region of Northern Oman. The Science of the Total Environment, v. 463-464, p.237-242, Oct. 2013.

ANDRADE, R.M. A Gestão de resíduos sólidos urbanos no Brasil frente às questões da globalização. REDE - revista eletrônica do prodema, v.6, n.1, p.7-22, mar. 2011.

ASSOCIAÇÃO BRASILEIRA DE NORMAS TÉCNICAS. NBR 10004 - resíduos sólidos - classificação. Rio de Janeiro, 2004.

BARREIRA, L.P.; PHILLIPI JUNIOR, A. A Problemática dos resíduos de embalagens de agrotóxicos no Brasil. In: CONGRESSO INTERAMERICANO DE INGENIERÍA SANITARIA Y AMBIENTAL, 28., 2000, Cancún. Annales... Cancún: Asociación Interamericana de Ingineria Sanitaria y Ambiental, 2000.

BOMBARDI, L.M. A Intoxicação por agrotóxicos no Brasil e a violação dos direitos humanos. In: MERLINO, T.; MENDONÇA, M.L. (Org.). Direitos humanos no Brasil 2011: relatório. São Paulo: Rede Social de Justiça e Direitos Humanos, 2011.

BOULOMITYS, V.T.G. ; BRESAOLA JUNIOR, R. Problemática no uso da terra e no manejo agrícola da bataticultura em Bueno Brandão, MG. Sociedade e Natureza, v.25, n.2, p.303-315, maio/ago. 2013. Disponível

em:<http://www.scielo.br/pdf/sn/v25n2/a08v25n2.pdf>. Acesso em: 10 mar. 2014.

BOWERSOX, D.J.; CLOSS, D.J. Logistical management: the integrated supply chain process. London: McGraw-Hill International, 1996.

BRASIL. Decreto n. $^{\circ}$ 24.114, de 12 de abril de 1934. Aprova o regulamento de defesa sanitária vegetal. Diário Oficial da União, Brasília, Seção 1, 4 maio 1934, p.8514. Disponível em:<http://www.agroporto.com/pdf/dec24114.pdf>. Acesso em: 5 mar. 2014.

BRASIL. Decreto $n^{\circ} 4.074$, de 4 de janeiro de 2002. Regulamenta a Lei no 7.802 , de 11 de julho de 1989, que dispõe sobre a pesquisa, a experimentação, a produção, a embalagem e rotulagem, o transporte, o armazenamento, a comercialização, a propaganda comercial, a utilização, a importação, a exportação, o destino final dos resíduos e embalagens, o registro, a classificação, o controle, a inspeção e a fiscalização de agrotóxicos, seus componentes e afins, e dá outras providências.

Diário Oficial da União, Brasília, 8 jan. 2002. Disponível em:<http://www.mma.gov.br/port/conama/legiabre.cfm?codlegi=515>. Acesso em: 6 mar. 2014.

BRASIL. Decreto $n^{0} 7.404$, de 23 de dezembro de 2010. Regulamenta a Lei $n^{\circ}$ 12.305, de 2 de agosto de 2010, que institui a Política Nacional de Resíduos Sólidos, cria o Comitê Interministerial da Política Nacional de Resíduos Sólidos e o Comitê Orientador para a Implantação dos sistemas de Logística Reversa, e dá outras 
providências. Diário Oficial da União, Brasília, 23 dez. 2010. Disponível em:<http:www.planalto.gov.br/ccivil_03/_ato2007-2010/2010/decretod7404.htm>. Acesso em:5 mar. 2014.

BRASIL. Lei $\mathrm{n}^{0} 6.360$, de 23 de setembro de 1976. Dispõe sobre a Vigilância Sanitária a que ficam sujeitos os Medicamentos, as Drogas, os Insumos Farmacêuticos e Correlatos, Cosméticos, Saneantes e Outros Produtos, e dá outras Providências. Diário Oficial da União, Brasília, 24 set. 1976. Disponível em:<http://www.camara.gov.br/sileg/integras/395646.pdf>. Acesso em: 5 mar. 2014.

BRASIL. Lei $\mathrm{n}^{0}$ 7.802, de 11 de julho de 1989. Dispõe sobre a pesquisa, a experimentação, a produção, a embalagem e rotulagem, o transporte, o armazenamento, a comercialização, a propaganda comercial, a utilização, a importação, a exportação, o destino final dos resíduos e embalagens, o registro, a classificação, o controle, a inspeção e a fiscalização de agrotóxicos, seus componentes e afins, e dá outras providências. Diário Oficial da União, Brasília, 12 jul. 1989. Disponível em:<http://www.planalto.gov.br/ccivil_03/leis/l7802.htm>. Acesso em: 6 mar. 2014.

BRASIL. Lei $n^{0} 9.605$ de 12 de fevereiro de 1998. Dispôes sobre as sanções penais e administrativas derivadas de condutas e atividades lesivas ao meio ambiente, e dá outras providências. Diário Oficial da União, Brasília, 13 fev. 1998. Disponível em:<http://www2.camara.leg.br/legin/fed/lei/1998/lei-9605-12-fevereiro-1998365397-normaatualizada-pl.pdf>. Acesso em: 6 mar. 2014.

BRASIL. Lei $n^{\circ} 9.974$, de 6 de junho de 2000. Altera a Lei no 7.802, de 11 de julho de 1989, que dispõe sobre a pesquisa, a experimentação, a produção, a embalagem e rotulagem, o transporte, o armazenamento, a comercialização, a propaganda comercial, a utilização, a importação, a exportação, o destino final dos resíduos e embalagens, o registro, a classificação, o controle, a inspeção e a fiscalização de agrotóxicos, seus componentes e afins, e dá outras providências. Diário Oficial da União, Brasília, 7 jun. 2000. Disponível em:<http://www.emater.tche.br/site/br/arquivos/area/legislacao/federal/lflei9974.pdf>. Acesso em: 10 mar. 2014.

BRASIL. Lei $n^{0} 11.445$, de 5 de janeiro de 2007. Estabelece diretrizes nacionais para o saneamento básico; altera as Leis nos 6.766, de 19 de dezembro de 1979, 8.036, de 11 de maio de 1990, 8.666, de 21 de junho de 1993, 8.987, de 13 de fevereiro de 1995; revoga a Lei no 6.528, de 11 de maio de 1978; e dá outras providências. Diário Oficial da União, Brasília, 8 jan. 2007. Disponível em:<http://www.cedae.com.br/ri/Regulacao_Lei_11445.pdf>. Acesso em: 10 mar. 2014.

BRASIL. Lei $n^{\circ} 12.305$, de 2 de agosto de 2010. Institui a Política Nacional de Resíduos sólidos; altera a Lei $n^{0}$ 9.065, de 12 de fevereiro de 1998, e dá outras providências. Diário Oficial da União, Brasília, 3 ago. 2010. Disponível em:< http://www.mma.gov.br/port/conama/legiabre.cfm?codlegi=636>. Acesso em: 2 fev. 2014.

BRASIL. Ministério da Agricultura. Produto interno bruto da agropecuária deve 
ser de R\$ 1,1 trilhão. Disponível

em:<http://www.agricultura.gov.br/comunicacao/noticias/2014/12/produto-internobruto-da-agropecuaria-deve-ser-de-rs-1-trilhao>. Acesso em: 6 jan. 2015.

BRASIL. Ministério do Meio Ambiente. Linha do tempo da política nacional de resíduos sólidos. Disponível em:<http://www.mma.gov.br/cidades-

sustentaveis/residuos-solidos/politica-nacional-de-residuos-solidos/linha-do-tempo>. Acesso em: 5 maio 2014.

BRASIL. Ministério do Meio Ambiente. Conselho Nacional do Meio Ambiente.

Resolução CONAMA n 334 de 3 de abril de 2003. Disponível em:<http://www.mma.gov.br/port/conama/res/res03/res33403.xml>. Acesso em: 10 mar. 2014.

BRUM, A.J.A. Modernização da agricultura: trigo e soja. In: MODERNIZAÇÃO da agricultura: trigo e soja. Petrópolis: FIDENE, 1988. p.31-89.

BUSER, H.R. Atrazine and other s-triazine herbicides in lakes and in rain in Switzerland. Environmental Science and Technology, v.24, p.1049-1058, 1990.

CAMPANHOLA, C.; BETTIOL, N. Programa sobre o uso de agrotóxicos no Brasil. In: . (Ed.). Métodos alternativos de controle fitossanitário. Jaguariúna: Embrapa Meio Ambiente, 2003. p.13-51.

CARBONE, G.T.; SATO, G.S.; MOORI, R.G. Logística reversa para embalagens de agrotóxicos no Brasil : uma visão sobre conceitos e práticas operacionais. In: CONGRESSO DA SOBER, 43., 2005, Ribeirão Preto. Disponível em:<http://lms.ead1.com.br/upload/biblioteca/curso_8496/1zfpwneyw9.pdf>. Acesso em: 5 fev. 2014.

CARNEIRO, F.F. et al. Dossiê ABRASCO - um alerta sobre os impactos dos agrotóxicos na saúde. Rio de Janeiro: EPSJV; São Paulo: Expressão Popular, 2015.

CASTRO, J.S.M.; CONFALONIERI, U. Uso de agrotóxicos no município de Cachoeiras de Macacu ( RJ ). Ciência e Saúde Coletiva, v.10, n.2, p.473-482, 2005.

COMETTI, J.L.S. Logística reversa das embalagens de agrotóxicos no Brasil: um caminho sustentável?. 2009. Dissertação (Mestrado) - Centro de Desenvolvimento Sustentável, Universidade de Brasília, Brasilia, 2009. Disponível em:<http://www.cprh.pe.gov.br/ARQUIVOS_ANEXO/Dissertaçao_Jose_Luis_Comett i.pdf>. Acesso em: 21 fev. 2014.

COMETTI, J.L.S.; ALVES, I.T.G. Responsabilização pós-consumo e logística reversa : o caso das embalagens de agrotóxicos no Brasil. Sustentabilidade em Debate, mai. 2010. Disponível em:<http://periodicos.unb.br/index.php/sust/article/view/727/444>. Acesso em: 6 fev. 2014. 
gerenciamento integra- do. 2.ed. São Paulo: IPT, 2000.

CÓRDOBA, R.E. Estudo do sistema de gerencimento integrado de resíduos de construção e demolição do município de São Carlos - SP. 2010. 406p.

Dissertação (Mestrado) - Escola de Engenharia de São Carlos, Universidade de São Paulo, São Carlos, 2010.

. Estudo do potencial de contaminação de lixiviados gerados em aterros de resíduos da construção civil por meio de simulações em colunas de lixiviação. 2014. 340p. Tese (Doutorado) - Escola de Engenharia de São Carlos, Universidade de São Paulo, São Carlos, 2014.

COSTA, L.; VALLE, R. Logística reversa: importância, fatores para a aplicação e contexto brasileiro. In: SIMPÓSIO DE EXCELÊNCIA EM GESTÃO E TECNOLOGIA LOGÍSTICA, 3., 2006. Disponível

em:<http://www.aedb.br/seget/arquivos/artigos06/616_Logistica_Reversa_SEGeT_0 6.pdf>. Acesso em : 25 jun. 2015.

CUNHA, G.P.Q. Caracterização ambiental da região de montante do rio MogiGuaçu ( Bom Repouso - MG ): estratégias para replicabilidade e diretrizes para elaboração do plano de adequação ambiental. 2009. Tese (Doutorado) - Escola de Engenharia de São Carlos, Universidade de São Paulo, São Carlos, 2009.

DAMALAS, C.A.; TELIDIS, G.K.; THANOS, S.D. Assessing farmers' practices on disposal of pesticide waste after use. The Science of the Total Environment, v.390, n.2-3, p.341-5, Feb. 2008.

DOMINGUES, M.R. et al. Agrotóxicos : risco à saúde do trabalhador rural = Pesticides : risk to rural worker health. Semina: ciências biológicas e da saúde, v.25, p.45-54, 2004.

DUARTE, V.S. Studies for implementation of neozygites floridana as control agent of two-spotted spider mite in strawberry. 2013. 97p. Tese (Doutorado) Escola Superior de Agricultura Luiz de Queiroz, Universidade de São Paulo, 2013.

ENVIRONMENTAL PROTECTION AGENCY. Technical background paper: empty pesticide containers (PPP). Washington: Department of Agriculture, Food and the Marine, 2012.

ESPÍNDOLA, É.A. Analise da percepção de risco do uso de agrotóxicos em áreas rurais: um estudo junto aos agricultores no município de Bom Repouso (MG). 2011. 155p. Tese (Doutorado) - Escola de Engenharia de São Carlos, Universidade de São Paulo, São Carlos, 2011.

ESPÍNDOLA, E.L.G.; BRIGANTE, J. (Ed.). Projeto Mogi-Guaçu. São Carlos: Rima, 2009.

FOOD AND AGRICULTURE ORGANIZATION OF THE UNITED NATIONS. Guidelines on management options for empty pesticide containers. In: INTERNATIONAL Code of Conduct on the Distribution and Use of Pesticides 
Guidelines. Washington, 2008.

FERRER, G.; WHYBARK, C.D. From garbage to goods: Successful remanufacturing systems and skills. Business Horizons, v.43, n.6, p.55-64, 2000.

FLEISCHMANN, M. Quantitative models for reverse logistics. New York: Springer, 2001.

FRICKE, K. et al. Capacitação e pesquisa fundamental, a fim de gerar metodologia de análise para o desenvolvimento de projeto para uma instalação de tratamento mecânico-biológico (TMB) com fermentacão integrada na cidade de Jundiaí.Panorama geral. Jundiaí: i-NoPa - Programa Novas Parcerias Integradas, 2015.

FUNARI, E. et al. Pesticide levels in ground water: value and limitations of monitoring. In: VIGHI, M.; FUNARU, E. (Ed.). Pesticide risk in groundwater. Boca Raton: CRC Press, 1995. p.3-44.

GLOTFELTY, D.E.; SEIBER, J.N.; LILJEDAHL, L.A. Pesticides in fog. Nature, v.325, p.602-605, 1987.

GREGOR, D.J.; GUMMER, W.D. Evidence of atmospheric transport and deposition of organochlorine pesticides and polychlorinated biphenyls in Canadian artic snow. Environmental Science and Technology, v.23, p.561-565, 1989.

GROVER, R. et al. Environmental fate of trifluralin. Review of Environmental Contamination and Toxicology, v.153, p.1-64, 1997.

GUIMARÃES, J.R.D. Glifosato na mira. Disponível em:<http://cienciahoje.uol.com.br/colunas/terra-em-transe/glifosato-na-mira> . Acesso em: 3 dez. 2015.

INSTITUTO BRASILEIRO DE GEOGRAFIA E ESTATÍSTICA. IBGE Cidades. Brasília, 2010. Disponível em:<http://www.cidades.ibge.gov.br/xtras/perfil.php?lang=\&codmun=310790>. Acesso em: 13 mar. 2013.

INSTITUTO BRASILEIRO DO MEIO AMBIENTE E DOS RECURSOS NATURAIS RENOVÁVEIS. Produtos agrotóxicos e afins comercializados em 2009 no Brasil: uma abordagem ambiental. Brasília, 2010. Disponível em:<file:///C:/Users/Mayra/Desktop/MESTRADO USP 2013/Manuais/Produtos_agrotoxicos_comercializados_brasil_2009 - IBAMA.pdf>. Acesso em: 5 dez. 2013.

INSTITUTO BRASILEIRO DO MEIO AMBIENTE E DOS RECURSOS NATURAIS RENOVÁVEIS. Boletim de comercialização de agrotóxicos e afins - histórico de vendas de 2000 a 2012 . Brasília: Ministèrio do Meio Ambeiente, 2013.

INSTITUTO DE ECONOMIA AGRÍCOLA. Defensivos agrícolas: em 2014, faturamento do segmento foi o destaque. Análises e Indicadores do 
Agronegócio, v.10, n.5, p.7, 2015. Disponível

em:<http://www.iea.sp.gov.br/ftpiea/AIA/AIA-33-2015.pdf>. Acesso em: 12 nov. 2015.

INSTITUTO NACIONAL DE PROCESSAMENTO DE EMBALAGENS VAZIAS. Sobre o sitema. 2011. Disponível em:<http://www.inpev.org.br/sistema-campolimpo/sobre-o-sistema>. Acesso em: 14 abr. 2014.

Sistema campo limpo - unidades de recebimento. 2012. Disponível em:<https://www.inpev.org.br/downloads/materiais-institucionais/bannerresultados.pdf>. Acesso em: 14 abr. 2014.

. Relatório de sustentabiliade 2012. 2013. Disponível em:<http://relatoweb.com.br/inpev/2012/pdf/inpEV_RS2012_PT.pdf >. Acesso em: 15 fev. 2014.

INSTITUTO NACIONAL DE PROCESSAMENTO DE EMBALAGENS VAZIAS. Dados de devolução da central de recolhimento de embalagens vazias de Pouso Alegre, MG - 2010 a 2014. [S.I.:s.n], 2014.

INSTITUTO NACIONAL DE PROCESSAMENTO DE EMBALAGENS VAZIAS. Relatório de sustentabilidade 2013. 2014a. Disponível em:<http://relatoweb.com.br/inpev/2013/pdf/RS2013inpEV_PT.pdf>. Acesso em: 6 jul. 2014.

. Logística reversa. 2014b. Disponível em:<http://www.inpev.org.br/logistica-reversa/destinacao-dasembalagens/localizacao-das-unidades?estado=Minas Gerais\&tipo=Posto\&municipio=8f652e 76-f4ab-4ea3-9d1be468e5d90a8a\&municipioNome=Pouso Alegre>. Acesso em: 22 jan. 2014.

. Sistema campo limpo - fluxo do sistema. 2014c. Disponível em:<http://www.inpev.org.br/sistema-campo-limpo/fluxo-do-sistema>. Acesso em: 14 abr. 2014.

. Relatório de sustentabilidade 2014. 2015. Disponível em:<http://www.inpev.org.br/relatoriosustentabilidade/2014/pdf/inpEVRS2014_completo_pt_bx.pdf>. Acesso em: 7 out. 2015.

INSTITUTO NACIONAL DO CÂNCER. Posicionamento do Instituto Nacional de Câncer José Alencar Gomes da Silva acerca dos agrotóxicos. 2015. Disponível em:<http://www1.inca.gov.br/inca/Arquivos/comunicacao/posicionamento_do_inca_s obre_os_agrotoxicos_06_abr_15.pdf>. Acesso em: 10 maio 2015.

INSTITUTO DE PESQUISA ECONOMICA APLICADA. Diagnóstico dos resíduos sólidos do setor agrossilvopastoril - maio 2013. Relatório de pesquisa. Brasília, 2013. Disponível em:<http://www.ipea.gov.br/portal/images/stories/PDFs/relatoriopesquisa/130531_rel atorio_diagnostico_residuos_agrossilvopastoril.pdf>. Acesso em: 15 maio 2014. 
KRUMWIEDE, D.W.; SHEU, C. A Model for reverse logistics entry by third-party providers. Omega, v.30, n.5, p.325-333, 2002.

LAABS, V. et al. Pesticides in surface water, sediment and rainfall of the northeastern Pantanal basin, Brazil. Journal Environmental Quality, v.31, p.16361648, 2002.

LAKATOS, E.M.; MARCONI, M.A. Fundamentos de metodologia científica. 5.ed. São Paulo: Atlas, 2003.

LANDON, M.; JACOBSEN, J.; JOHNSON, G. Pesticide management for water quality protection. Bozeman: Montana State University,1990.

MACHADO NETO, J.G. Ecotoxicologia dos agrotóxicos e saúde ocupacional: 5a. aula - embalagens de agrotóxicos. Jaboticabal: Faculdade de Ciências Agrárias e Veterinárias, Departamento de Fitossanidade, 2015. Disponível em:<http://www.fcav.unesp.br/Home/departamentos/fitossanidade/JOAQUIMGONCA LVESMACHADONETO/5a-embalagens-03-09-2015.pdf>. Acesso em: 12 dez. 2015.

MALINOWSKI, C.E.; MALINOWSKI, M.O.S.O. Uso de agrotóxicos e a tutela penal da Lei no 7802/89. "Direito e Direitos" Revista Jurídica Eletrônica da UEMS, v.1, n.2, p.16, 2011. Disponível

em:<http://periodicos.uems.br/novo/index.php/direitoedireitos/article/viewFile/87/788 >. Acesso em: 24 mar. 2014.

MINAS GERAIS. Decreto no 23.698, de 23 de julho de 1984. Diário do Executivo, 24 jul. 1984. Disponível

em:<http://www.siam.mg.gov.br/sla/download.pdf?idNorma=1137>. Acesso em: 7 set. 2015.

MINAS GERAIS. Decreto $n^{0} 33945$ de 14 de outubro de 1992. Diário do Executivo, 19 set. 1992. Disponível em:<http://www.siam.mg.gov.br/sla/download.pdf?idNorma=1357>. Acesso em: 24 set. 2015.

MINAS GERAIS. Decreto $n^{\circ} 41203$ de 8 de agosto de 2000. Diário do Executivo, 9 ago. 2000. Disponível

em:<http://www.siam.mg.gov.br/sla/download.pdf?idNorma=1692>. Acesso em: 24 set. 2015.

MINAS GERAIS. Lei n ${ }^{0}$ 9.121, de 30 de dezembro de 1985. Diário do Executivo, 31 dez. 1985. Disponível em:<http://www.enge.com.br/LeiEst_09121_85.pdf>. Acesso em: 25 set. 2015.

MINAS GERAIS. Lei n¹0545 de 13 de dezembro de 1991. Diário do Executivo, 14 dez. 1991. Disponível

em:<http://www.siam.mg.gov.br/sla/download.pdf?idNorma=9272>. Acesso em: 24 set. 2015. 
MINAS GERAIS. Conselho Estadual de Política Ambiental. Deliberação normativa COPAM $\mathbf{n}^{\circ} 74$ de 9 se setembro de 2004. 2004a. Disponível em:<http://sisemanet.meioambiente.mg.gov.br/mbpo/recursos/DeliberaNormativa74. pdf $>$. Acesso em: 5 abr. 2014.

MINAS GERAIS. Conselho Estadual de Política Ambiental. Deliberação normativa COPAM $n^{\circ} 109$ de 30 de maio de 2007. 2007a. Disponível em:<https://www.legisweb.com.br/legislacao/?id=141597>. Acesso em: 10 abr. 2014.

MINAS GERAIS. Instituto Mineiro De Agropecuária. Tabela de vendas de agrotóxicos no município de Bom Repouso, MG - 2012-2014. [S.I.:s.n.], 2014.

MINAS GERAIS. Instituto Mineiro De Agropecuária. Portaria Nº50 de 16 de junho de 2004. 2004b. Disponível

em:<http://www.ima.mg.gov.br/portarias/doc_download/265-portaria-no-650.>. Acesso em: 24 mar. 2014.

MINAS GERAIS. Instituto Mineiro De Agropecuária. Portaria nº 862 de 29 de agosto de 2007. 2007b. Disponível

em:<http://www.ima.mg.gov.br/portarias/doc_download/346-portaria-no-862.>. Acesso em: 24 set. 2015.

MORAES, G.J.; FLECHTMANN, C.H.W. Ácaros encontrados em diferentes espécies vegetais de importância econômica. In: MORAES, G.J.; FLECHTMANN, C.H.W. Manual de acarologia: acarologia básica e ácaros de plantas cultivadas no Brasil. Ribeirão Preto: Holos, 2008. Cap.9, p.106-208.

MUELLER, C.F. Logística reversa: meio-ambiente e produtividade. Porto Alegre: Grupo de Estudos Logísticos GELOG; Universidade Federal de Santa Catarina, 2005. Disponível em:<http://limpezapublica.com.br/textos/artigo01_1.pdf>. Acesso em: 10 ago. 2015.

MUTHA, A.; POKHAREL, S. Strategic network design for reverse logistics and remanufacturing using new and old product modules. Computers and Industrial Engineering, v.56, n.1, p.334-346, 2009.

NISHIKAWA, D.L.L. Alternativas ao modelo hegemônico da agricultura: o caso da associação de produtores rurais dos garcias no municípi o de Bom Repouso (MG). 2012. Tese (Doutorado) - Faculdade de Ciências e Letras, Universidade Estadual Paulista "Júlio de Mesquita Filho", Araraquara, 2012.

NUNES, M.E.T. Avaliação dos efeitos de agrotóxicos sobre a fauna edáfica por meio de ensaios ecotoxicológicos com Eisenia andrei (Annelida, Oligochaeta) e com comunidade natural de solo. 2010. Tese (Doutorado) - Escola de Engenharia de São Carlos, Universidade de São Paulo, São Carlos, 2010.

NUNES, G.S.; RIBEIRO, M.L. Pesticidas: uso, legislação e controle. Pesticidas: revista de ecotoxicologia e meio ambiente, v.9, p.31-44, jan./dez. 1999. 
PASQUALI, L. Composição gravimétrica de resíduos sólidos recicláveis domiciliares no meio rural de Chopinzinho - PR. 2012. Dissertação (Mestrado) Universidade Tecnológica Federal do Paraná, Pato Branco, 2012. Disponnóivel em:<http://repositorio.utfpr.edu.br:8080/jspui/bitstream/1/415/1/PB_PPGDR_M_Pasq uali\%2c Luiz_2012.pdf>. Acesso em: 10 mar. 2014.

PAULO, S.R. Reflexões sobre o modo de produção capitalista e a geração de resíduos sólidos urbanos. Revista Mato-Grossense de Geografia, p.124-144, 2013.

PERES, F.; MOREIRA, J.C.; DUBOIS, G.S. Agrotóxicos, saúde e ambiente: uma introdução ao tema. In: PERES, F.; MOREIRA, J.C. É veneno ou remédio? Agrotóxicos, saúde e ambiente. Rio de Janeiro: Fiocruz, Rio de Janeiro, 2003. p.2141. Disponível em:<http://static.scielo.org/scielobooks/sg3mt/pdf/peres9788575413173.pdf>. Acesso em: 15 jan. 2014.

PERES, F.; MOREIRA, J.C. Saúde e ambiente em sua relação com o consumo de agrotóxicos em um pólo agrícola do Estado do Rio de Janeiro, Brasil. Cadernos de Saúde Pública. Saúde, ambiente e agrotóxicos. Rio de Janeiro, 2007. Disponível em:<http://www.scielosp.org/pdf/csp/v23s4/13.pdf>. Acesso em: 14 fev. 2014.

RITCHIE, L. et al. The Benefits of reverse logistics: the case of the Manchester Royal Infirmary Pharmacy. Supply Chain Management: an international journal, v.5, n.5, p.226-234, 2000.

SCHALCH, V.; CASTRO, M.A.S.; CÓRDOBA, R.E. Tratamento e disposição final adequada de resíduos sólidos urbanos. São Carlos: Núcleo de Estudo e Pesquisa em Resíduos Sólidos, EESC/USP, 2014.

SCHALCH, V. et al. Gestão e gerenciamento de resíduos sólidos. São Carlos: Departamento de Hidráulica e Saneamento, EESC/USP, 2002.

SCHOMBURG, C.J.; GLOTFELTY, D.E. Pesticide occurrence and distribution in fog collected near Monterrey, California. Environmental Science and Technology, v.25, p.155-160, 1991.

SEVERINO, A.J. Metodologia do trabalho científico. 23.ed. São Paulo: Côrtez, 2007.

SILVA, C.M.M.S.; FAY, E.F. Agrotóxicos: apectos gerais. In: . (Ed.).

Agrotóxicos e ambiente. Brasília: Embrapa, 2004.

SILVA, M.F.O.E; COSTA, L.M. A Indústria de defensivos agrícolas. BNDES Setorial, n.35, p.233-276, 2012. Disponível em:<https://web.bndes.gov.br/bib/jspui/bitstream/1408/1513/1/A set.35_A ind stria de defensivos agrícolas_P.pdf>. Acesso em: 8 ago. 2015.

SILVA, P.A. Qualidade de morangos cultivados na região de Lavras, MG, armazenados em temperatura ambiente. 2007. Dissertação (Mestrado) Universidade Federal de Lavras, Lavras, 2007. 
SILVA, T.M.B. Destinação das embalagens de agrotóxicos utilizados pelos pequenos agricultores das cidades de Bananeiras e Solânea - PB: uma perspectiva de educação ambiental. 2012. Monografia (Trabalho de Conclusão de Curso) - Centro de Ciencias Bilológicas e de Saúde, Universidade Estadual da Paraíba, Campina Grande, 2012. Disponível em:<http://dspace.bc.uepb.edu.br:8080/jspui/bitstream/123456789/689/1/PDF Thatiana Maria Borges Silva.pdf>. Acesso em: 15 abr. 2014.

SILVA JUNIOR, D.F. Legislação federal - agrotóxicos e afins. 2.ed. Piracicaba: FEALQ, 2008.

SINDICATO NACIONAL DAS INDÚSTRIAS DE DEFENSIVOS AGRÍCOLAS. Vendas de defensivos agrícolas são recordes e vão a US\$ 8,5 bi em 2011. Folha de São Paulo, São Paulo, 20 abr. 2012. Disponível em:<http://bit.do/sindag2256>. Acesso em: abr. 2014.

. Uso indevido de agrotóxicos afeta $20 \%$ de grãos e fruta. Sindag News, 2013a. Disponível em:<http://www.sindag.com.br/noticia.php?News_ID=2363>. Acesso em: 10 abr. 2014.

. País cresce no mercado de defensivos. Sindag News, 2013b. Disponível em:<http://www.sindag.com.br/noticia.php?News_ID=2331>. Acesso em: $10 \mathrm{abr}$. 2014.

SINDICATO NACIONAL DA INDÚSTRIA DE PRODUTOS PARA DEFESA VEGETAL. Recorde, venda de defensivo no país em 2013 atingiu US\$ 11,5 bi. Sindiveg News Online, 26 jun. 2014. Disponível em:<http://www.sindiveg.org.br/noticiaonline.php?cod=2413>. Acesso em: 10 ago 2014.

SIQUEIRA, D.F. et al. Análise da exposição de trabalhadores rurais a agrotóxicos. Revista Brasileira em Promoção da Saúde, v.26, n.2, 2013. Disponível em:<http://www.unifor.br/images/pdfs/rbps/2013.2_artigo4.pdf>. Acesso em: 25 jan. 2014.

SNIS. Sistema Nacional de Informação em Saneamento. Diagnóstico Água e Esgoto. Brasil, 2013. Disponível em: <http://www.snis.gov.br/diagnostico-agua-eesgotos/diagnostico-ae-2013>. Acesso em: 2 maio 2014.

SPADOTTO, C.A. et al. Monitoramento do risco ambiental de agrotóxicos: princípios e recomendações. Jaguariúna: EMBRAPA, 2004. Disponível em:<http://www.cnpma.embrapa.br/download/documentos_42.pdf>. Acesso em: 5 maio 2014.

TAVELLA, L.B. O Uso de agrotóxicos na agricultura e suas consequências toxicológicas e ambientais. Agropecuária Científica no Semi-Árido, p.6-12, 2011. Disponível em:<file:///C:/Users/Mayra/Desktop/MESTRADO USP 2013/Artigos/Artigo 11 - Leonardo Barreto Tavella.pdf>. Acesso em: 8 maio 2014. 
TIBBEN-LEMBKE, R.; ROGERS, D.S. Differences between forward and reverse logistics. Supply Chain Management: an international journal, v.7, n.5, p.271-282, 2002.

TROTTA, P. A Gestão de resíduos sólidos urbanos em Portugal. In: CONGRESSO NACIONAL DE EXCELÊNCIA EM GESTÃO, 7. 2011. Disponível em:<http://www.excelenciaemgestao.org/portals/2/documents/cneg7/anais/t11_0350 _2173.pdf>. Acesso em: 10 maio 2014.

VEIGA, M.M. Analysis of efficiency of waste reverse logistics for recycling. Waste management \& research: the journal of the International Solid Wastes and Public Cleansing Associatio, v.31, n.10, p.26-34, Oct. 2013. Disponível em:<http://www.ncbi.nlm.nih.gov/pubmed/23997069>. Acesso em: 2 fev. 2014.

. Flaws in Brazilian take-back program for pesticide containers in a small rural community. Management Research News, v.32, n.1, p.62-77, 2009. Disponível em:<http://www.emeraldinsight.com/10.1108/01409170910922032>. Acesso em: 2 fev. 2014.

VEIGA, M.M. et al. Análise da contaminação dos sistemas hídricos por agrotóxicos numa pequena comunidade rural do Sudeste do Brasil. Cadernos de Saúde Pública, v.22, n.11, p.2391-2399, 2006. Disponível em:<http://www.scielo.br/scielo.php?script=sci_arttext\&pid=S0102311X2006001100013\&lng=en\&nrm=iso\&tlng=pt/nhttp://www.scielosp.org/scielo.php? script=sci_arttext\&pid=S0102-311X2006001100013\&lng=en\&nrm=iso\&tlng=pt $>$. Acesso em: 2 fev. 2014. 


\section{APÊNDICES}




\section{Apêndice 1}

\section{ROTEIRO DE ENTREVISTA - Prefeitura}

Data:

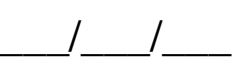

1) O que é de responsabilidade da prefeitura com relação a gestão de embalagens vazias de agrotóxicos no município de Bom Repouso?

2) Como a prefeitura orienta os produtores a respeito da destinação adequada de embalagens vazias de agrotóxicos no município?

3) Frente as possibilidades de melhorias (pontos de coleta, coleta itinerante), no que a prefeitura poderia contribuir?

4) Como a prefeitura enxerga a importância do Plano Municipal de Gestão Integrada de Resíduos Sólidos?

5) A prefeitura tem conhecimento do processo de logística reversa e sua importância diante da questão dos resíduos sólidos?

6) Observações complementares: 


\section{Apêndice 2}

\section{ROTEIRO DE ENTREVISTA - Revendas de Agrotóxicos}

Revenda 1 - Data:

1) Tem conhecimento da Lei dos Agrotóxicos (Lei Federal 7802 de 1989 e Lei 9974 de 2000)?

2) Como a revenda orienta os produtores a respeito da destinação adequada de embalagens vazias de agrotóxicos no município?

3) Quais as dificuldades encontradas para o recebimento das embalagens vazias?

4) Frente as possíveis soluções (pontos de coleta, coleta itinerante), o que sugere?

5) Tem conhecimento dos riscos associados a possibilidade de contaminação dos recursos naturais e da população humana devido ao descarte inadequado de embalagens vazias de agrotóxicos.

6) Observações complementares: 


\section{Apêndice 3}

\section{ROTEIRO DE ENTREVISTA - Sindicato dos Trabalhadores Rurais de Bom Repouso}

Data:

1) Acha que os trabalhadores rurais tem conhecimento da Lei dos Agrotóxicos (Lei Federal 7802 de 1989 e Lei 9974 de 2000)?

2) O que é de responsabilidade dos trabalhadores rurais com relação a gestão de embalagens vazias de agrotóxicos no município de Bom Repouso?

3) Como o Sindicato orienta os trabalhadores rurais a respeito da destinação adequada de embalagens vazias de agrotóxicos no município?

4) Quais as dificuldades encontradas para a destinação adequada das embalagens vazias por parte dos trabalhadores rurais?

5) Frente as possibilidades de melhorias (pontos de coleta, coleta itinerante), o que os trabalhadores Rurais sugerem e no que poderiam contribuir?

6) Tem conhecimento dos riscos associados a possibilidade de contaminação dos recursos naturais e da população humana devido ao descarte inadequado de embalagens vazias de agrotóxicos.

7) Observações complementares: 


\section{Apêndice 4}

\section{ROTEIRO DE ENTREVISTA - Central INPEV - Pouso Alegre}

Data:

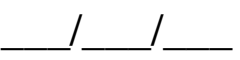

Responsável:

Como funciona a central com relação a:

- Funcionários

- Banco de dados

- Suporte (técnico, financeiro e de responsabilidade social)

- Parcerias

- Municípios atendidos

Como funciona a orientação aos produtores a respeito da destinação adequada de embalagens vazias de agrotóxicos no município?

Observações complementares: 


\section{Apêndice 5}

\section{TERMO DE SIGILO DE INFORMAÇÕES}

São Carlos, 20 de novembro de 2014.

Prezado/a

Eu, Mayra Rodrigues Silva, inscrita sob o CPF 089816326 93, mestranda do curso de pós-graduação em Ciências da Engenharia Ambiental da Universidade de São Paulo, me comprometo a não revelar quaisquer informações pessoais presentes nas gravações realizadas para composição de minha dissertação de mestrado intitulada "Recolhimento e destinação de embalagens vazias de agrotóxicos em pequenos municípios brasileiros: o caso do município de Bom Repouso, MG":

Certa de poder contar com a sua compreensão e colaboração, agradeço antecipadamente e coloco-me à disposição para quaisquer esclarecimentos que se façam necessários.

Atenciosamente,

Mayra Rodrigues Silva

(Mestranda em Ciências da Engenharia Ambiental - EESC - USP)

Contato: mayrabio@yahoo.com.br 


\title{
Apêndice 6
}

\section{Termos de Autorização para gravação}

\author{
AUTORIZAÇÃO PARA GRAVAÇÃO
}

$\mathrm{Eu}$, inscrito sob o $\mathrm{CPF}$ autorizo a gravação da entrevista conduzida pela mestranda Mayra Rodrigues Silva para composição de sua dissertação de Mestrado intitulada "Recolhimento e destinação de embalagens vazias de agrotóxicos em pequenos municípios brasileiros: o caso do município de Bom Repouso, MG". A mestranda se compromete a não revelar quaisquer informações pessoais presentes nas gravações.

Bom Repouso, 20 de novembro de 2014. 


\section{AUTORIZAÇÃO PARA GRAVAÇÃO E CITAÇÃO}

$\mathrm{Eu}$, inscrito sob o $\mathrm{CPF}$ autorizo a gravação da entrevista conduzida pela mestranda Mayra Rodrigues Silva para composição de sua dissertação de Mestrado intitulada "Recolhimento e destinação de embalagens vazias de agrotóxicos em pequenos municípios brasileiros: o caso do município de Bom Repouso, MG". A mestranda se compromete a não revelar quaisquer informações pessoais presentes nas gravações, sendo constante apenas a citação de meu cargo de responsabilidade na prefeitura.

Bom Repouso, 20 de novembro de 2014. 


\section{AUTORIZAÇÃO PARA GRAVAÇÃO E CITAÇÃO}

$\mathrm{Eu}$, inscrito sob o $\mathrm{CPF}$ autorizo a gravação da entrevista conduzida pela mestranda Mayra Rodrigues Silva para composição de sua dissertação de Mestrado intitulada "Recolhimento e destinação de embalagens vazias de agrotóxicos em pequenos municípios brasileiros: o caso do município de Bom Repouso, MG". A mestranda se compromete a não revelar quaisquer informações pessoais presentes nas gravações, sendo constante apenas a citação de meu cargo de responsabilidade na Central de Recolhimento de Embalagens Vazias de Pouso Alegre .

Bom Repouso, 20 de novembro de 2014. 


\section{AUTORIZAÇÃO PARA GRAVAÇÃO E CITAÇÃO}

$\mathrm{Eu}$, inscrito sob o $\mathrm{CPF}$ autorizo a gravação da entrevista conduzida pela mestranda Mayra Rodrigues Silva para composição de sua dissertação de Mestrado intitulada "Gestão de embalagens vazias de agrotóxicos - Logística Reversa em pequenos municípios brasileiros: o caso do município de Bom Repouso, MG". A mestranda se compromete a não revelar quaisquer informações pessoais presentes nas gravações, sendo constante apenas a citação de meu cargo de responsabilidade no Sindicato dos Trabalhadores Rurais de Bom Repouso.

Bom Repouso, de outubro de 2015. 
